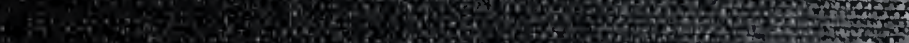
5 (2) c.5

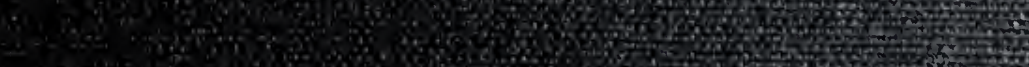

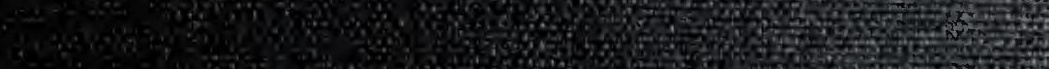

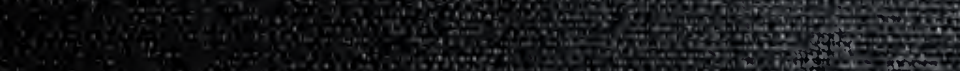

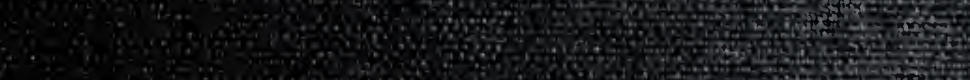

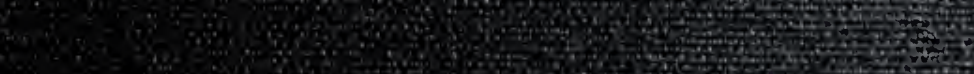
230.50 .

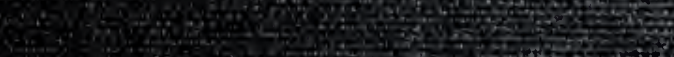

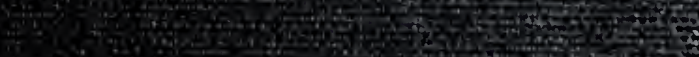
4. $x \quad 34$.

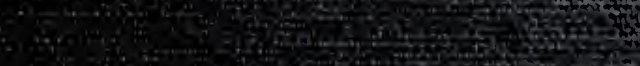

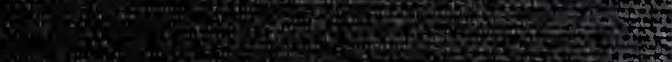
2. Sar.

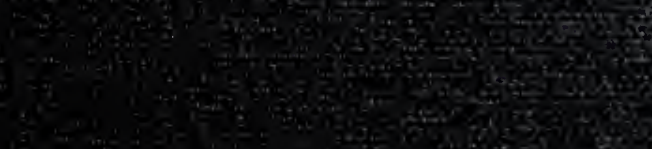

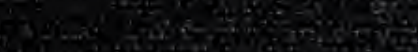
-

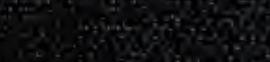

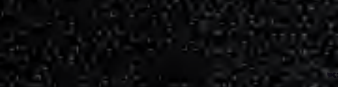

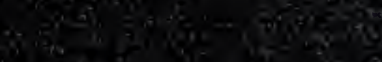
ix (⿻) Pexpos S. and

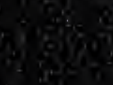
(4) wisent a

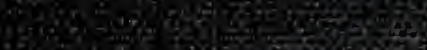

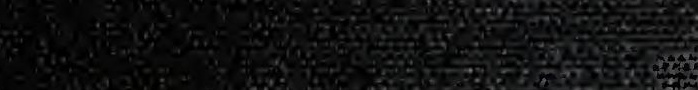
20090. (20.3. 2.0.

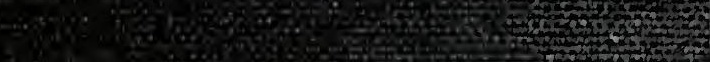
- 3 . -

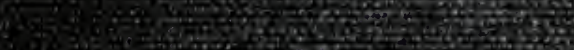

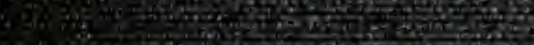

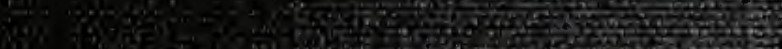

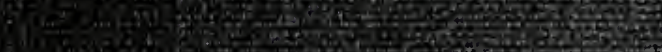

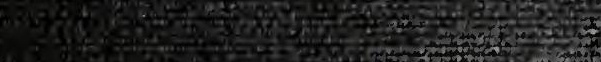
9.

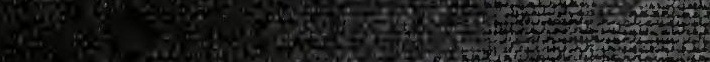

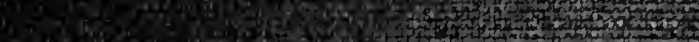

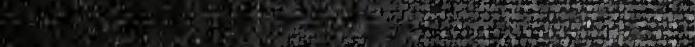

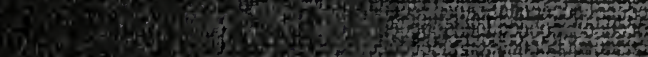


UNIVERSITY OF

ILLINOIS LIBRARY

AT URBAIVA-CHAMPAIGN

BIOLOGY

Min a warm 

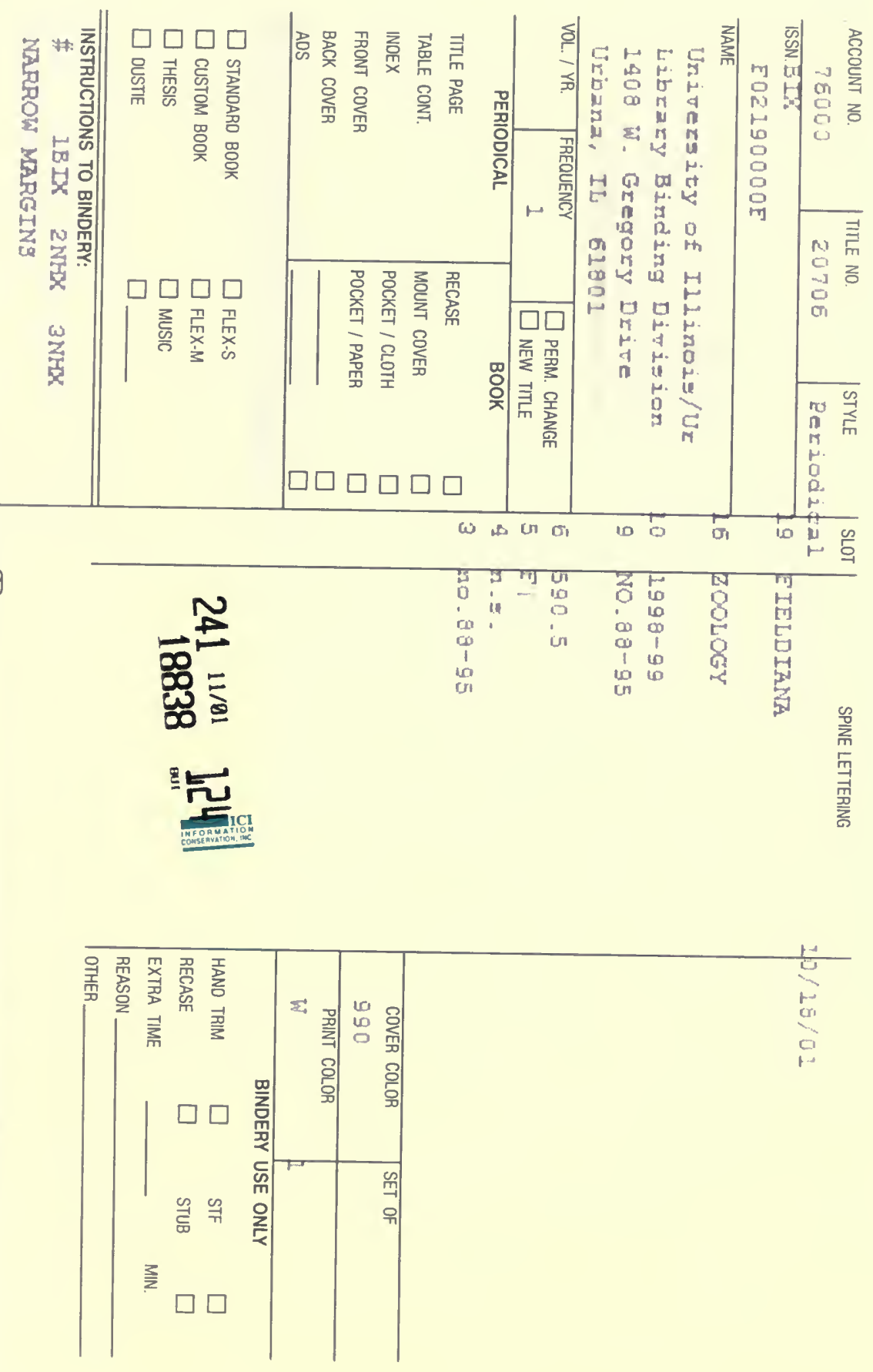



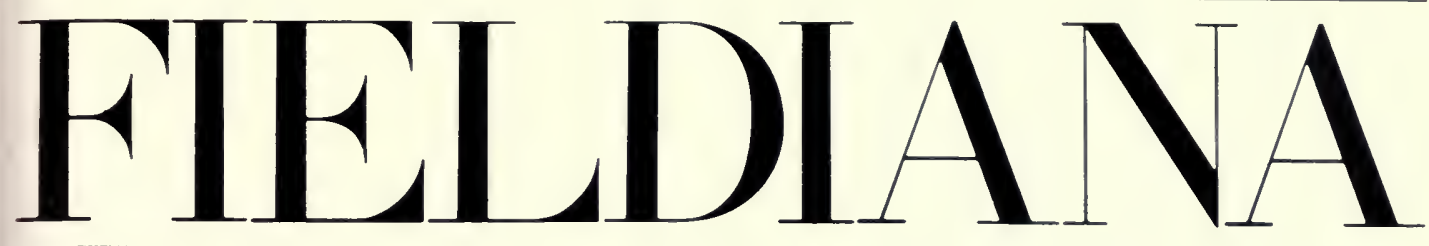

\section{Zoology}

NEW SERIES, NO. 93

Dromiciops gliroides Thomas, 1894,

Last of the Microbiotheria

(Marsupialia), with a Review of the

Family Microbiotheriidae

Philip Hershkovitz $\dagger$

\section{Curator Emeritus}

Division of Mammals

Department of Zoology.

Field Museum of Natural History

Roosevelt Road at Lake Shore Drive

Chicago, Illinois 60605-2496 USA

Accepted June 14, 1996

Published May 28, 1999

Publication 1502 
(C) 1999 Field Museum of Natural History

ISSN 0015-0754

PRINTED IN THE UNITED STATES OF AMERICA 
Dromiciops gliroides Thomas, 1894, Last of the Microbiotheria (Marsupialia), with a Review of the Family Microbiotheriidae 


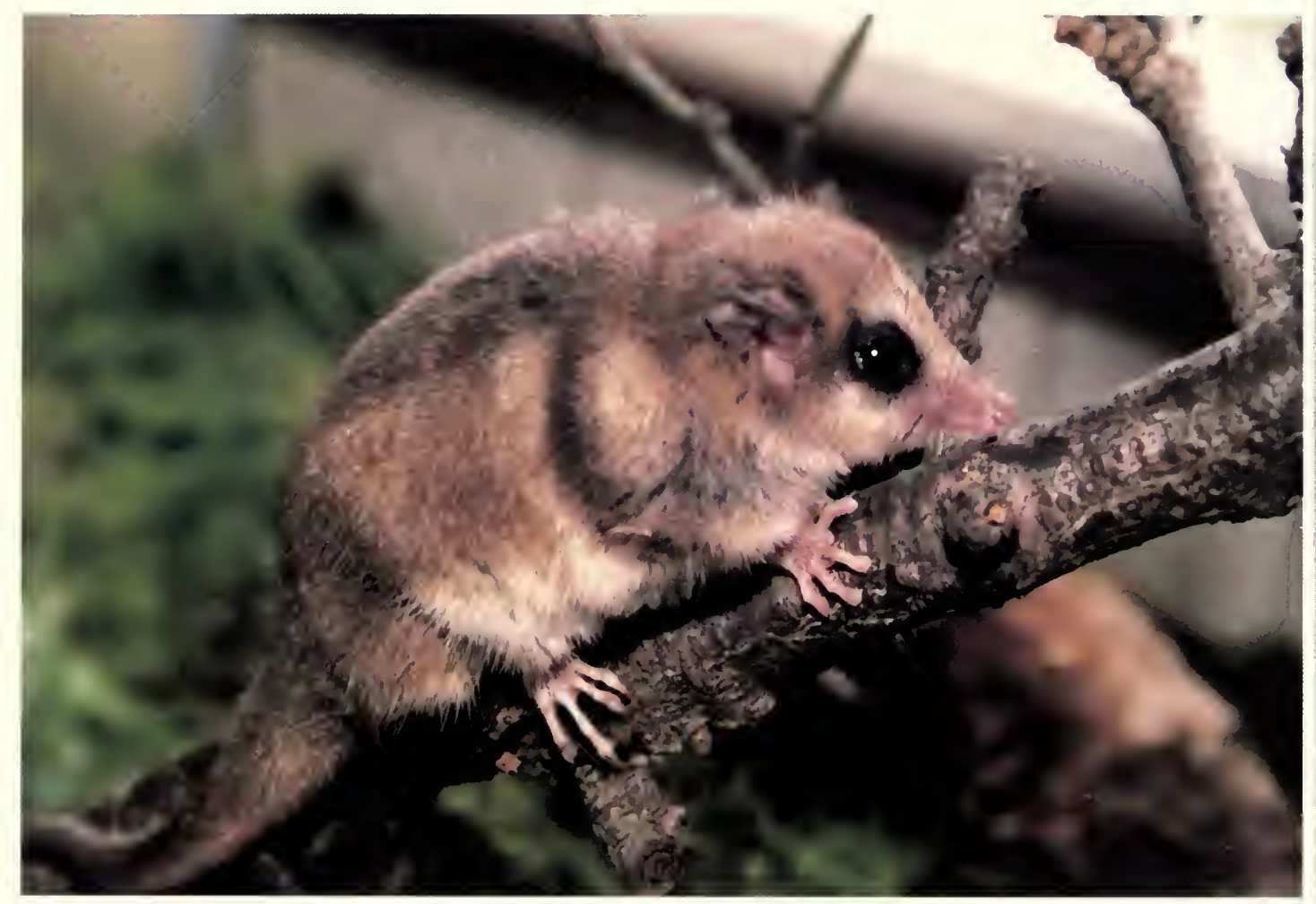

Dromiciops gliroides Thomas (Isla Chiloé, Chile). Photograph courtesy of Sr. Felipe Montiel Vera. 


\section{Table of Contents}

ABSTRACT

INTRODUCTION

Order Microbiotheria AMEghino, 1887 ,

COHORT MICROBIOTHERIOMORPHIA

AMEGHINO

BIOLOGICAL OrIGIN ............................ 5

GEOGRAPHIC ORIGIN ............................ 7

Weddellian Biotic Province of

ANTARCTICA

Weddellian LaNd Habitats .................. 7

WEDdELLIAN LaNd MaMmals .................. 8

RECORDED MICROBIOTHERES ..................... 9

BIOGEOGRaphy: The Nothofagus-

Chusquea-Microbiothere Association ... 10

Small Rodent Associates ................... 11

FAMILy MiCRobiotheriIDAE AMEGHINO ........ 12

Genus Dromiciops Thomas, 1894 .......... 12

Microbiotheriid Characters Distinctive

Among Marsupials ..................... 13

Subsidiary Characters ...................... 18

Epitome ..................................... 25

Dromiciops gliroides Thomas ............... 26

ACKNOWLEDGMENTS ............................ 56

ADDENDUM ................................... 56

GAZETTEER .................................. 56

LITERATURE Cited .............................. 57

\section{List of Illustrations}

Frontispiece: Dromiciops gliroides Thomas

Plate 1. Dromiciops gliroides Thomas

Plate 2. Nest and nestlings of Dromiciops gliroides Thomas

1. Geographic distribution of living Dromiciops

2. Odyssey of the MicrobiotheriaNothofagus-Chusquea association

3. Bamboo in upper and lower stories .......

4. Leaves of the bamboo Chusquea culeou

5. Mandibular symphyses of Dromiciops and Marmosa

6. Mandibular symphyses of various marsupials

7. Auditory bulla of Dromiciops, auditory bulla of a Microbiotherium

8. Posteroventral portion of Dromiciops cranium
9. Testis of Dromiciops ..................... 18

10. Rete testis sections ...................... 19

11. Rete testis of various marsupials ........ 20

12. Cloaca in Dromiciops and Thylamys .... 21

13. External ear of Dromiciops and Marmosa ................................... 22

14. Mammary field of Dromiciops ........... 23

15. Tarsal bones ............................... 24

16. Upper dental system of Dromiciops ..... 25

17. Fragment of left ramus of Adinodon pattersoni .................................. 26

18. Caecum of Dromiciops .................... 27

19. Geographic distribution of Dromiciops gliroides ................................ 29

20. Caudal fields of Dromiciops and Metachirus compared ..................... 30

21. Cheiridia of Dromiciops and Metachirus nudicaudatus ................. 31

22. Four types of spermatozoa .............. 36

23. Reproductive system in female and male Philander and female Dromiciops .. 38

24. Skull of Dromiciops ....................... 40

25. Diagrams of Dromiciops skull ........... 41

26. Auditory bullae ........................... 44

27. Transitional vertebrae ..................... 45

28. Thoracolumbar flexure ................... 46

29. Left upper and left lower tooth rows of Dromiciops, Philander, Caenolestes ..... 47

30. $\mathrm{p}^{2}, \mathrm{dp}^{3}, \mathrm{~m}^{1}$ in Dromiciops; $\mathrm{p}_{2}, \mathrm{dp}_{3}, \mathrm{~m}_{1}$ in Dromiciops; occlusal aspect of $\mathrm{p}_{2}$, $\mathrm{dp}_{3}, \mathrm{~m}_{1}$ in Dromiciops .................... 50

31. $\mathrm{p}_{1-2}, \mathrm{p}_{3}$ erupting, $\mathrm{dp}_{3}$ functioning, $\mathrm{m}_{1}$ in Philander

32. $p^{2}, p^{3}$ erupting, $d p^{3}, m^{1}, m^{2}$, pseudoquadritubercular $\mathrm{m}^{3}$............... 52

33. Karyotype of Dromiciops ................. 53

\section{List of Tables}

1. External, cranial, and dental measurements

2. Measurements of seminiferous tubules and rete testis

3. Postcranial skeletal measurements and proportions

4. Dental symbols ............................. 48

5. Sequence of dental eruption ............... 52

6. Dromiciops nests and occupants .......... 54 



\title{
Dromiciops gliroides Thomas, 1894, Last of the Microbiotheria (Marsupialia), with a Review of the Family Microbiotheriidae
}

\author{
Philip Hershkovitz $\dagger$
}

\begin{abstract}
The tiny Chilean and bordering Argentinian endemic Dromiciops gliroides Thomas, lone survivor of the South American Cohort Microbiotheriomorphia, is basal to all known marsupials. Indications are that the ancestral microbiothere may have originated in South America during the Late Mesozoic in a cool, humid, low-latitude biome dominated by a beech-bamboo (Nothofagus-Chusquea) plant association, the bamboo being its primary nesting material. A postulated worldwide climatic warming initiated a southward migration of cool-loving elements of the Southern Hemisphere. The philopatric microbiotheres evidently clung to their Nothofagus-Chusquea niche and nesting material as the association shifted from subequatorial into Patagonian and Antarctic latitudes. A climatic reversal during the Tertiary returned the Nothofagus-Chusquea-microbiothere association to Patagonian latitudes. An expanding arid scrub savanna farther north, however, halted the Nothofagus community shift in that direction. At the same time, habitat was being lost to the increasingly colder climate advancing from the south. Extinction followed. The most northern progression of the association was in the west, where rains intercepted by the rising Andes provided a favorable environment. The NothofagusChusquea-microbiothere association now survives in the cool, humid Valdivian region of Chile and its narrow Argentine extension as a relictual enclave sharply delimited by the warmer arid environment to the north and the colder, drier environment to the south.

The present ecogeographically restricted Cohort Microbiotheriomorphia is described and compared with its sister Cohort Didelphimorphia, which, by virtue of its adaptability, fecundity, and diversity, had dispersed into all continents. The narrow climatically controlled distribution and what little is known of the life history and anatomy of the single surviving microbiothere, Dromiciops gliroides, are reviewed.
\end{abstract}

\section{Introduction}

The monito del monte, Dromiciops gliroides Thomas (frontispiece; Plates 1, 2), a mouse opossum with a simian vernacular name, is the lone survivor of the South American marsupial family Microbiotheriidae Ameghino, 1887. The monito del monte and a dozen or so known extinct species of the same family compose the monophyletic Cohort Microbiotheriomorphia Ameghino. Together with Cohort Didelphimorphia Gill, 1872, it constitutes the Infraclass Marsupialia, also known as Metatheria. Reig (1955) was the first to recognize the relationship between the living Dromiciops and the extinct microbiotheriid marsupial then known only from the Miocene.

The Microbiotheriomorphia, with its single known family Microbiotheriidae, was reviewed by Marshall (1982), with attention given to cranial, dental, and external characters. The clade was treated as a family of Didelphoidea, its distinctive characters unperceived except for mention of small canine teeth. It has since been determined (Hershkovitz, 1992a) that microbiotheriids are monophyletic and must have arisen at some time before the divergence of didelphoids, 

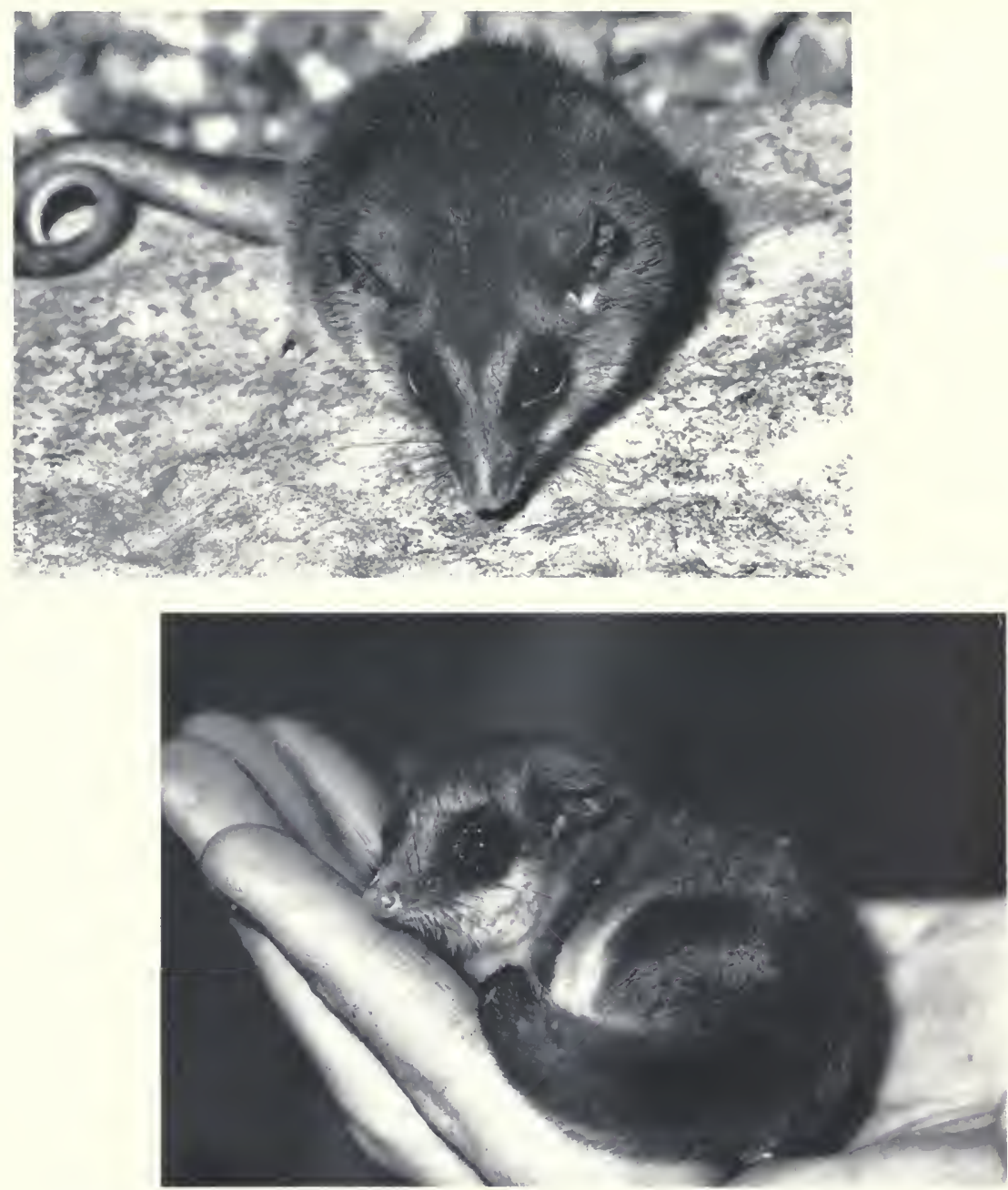

Plate 1. Dromiciops gliroides, natural size: top, note incrassate prehensile tail displayed by adult; bottom, same individual cupped in hand. Animal captured in Chile by Dr. Bruce Patterson and donated to the Chicago Zoological Society, Brookfield, Illinois. Photograph by Mike Greer; original photograph courtesy of the Zoological Society (reproduced from Hershkovitz, 1992a).

which are characterized by their distinctive staggered lower third incisor (Hershkovitz, 1995).

\section{Order Microbiotheria Ameghino, 1887, Cohort Microbiotheriomorphia Ameghino}

Distribution (Figs. 1-4)-PPRESENT: Cool, humid, dominantly Nothofagus-Chusquea forests of south central Chile, from the latitude of Concepción (ca. $37^{\circ} 00^{\prime}, 72^{\circ} 30^{\prime}$ ) to the southern border of Isla Chiloé (ca. $44^{\circ} 00^{\prime}, 72^{\circ} 00^{\prime}$ ), thence eastward into adjacent parts of Argentina in western Neuquén and southwestern Río Negro. PAST: Successively: Upper El Molino-Santa Lucia Formation, Cochabamba, south central Bolivia (Early Paleocene; see Marshall et al., 1995, for details); Itaboraían Formation in Rio de Janeiro, south-

Plate 2. A, Arboreal nest of Dromiciops gliroides constructed of moss and the leaves of bamboo (Chusquea culeou). B, Nestling. C, Young taken from back of mother. (Copied from photographs by Mann, 1958.) 

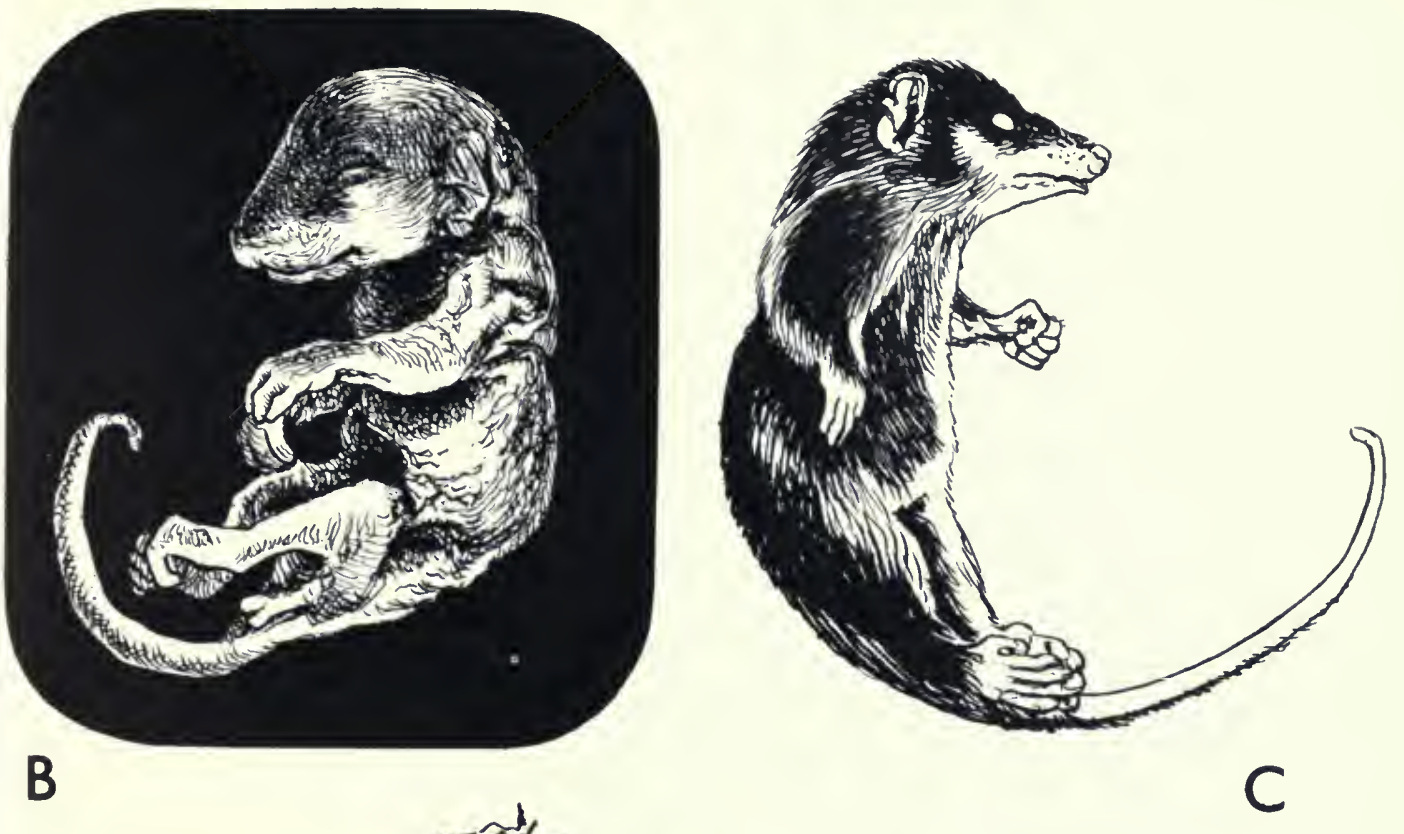

B

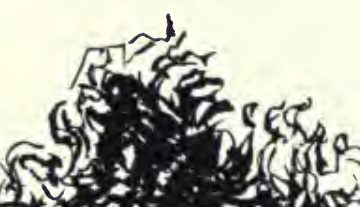
, sing, ( $\therefore<$ Sof

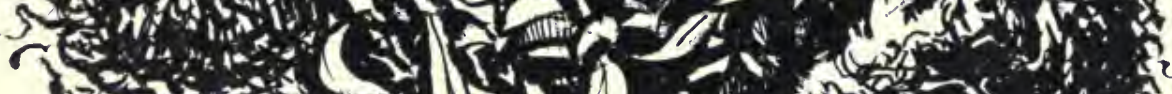

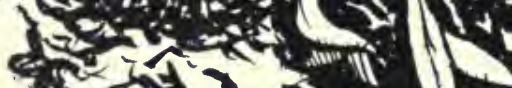

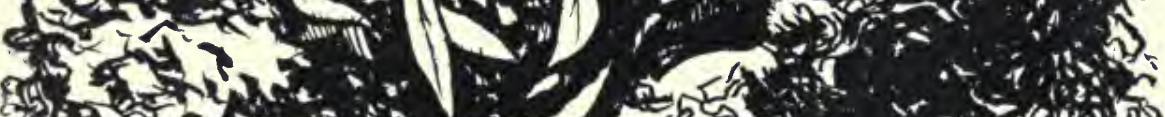

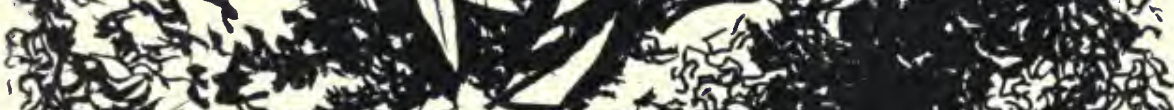
I

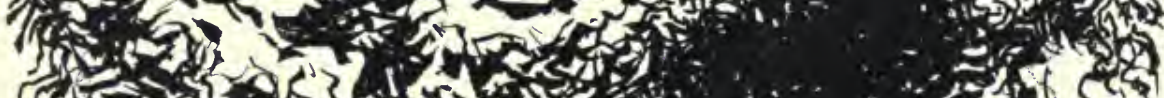

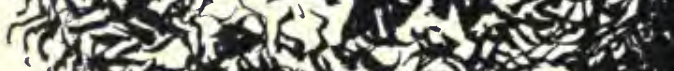
Shat If his

$$
f\left(\frac{1}{20}\right)_{A}
$$




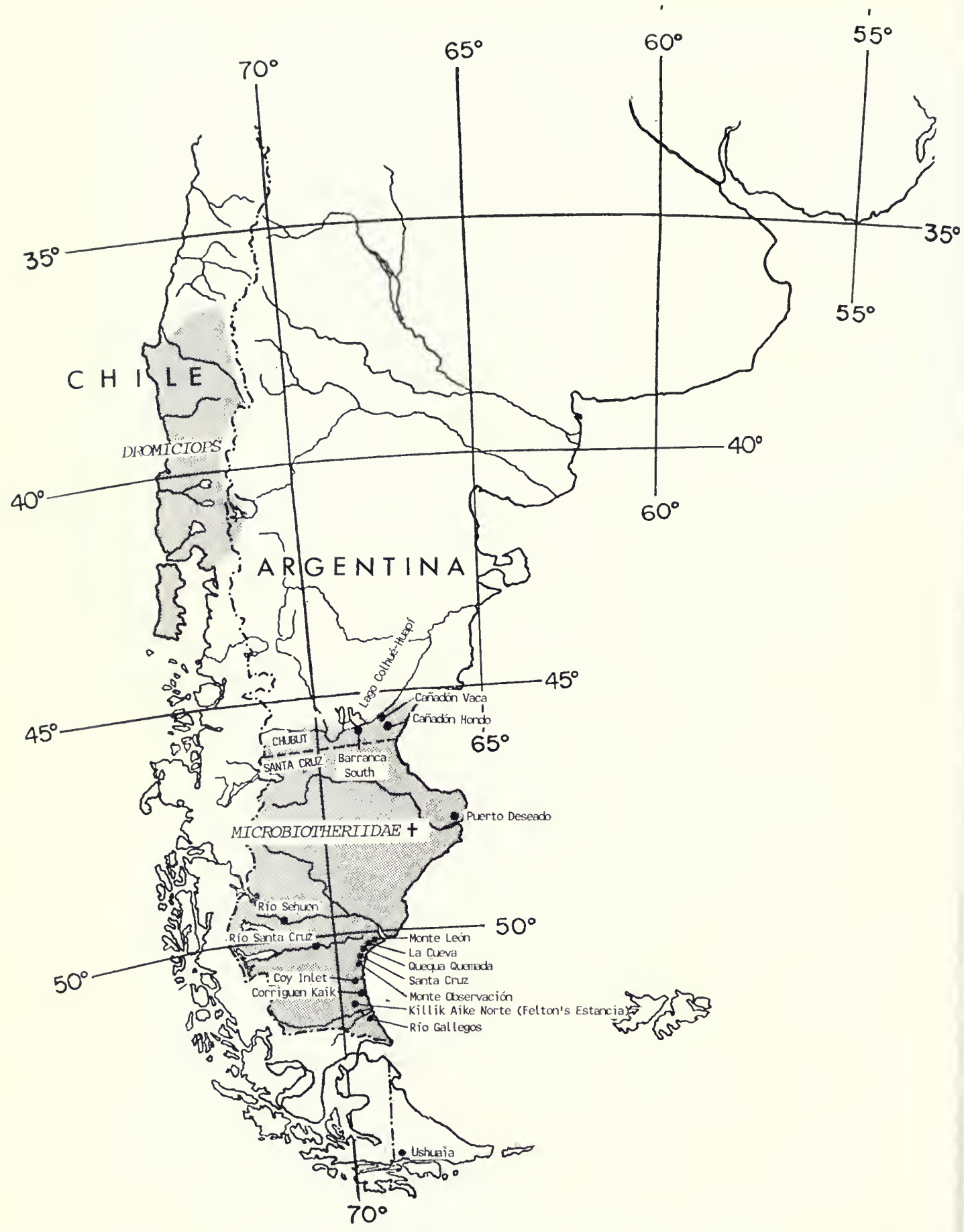

FlG. 1. Distributions of living Dromiciops gliroides in Chile and bordering Argentina (see Fig. 19, p. 29, for locality records, and p. 9 for names and ages of extinct Oligocene-Miocene microbiotheriids in southern Argentina). 


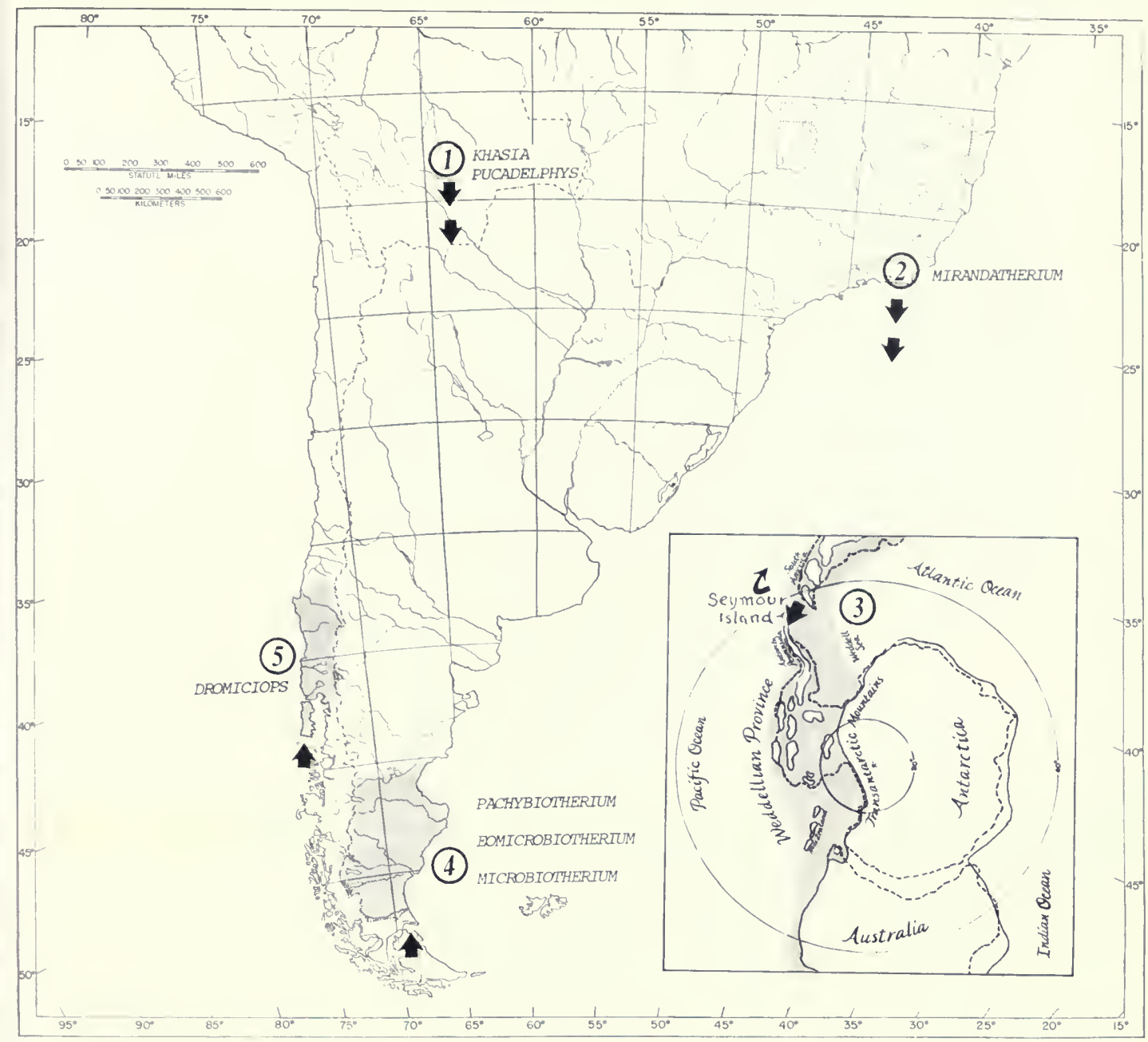

FIG. 2. Geoclimatic stages in the odyssey of the Nothofagus-Chusquea-microbiotheriid association in southern South America and Antarctica. Stage 1: South central Bolivia (Early Paleocene). Stage 2: São José de Itaboraí, Rio de Janeiro (Middle Palcocene). Stage 3: La Meseta Formation, Seymour Island, Antarctic Peninsula (Eocene). Stage 4: Reversion to southern Patagonia (Argentina) (Oligocene-Miocene), continuing into (Stage 5) central Chile (Tertiary-Recent). Arrows point to direction of migration with changing climates.

eastern Brazil (Middle Paleocene); Colhuehuapian and Santacrucian formations from Lago ColhuéHuapí ( $\left.46^{\circ} 30^{\prime} S\right)$ to Río Gallegos (51 $\left.36^{\circ} \mathrm{S}\right)$, Chubut and Santa Cruz provinces, Argentina (Oligocene. Miocene); La Meseta Formation, Seymour Island. Antarctic Peninsula, Weddellian Province, Antarctica (Eocene).

\section{Biological Origin}

Monophyletic Microbiotheriomorphia with its combination of prototherian-, metatherian-, and eutherian-like grade characters may have appeared in latest Jurassic or earliest Cretaceous. Its origin may have been from the same metatherian stock that later gave rise to Cohort Didelphimorphia, distinguished by the staggered $i_{3}$, precaudal cloaca, and other derived characters fully evolved by late Early Cretaceous (Hershkovitz, 1982, 1992a, 1995) but inferentially not before the appearance of the microbiotheriids, which lack these derived characters. The tree showing phylogenetic position and relationship of didelphoids (Hershkovitz, 1992a, p. 210) is subject to modification 


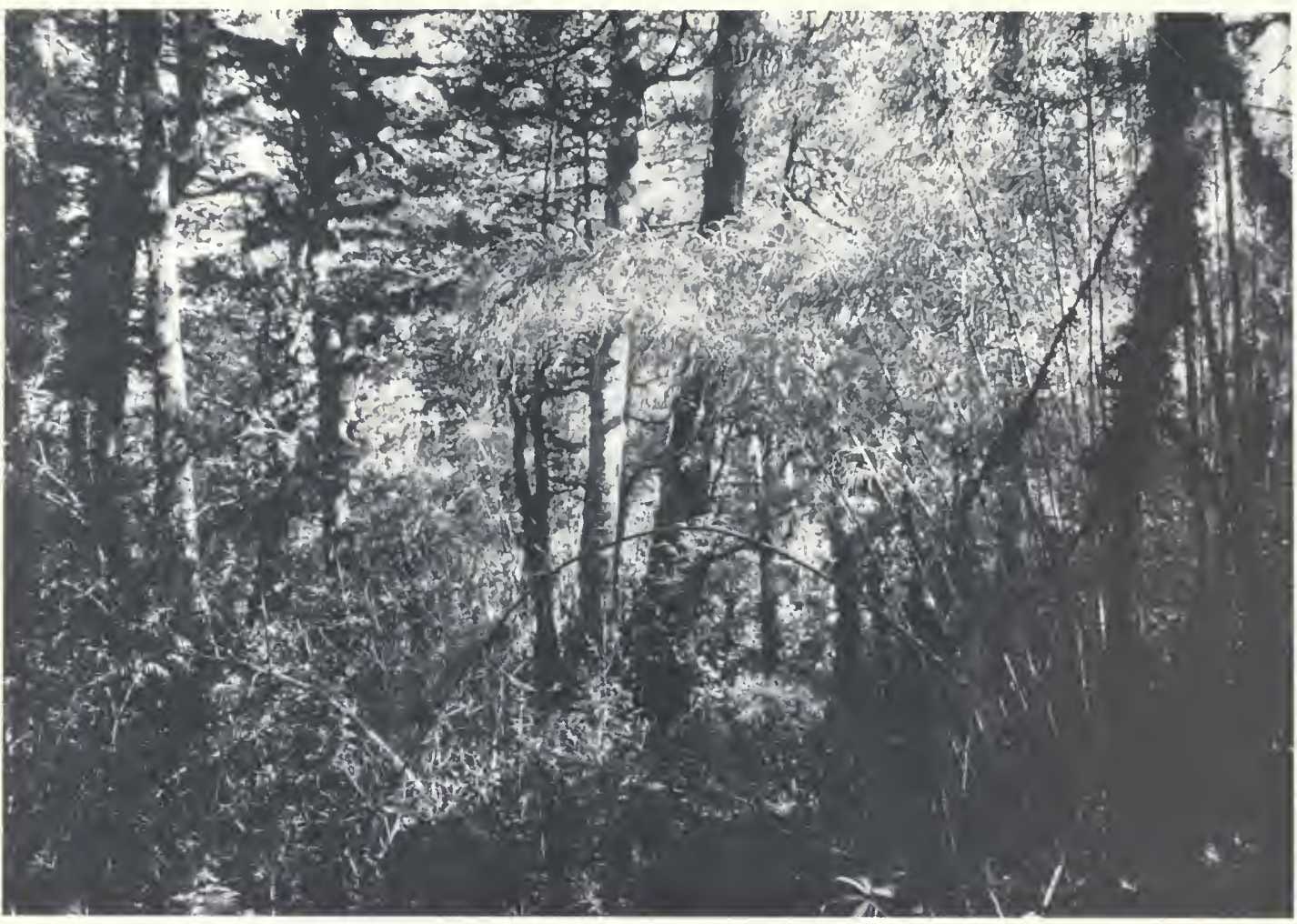

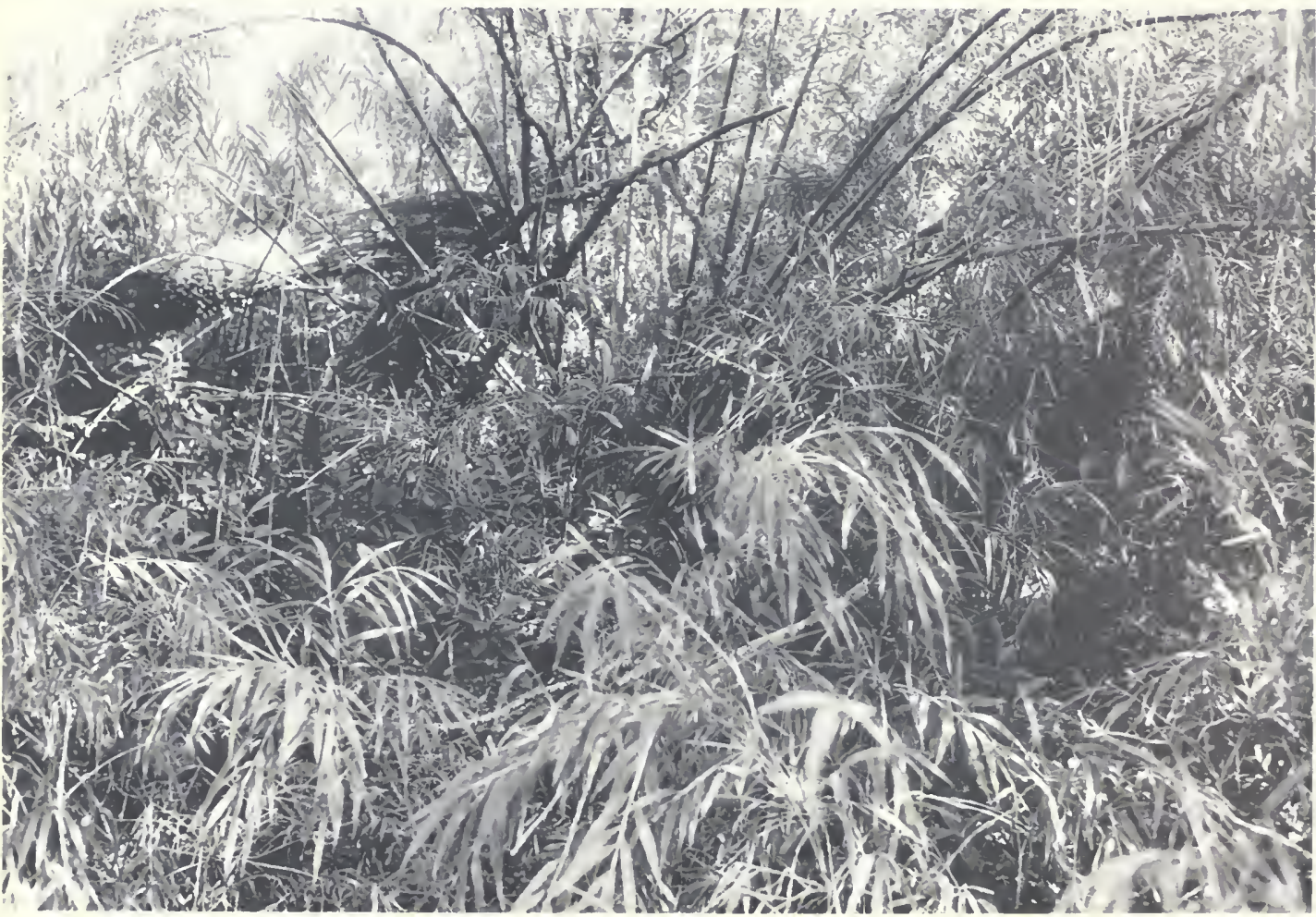


within a Metatheria perceived as independently differentiated from a therian stock.

\section{Geographic Origin}

The oldest known didelphoids are North American Albian age (late Early Cretaceous: Adinodon [Hershkovitz, 1995], Kokopellia [Cifelli, 1993], and Holoclemensia [Slaughter, 1968a,b]; see also Turnbull, 1995). Both the phylogenetically older microbiotheres and the geologically younger didelphoids are known as fossils from the Bolivian El Molino Formation of earliest Paleocene (Marshall et al., 1985, 1995; Marshall \& de Muizon, 1988). It has been argued that the earlier Albian age of some didelphoids presupposes a North American origin of marsupials, microbiotheres not having been distinguished at the time from the derived didelphoids. Microbiotheres, however, are unknown in North America. All locality records, whether of extant or known extinct microbiotheres, are from well south of the equator in South America, including one from the Antarctic Peninsula (Carlini et al., 1991; Goin \& Carlini, 1995). It appears, therefore, that the continent of marsupial origin is properly based on the phylogenetically basal South American or Weddellian microbiotheres and not the (tentatively) geologically older but phylogenetically younger North American didelphimorphs.

In my discussion of marsupial ankle bones and phylogeny (Hershkovitz, 1992a, p. 206), the habitat of the Microbiotheriomorphia was inadvertently given as North American. It should have been South American.

\section{Weddellian Biotic Province of Antarctica}

The Weddellian Paleogene-Cretaceous Biotic Province was distinguished by Zinsmeister (1976) on the basis of similarities between the late Cretaceous and Early Paleocene shallow-water molluscan faunas of Antarctica, Australia, southern
South America, New Zealand, and encompassed islands. The southern provincial border was determined as the Transantarctic Mountain front; the northern limit was said to coincide with the edge of the continental shelf, including southern Argentina and central Chile (map, Fig. 2, p. 5).

\section{Weddellian Land Habitats}

Forest-covered habitats within a temperate Antarctic zone such as the Meseta Formation of the peninsular Seymour Island (Fig. 2) were known to exist during Permian through Early Tertiary periods (Seward, 1914). Woodburne and Zinsmeister (1984, p. 935) note that the "presence of large $\operatorname{logs}$ (up to a meter in diameter), together with other plant debris indicates that the Antarctic Peninsula was still heavily vegetated during the Eocene [and that] preliminary analysis of the abundant palynomorph floras of the La Meseta Formation [of Seymour Island] indicates that conditions on the northern part of the Antarctic Peninsula were similar to present-day humid-temperature climates in Tasmania, New Zealand, and southern South America." Similar conclusions were reached by Doktor et al. (1996) from the plant and fish assemblages from the Eocene La Meseta Formation.

Dettman (1989, p. 89), in her paper "Antarctica: Cretaceous cradle of austral temperate rainforests?" observed that "fossil evidence from Antarctica and closely associated regions in the Cretaceous southern Gondwana assembly confirms that Antarctica was a Cretaceous originator and dispersal region of certain elements of today's southern hemispheric humid and prehumid forests. Antarctica origins are indicated for the fern Lophosoria, podocarp gymnosperms, and several lineages of the Proteaciae; migration to their present regions of distribution was probably step-wise. Antarctica also served as a Cretaceous dispersal corridor for other angiosperms represented today in mid to low latitude austral regions."

Fig. 3. Top, bamboo (Chusquea sp.) in second growth forest of La Petard State Park, Iporanga, São Paulo. Bottom. Chusquea in lower story clearing of La Petard State Park, São Paulo. Microbiotheriids are not known to have occurred in São Paulo (see map, Fig. 1, p. 4). Photographs by Barbara Brown, December 1989. 

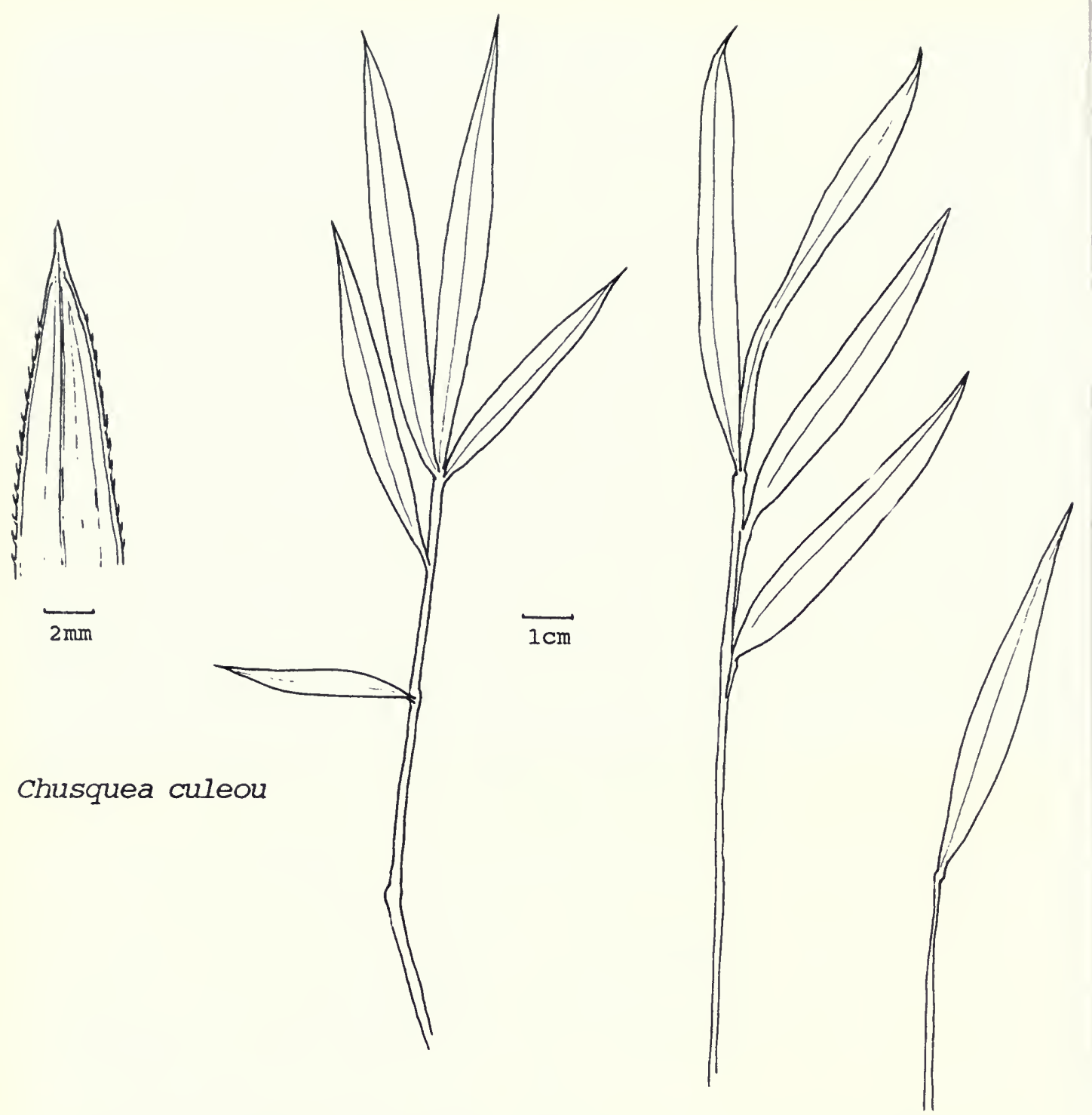

Fig. 4. Leaves of the bamboo Chusquea culeou, used by Dromiciops for weaving its waterproof nest.

\section{Weddellian Land Mammals}

The first land mammal known from Antarctica, described by Woodburne and Zinsmeister (1984), is the polydolopoid marsupial Antarctodolops dailyi from the Late Eocene of Seymour Island, northern Antarctic Peninsula. The degree of biological differentiation from its nearest South American relative suggested "a late Cretaceous presence of marsupials in Greater Antarctica and their isolation in Australia by whatever means by the close of that period." In the opinion of Wood- burne and Zinsmeister (1984, p. 933), "the Seymour Island polydolopids represent a sample of a mammal population that likely had been endemic to the region for about $10 \mathrm{Ma}$, and had actually dispersed from South America at about $50 \mathrm{Ma}$, when the group was most abundant and diverse there.... We also conclude from the number of specimens represented, and geological evidence ... that the entry of polydolopids into Antarctica reffects waif dispersal via an archipelago between southern South America and the Antarctic Peninsula rather than a continuous land connection." 
The overall evidence suggests, continue Woodburne and Zinsmeister (1984, p. 942), that "marsupials must have been present on Antarctica sometime from the Late Cretaceous to the Eocene. The Oligocene and younger marsupials on Australia ... require an earlier - probably a much earlier (because of their diversity in the Oligocene and Miocene)-ancestor there or in a closely neighboring place. That place was Antarctica from at least $80 \mathrm{Ma}$ and, diminishingly, to about 38 Ma ago."

The recovery of a ground sloth "Megatherioidea" reported by Carlini et al. (1991, p. 15) added another order of South American mammals to the known Late Eocene fauna of the La Meseta Formation. Other remains in the same Seymour Island Formation and underlying Cross Valley members of the Sobral Formation (Paleocene) reported by Carlini et al. (1991) are a "probable microbiotheriid, polydolops, birds and plants." Isolated teeth of the unique South American deerlike "ungulates" representing the families Theridodontidae and Trigonostyliodae, recovered by Bond et al. (1990, p. 3) from the Seymour Island Formation, are the first eutherians known for the region.

Discovery by Pascual et al. (1992a,b) of a platypus (Monotremata) tooth in sediments of the Banco Negro Inferior $\left(45^{\circ} 30^{\prime} \mathrm{S}, 67^{\circ} 11^{\prime} \mathrm{W}\right)$, Chubut Province, southern Patagonia or within the Patagonian Terrane, a subset of the Weddellian Province, added another biogeographic dimension to the region.

\section{Recorded Microbiotheres}

The 13 recorded extinct species, including 2 undescribed (types, tentatively and dubiously assigned individuals), and 1 living species, distributed among the 7 genera, are listed below (and in Fig. 2). References to original descriptions, taxonomies, synonymies, geographic data, and figures of teeth and bone fragments of the first 8 species are from Marshall (1982). The determinations of the fossils as microbiotheres are accepted as tentative from Marshall (1982, 1987). Marshall and de Muizon (1988), and Marshall et al. (1990). Description of Pucadelphys andinus is from Marshall and de Muizon (1988). Discussion of the genus as a microbiothere is based on data from Marshall et al. (1995).

Some discrepancies in earlier reports may have crept in. Compare, for example, lower canines of numbers 2 and 6 in Marshall (1982, p. 47). Identification of number 2 may be equivocal. 1t carries the same name and registry number, PU 15038 , of the figured auditory region of Microbiotherium tehuelchum (Marshall, 1982, p. 30), which is a true microbiothere. Neither it nor the aforementioned figured canine belong to the same taxon or to the neotype of $M$. tehuelchum Ameghino, 1887 (MLP36). The identification of Mirandatherium, although not queried, requires reexamination. The Pediomyinae, generally classified as microbiotherioid (cf. Marshall et al., 1990), are not so regarded here. The named forms follow.

Microbiotherium acicula Ameghino, 1891 (Marshall, 1982, p. 12)-Santacrucian (Monte Observación), Santa Cruz Province, Argentina (Miocene).

Microbiotherium patagonicum Ameghino, 1887 (Marshall, 1982, p. 14)-Santacrucian, Santa Cruz Province, Argentina (Miocene).

Microbiotherium divisum Ameghino, 1902 (Marshall, 1982, p. 22)-Colhuéhuapian beds, at the Barranca south of Lago Colhué-Huapí, Chubut, Argentina (Miocene).

Microbiotherium tehuelchum Ameghino, 1887 (Marshall, 1982, p. 26)-Santa Cruz Formation (Corriquem-Kaik; Quequa-Quemada; La Cueva; Monte Observación; Killik Aike) Santa Cruz, Argentina (Miocene).

Microbiotherium praecursor Ameghino, 1898 (Marshall, 1982, p. 19) - "Cretaceo inferior." Age and locality unknown.

Microbiotherium gallegosense Sinclair, 1906 (Marshall, 1982, p. 35)-Santa Cruz Formation, $\mathrm{N}$ bank Río Gallegos, Santa Cruz, Argentina (Miocene).

?Pachybiotherium acclinum Ameghino, 1902 (Marshall, 1982, p. 61)-Colhuéhuapian beds, probably Barranca, Chubut, Argentina (Miocene)-microbiotheriid identity questioned by Marshall (1982, p. 63).

?Eomicrobiotherium gaudryi Simpson, 1964 (Marshall, 1982, p. 58)-Barranca, S Lago Colhué Huapí, Chubut, Argentina (Miocene)-The genus reviewed by Marshall (1982, p. 57) includes a second, unrevised species, E. gutierrezi del Corro, but the microbiotheriid affinities of the genus are problematic (Marshall, 1982, p. 59).

Pucadelphys andinus Marshall and de Muizon, 1988-Tiupampa local fauna, El Molino- 
Santa Lucia Formation, Cochabamba, Bolivia (Early Paleocene).

Khasia cordillerensis Marshall and de Muizon, 1988-Tiupampa local fauna, El Molino Formation, Cochabamba, Bolivia (Early Paleocene).

Mirandatherium alipioi Paula-Couto, 1962São José de Itaboraí, Rio de Janeiro, Brazil (Middle Paleocene); Marshall (1987, pp. $114,137,148)$.

Microbiotherium sp., Antarctica, La Meseta Formation, Seymour Island, Antarctic Peninsula, Late Eocene. Carlini et al. (1991); Goin and Carlini (1995).

Dromiciops gliroides Thomas, 1894-Isla de Chiloé; Los Lagos, Central Chile (Recent).

Among 169 newly recovered dental specimens of Colhuéhuapian-Santacrucian age, Bown and Fleagle (1994) distinguished the teeth of three species of the genus Microbiotherium from Oligocene and Miocene Patagonian rocks. The material included a new species of Colhuéhuapian Microbiotherium, closest in size to $M$. praecursor; a new Santacrucian Microbiotherium from the Pinturas Formation, intermediate in size between $M$. acicula and $M$. praecursor; and the common Pinturas and Santacrucian M. tehuelchum.

Four partial skeletons and an extra skull of $P u$ cadelphys andinus Marshall and de Muizon (1988) recovered from the Santa Lucía Formation of Tiupampa, about $95 \mathrm{~km}$ SE of Cochabamba $\left(65^{\circ} 35^{\prime} \mathrm{W}, 18^{\circ} 02^{\prime} \mathrm{S}\right)$, Cochabamba Department, south central Bolivia, were studied by Marshall et al. (1995). The geochronological position had previously been, and continues to be, referred to as the El Molino Formation.

Skeletal measurements provided by Marshall et al. (1995, p. 156) reveal Pucadelphys andinus to be relatively small, comparable in size to living caenolestids, marmosids, and the microbiothere Dromiciops gliroides. Cranially, Pucadelphys, with its more or less evenly proportioned skull, resembles Dromiciops as contrasted with the long rostrate caenolestid and narrowly triangulate marmosid skulls. Notwithstanding, caenolestids, like Pucadelphys, but unlike the others, are terrestrial, non-prehensile-tailed, and locomotorily similar. Nevertheless, phylogenetic, morphological, and behavioral comparisons and alignments of Pucadelphys made by Marshall et al. (1995) were with the least likely, most derived, and unrelated, staggered-toothed didelphoid Didelphis.

\section{Biogeography: The Nothofagus- Chusquea-Microbiothere Association}

Knowledge of living microbiotheres and nesting preferences indicates that the habitat of Dromiciops is restricted to the Nothofagus-Chusquea association of central Chile and bordering Argentina. Fossil evidence suggests that habitat preference of Dromiciops may have changed little in time. The fossils also record the latitudinal translations experienced by microbiotheres concomitant with the climatic shiftings of their nearly obligate Nothofagus-Chusquea-dominated habitat (Figs. 2-4).

The oldest known microbiotherians are from the El Molino Formation in Tiupampa, Cochabamba, Bolivia (Marshall \& de Muizon, 1988, p. 23; Marshall et al., 1995), now regarded as Early Paleocene. The next chronological record of microbiotherian occurrence is the mid-Paleocene Itaboraían of Rio de Janeiro, southeastern Brazil. This suggests a climatic change that shifted the Bolivian Nothofagus-Chusquea biome with its microbiotheres to the more southern or possibly then cooler latitudes of coastal Rio de Janeiro. Continuation of the warming trend southward led the Nothofagus-Chusquea-microbiothere association into Antarctica during the Eocene (Carlini et al., 1991; Goin \& Carlini, 1995) and led to the extinction of the Itaboraían species of the lower latitudes.

A climatic reversal brought freezing temperatures into Antarctica, ending the southward advance of the Nothofagus-Chusquea-microbiothere association and shunting it back into the warmer Patagonia of the then Oligocene-Miocene. The northward trend, however, was restrained by the more rapidly advancing arid scrub savanna arriving from the north, and habitat loss to the falling temperatures moving in from the south. Rains intercepted by the western versant of the rising Andes provided scope for continuation of the northward trend of the Nothofagus-Chusquea-microbiothere association into the Valdivian region of Chile and bordering parts of western Argentina during the Neogene. Continued favorable conditions at least locally into the Quaternary allowed the association to persist as a relict of the once cool, humid Tertiary Antarctic climate (Fig. 2). The Tertiary microbiotheres east of the Andes in southern Argentina disappeared as their special habitat gave way before the advancing aridity of the north and the cold climate of the south.

The Chilean-Argentine habitat of surviving 
Dromiciops, shown juxtaposed against that of the extinct Tertiary Argentine microbiotheres (map, Fig. 1), documents the geographic positions of the latest climatic shift of microbiothere habitat.

Mammalian survivors of what had been a rich Late Cretaceous-Tertiary Weddellian mammalian fauna are monotremes, the diversified American didelphoids, their Australian descendants, and the microbiothere line that led to Dromiciops gliroides. The latter is now confined to its shrinking man-endangered habitat in the cool, humid Valdivian Nothofagus-Chusquea forests of Chile and adjacent Argentina.

The climatic changes described above have been inferred from the stepwise shifts of habitat and fauna that might have begun north of and earlier than the time of the El Molino Formation in Bolivia. Fossil records support the reconstructions. The climatic shifts appear to be in rough agreement with latitudinal paleotemperature reconstructions by Frakes et al. (1994). The philopatric microbiotheres, linked to their NothofagusChusquea association, moved with it first southward, then back northward.

The ecologically based reconstruction by Pascual and Juaraguizar (1990, pp. 23-60) of changing climates and evolving vertebrate faunas of the southern half of South America and northwestern Antarctica throughout the Cenozoic is panoramic in scope. Didelphimorphs are accorded prime treatment but microbiotheres are not mentioned. A report by A. K. Pearson et al. (1994) on the biology of the bamboo Chusquea culeou of the Dromiciops-Nothofagus-Chusquea association is relevant to the subject. The pertinent parts are summarized below.

The groves of Patagonian bamboo, Chusquea culeou (Fig. 3), used by Dromiciops gliroides for habitat, and its bamboo leaves (Fig. 4) for nest construction, were studied for over 7 years by A. $\mathrm{K}$. Pearson et al. (1994), mostly in the Parque Nacional Nahuel Huapí in southwestern Argentina. The park and the region westward into the same latitudes of Chile to the coast and Isla Chiloé include many known Dromiciops habitats.

According to A. K. Pearson et al., three species of bamboo occur in the Argentine national park. Only Chusquea culeou is widely distributed. It occurs between $35^{\circ} \mathrm{S}$ and $47^{\circ} \mathrm{S}$. In Argentina, it covers a narrow band along the eastern Andean slopes of the Provinces of Neuquén. Río Negro, and northern Chubut, or coincident with the $\mathrm{Ar}$ gentine portion of the Dromiciops range. According to the authors (Pearson et al., 1994, p. 94) the
Nahuel Huapí Park's glacier-carved valleys are covered by

great native forests dominated by beech trees of the genus Nothofagus, with bamboo as a major understory component. Although man has had relatively little impact on these forests, glaciers, avalanches, mudslides. voleanic ashfalls and fires have all influeneed the distribution of the beech trees and the bamboo. Precipitation also has had an effect: bamboo is more abundant in the wet, mild climate near the Chilean border (over 4000 $\mathrm{mm}$ annual precipitation), and disappears toward the drier. colder eastern edge of the park $60 \mathrm{~km}$ away $(60) \mathrm{mm}$ annual precipitation). Cliusquea grows and thrives near Lago Nahuel Huapí (elevation $760 \mathrm{~m}$ ), where mosı precipitation falls as rain, but is also found up to $1450 \mathrm{~m}$.

It occurs both in pure stands in the open as well as beneath the dense canopy of Nothofagus forests.

The foregoing is, in effect, a description of the ecological niche of the philopatric Dromiciops.

\section{Small Rodent Associates}

Small mammals observed by A. K. Pearson et al. (I994, p. 118) frequenting the Chusquea culeou thickets in the Argentine Parque Nacional Nahuel Huapí include the mouse Irenomys tarsalis (Sigmodontinae), one of which they witnessed "shinny up bamboo culms and climb about in the foliage. Dromiciops australis [they observed] . . . uses bamboo leaves to construct its spherical nest. A variety of small rodents eat the underground rhizome buds and emerging shoots of C. culeou, among them Abrothrix longipilis, Aconaemys fuscus, Irenomys tarsalis, Auliscomys [= Loxodontomys $]$ micropus and Ctenomys mendocinus." A. K. Pearson et al. (1994) cited O. P. Pearson (1983) for the rodents. The long vegetative phase of the Chusquea culeou, more than 54 years before seeds are produced, eliminates the bamboo as a regular source of food for Dromiciops. The delayed production of bamboo seeds when it comes culminates in an explosive increase of mice. for which I had proposed the Spanish ratada (Hershkovitz, 1962, pp. 42, 277).

Microbiotheres may never have been abundant or widely dispersed from their Nothofagus-Chusquea association in the Southern Hemisphere. Insofar as known, differentiation at any time was restricted to no more than one to a few species. the genera questionable. In sharp contrast, the hardy, adaptable, prolific, speciose didelphimorphs spread in all directions, populated three continents, and experimented in the other three. 
REMARKS-Resemblances between Dromiciops and living Australian marsupials noted by Dyzenchauz et al. (1993, p. 82) must be attributed to retention of shared primitive characters such as a karyotype of 14 chromosomes or presumed single-headed sperm. There is no positive evidence that microbiotheres originated or ever lived in Australia, much less that "Microbiotherium dispersal would likely have been from rather than to Australia" (Kirsch et al., 1991, p. 10465). Marsupials and placentals were unknown in Australia before the Eocene (Archer, 1993, p. 8). Long before that, in the latest Cretaceous or earliest $\mathrm{Pa}$ leocene, microbiotheres were disporting in Bolivia (Marshall \& de Muizon, 1988). Furthermore, Australian marsupials are derived from staggered lower third incisor didelphoids (Hershkovitz, 1982, 1995), not from microbiotheriids. Szalay's $(1982 \mathrm{a}, \mathrm{b})$ postulate that microbiotheriids together with all Australian marsupials form a monophyletic clade based primarily on ankle bone morphology does not agree with the data (cf. Hershkovitz, 1992a).

\section{Family Microbiotheriidae Ameghino}

\section{Genus Dromiciops Thomas, 1894}

TYPE SPECIES-Dromiciops gliroides Thomas, 1894.

The scenario of land mammal dispersal among South America, Antarctica, and Australia in the Late Cretaceous to Early Tertiary epochs, described by Woodburne and Case (1996), is based on a review of paleontological, phylogenetic, geophysical, and climatic evidence. They regard the Microbiotheriidae as australidelphian and dating from 63 Ma. They ask (1996, p. 138), without offering a solution, "to what order of Australian marsupials do microbiotheriids exhibit a special relationship?" The answer is, none. Microbiotheriids are not Australian. There is absolutely no evidence that microbiotheriids occur on that continent, or ever did. Their appearance in South America predates the arrival of any marsupials in Australia (Archer, 1993). Recorded similarities between Dromiciops gliroides and some species of Australian marsupials and eutherians must be attributed to parallelisms, convergences, or common retentions of primitive marsupial or therian characters.

The Woodburne and Case arguments for pin- ning microbiotheres in Australia are based primarily on the erratic hypothesis of ankle bone morphology (Szalay, 1982). Nevertheless the staggered $i_{3}$ as a significant phylogenetic marker. separating didelphimorphs and microbiotheriids appears to have been recognized by Woodburne and Case (1996).

Woodburne and Case's (1996, p. 142) exposition of their stand is summarized in their words:

Hershkovitz (1982, $1992[a], 1995)$ posits that Dromiciops, and by inference all microbiotheres, are more primitive than all other marsupials based on the lack of a staggered $\mathrm{i} 3\left[=\mathrm{i}_{3}\right]$. Hershkovitz (1995) proclaims that didelphoids are (a) much older than commonly considered as based on other features, such as a V-shaped centrocrista (upon which he does not comment), but also that the members of this group are plesiomorphic in having this trait (p. 160, no. 5) [see my reply, pp. 14, 16, to their egregious perversion of my statements]. Other than not having a staggered $i 3\left[=\mathrm{i}_{3}\right]$, there is nothing in Hershkovitz (1995) to suggest that microbiotheres are more primitive than all other marsupials. Pending further evidence, the [DNA] results of Springer et al. (1994, 1996 [in press]) and Retief et al. (1995) are followed here, i.e., that Dromiciops is rooted within the Australidelphia, rather than being the sister taxon of all marsupials.

The DNA-DNA hybridization studies of Westerman and Edwards (1991), showing a trichotomy of divergence between microbiotheres, didelphids, and dasyurids, were not considered but are no less speculative.

Although Woodburne and Case cited Hershkovitz, 1992a, they failed to note that lower incisor orientation is but one of a number of distinctive features described. Those features show that microbiotheres must have arisen at a time before those archaic or unique external, cranial, and dental characters seen only in Dromiciops had disappeared, were disappearing, or most likely were never present in other fully developed marsupials. They are among the basic therian characters that absolutely and decisively separate Dromiciops (the only known complete microbiotheriid) from all other marsupials. Any one of those cranial, dental, or external characters mentioned and numbered 1 to 7 below, invalidates the postulate that Dromiciops or a Dromiciops-like morphotype is or was near kin to Australian didelphimorph marsupials and their American originators. 


\section{Microbiotheriid Characters Distinctive Among Marsupials}

\section{Four lower incisors evenly spaced in Dromi- ciops (Figs. 5, 6)}

The maximum $\frac{5}{4}$ incisor formula of marsupials is believed to have been derived from a $\frac{5}{5}$ formula. Loss of the first lower incisor is attributed to contraction of the lower jaw at the birth of the earliest metatherian or ancestral form (Hershkovitz, 1982, p. 195) or may have been inherited directly from the ancestral therapsid. The remaining four incisors are not crowded in microbiotheriids.

The evolutionary sequence of mandibular contraction in marsupials, Dromiciops excepted, caused further crowding and elimination of additional lower incisors (cf. Marshall et al., 1990, p. 466). The contraction in didelphoids, dasyurids, and others forced the root of the numerical second lower incisor, or phylogenetic third, out of line with adjacent incisors (Figs. 5, 6). An upgrowth of the alveolus on the buccal side of the staggered tooth appears as a buttress. Attenuation or elongation of the mandibular body reduced or eliminated the staggered condition in many Australian marsupials. The condition is discussed and figured by Hershkovitz (1992a, p. 200; 1995).

Uncrowded four lower incisors are qualities of Dromiciops and other known microbiotheriids. The condition may be directly derived from therapsids with upper incisive formulae of the premaxilla ranging from 8 to 4 ; other shared therapsid traits are rounded incisive arch, short mandibular symphysis, and the presphenoidal sagittal crest.

2. Symphysis menti and lower incisive arch of Dromiciops and Marmosa (Figs. 5, 6)

"The incisive arch of Dromiciops is rounded, the mandibular symphysis shallow and extends back to a line between $i_{4-5}$, sometimes between $\mathrm{i}_{5}$-c. In all other marsupials examined, the arch and symphysis are angular the latter terminating behind at a line between lower canine and premolars.... In eutherians, the symphysis also extends back to a line between lower canine and premolars but .... dental formulae and diastemata of eutherians and marsupials are different with dental points of reference not strictly comparable....

"The short Dromiciops symphysis menti [is] not matched in any other living mammal" (Hershkovitz, 1992a, pp. 201, 202, Pl. X) but is com- monplace among reptiles, particularly therapsids (cf. Romer. 1966, p. 182), where it is often correlated with rounded incisive arch and the basicranial sagittal presphenoidal crest. All appear to be plesiomorphic features.

3. Entotympanic bone component in auditory bullae of Dromiciops and Microbiotherium (Fig. 7)

The earliest known marsupial auditory bulla is that of the Tiupampa microbiothere Pucadelphys andinus (Marshall \& de Muizon, 1995). The bulla is of the tripartite type (Hershkovitz, 1992b, p. 25, Fig. 10), with the hiatus between alisphenoid and petrous wings of the bulla. The Dromiciops bulla is a large, highly derived, inflated globe composed of the tympanic wing of the alisphenoid bone, the joined tympanic wing of the petrous bone, a greatly pneumatized mastoid bone with the mastoidal process absorbed, a narrow lamina of the basisphenoid bone, and a sutured ventromedial bone between alisphenoid and petrous wings identified as "entotympanic," an element not present in any other marsupial. The bone is not homologous with the so-named entotympanic bones of eutherians. That of Dromiciops is interpreted as an adventitious element that, during the course of auditory bullar evolution, filled the midventral and medial gap before the approximating alisphenoid and petrous wings might have closed it. Closure by the latter element is almost complete in Caluromys (Caluromyidae) and some others.

Intervention of the entotympanic bone for complete bullar gap closure in Dromiciops is a unique microbiotheriine trait fully accomplished in the Miocene Microbiotherium sp. (Fig. 7B; see Segall, 1969). The bulla as described above is figured in a skull of Dromiciops by Hershkovitz (1992a, p. 197; 1992b, p. 24, Fig. 10).

4. Presphenoidal sagittal crest of the basicranium (Fig. 8, labeled $s$ )

A sagittally keeled presphenoid of the mesopterygoid fossa is present among living marsupials only in Dromiciops (not seen in others). The midventral crest or keel extends back from the vomer for the length of the basicranium to the basioccipital. The crest is widely distributed among living and extinct eutherians (Hershkovitz 1992a, p. 199). It is figured in therapsids by Romer (1966, pp. 182, 185, labeled ps), and in Dromiciops by Hershkovitz (1992a, p. 200, Pl. IX, labeled $s$ ). 

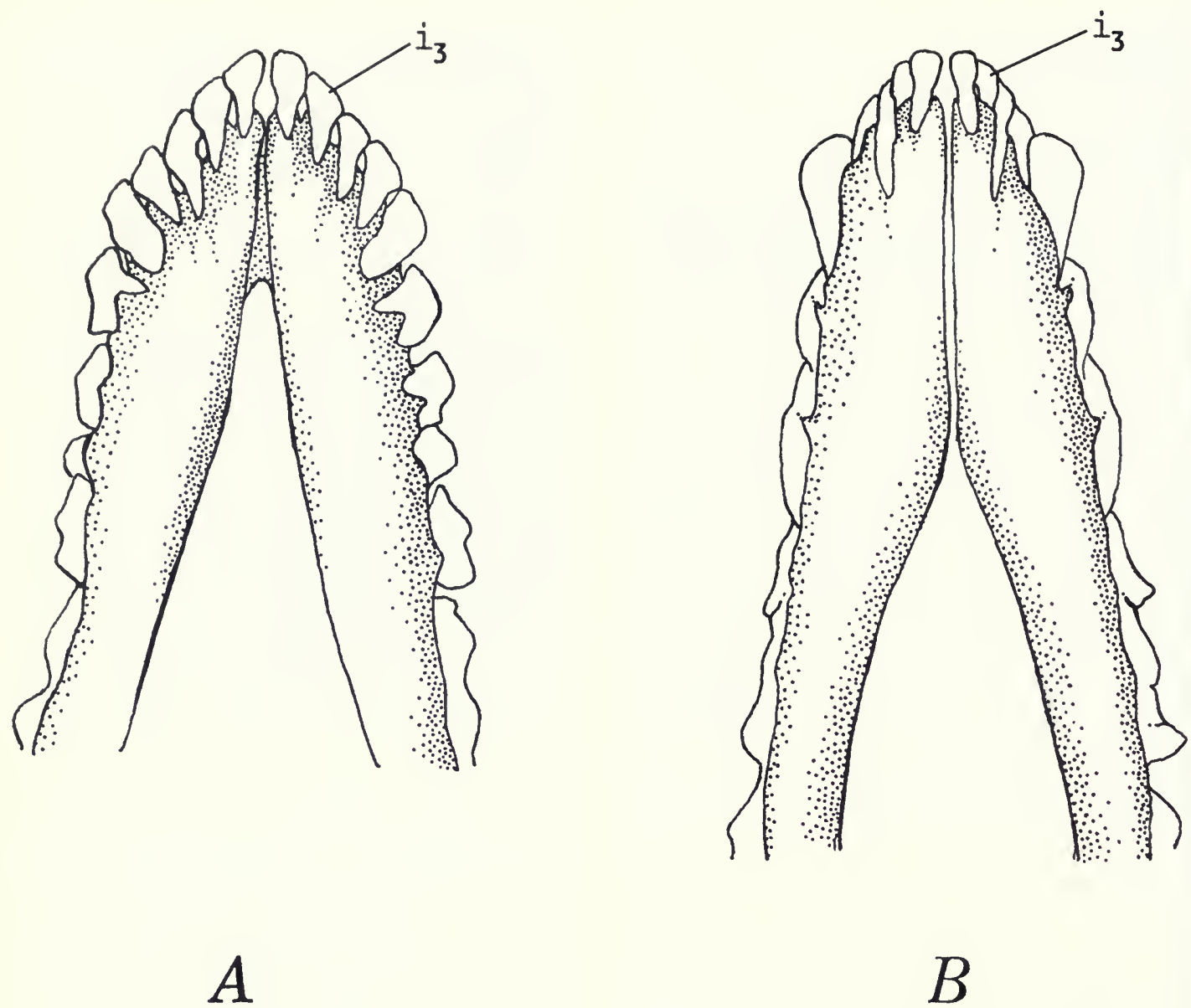

Fig. 5. Ventral aspect of mandibles showing short rounded symphysis (A) of Dromiciops (FMnH 127454), compared with long angular symphysis (B) of a didelphoid (Marmosa, FMNH 69321).

\section{Rete testis (Figs. 9-11)}

The Dromiciops rete testis, according to Woolley (1987), differs from that of all other marsupials in the structure of the rete, greater number of tubules, and encasement in a mediastinum. The character is also mentioned in Hershkovitz (1992a, p. 203).

\section{Cloacas: basicaudal and precaudal (Fig. 12)}

The cloaca in both sexes of Droniciops is basicaudal, a feature shared only with monotremes among mammals, and with reptiles. The derived cloaca is precaudal in all other marsupials except the Didelphidae (as restricted by Hershkovitz, 1997), Macropodidae, and Phalangeridae. In these three families the mouth of the rectal and urogenital ducts of both sexes is completely separated by a perineum that eliminates the cloaca. Exceptions or intergrades occur, however.

It is interesting to note that a precaudal cloaca persists in the eutherians Ochotona (pikas) and many Insectivora, particularly tenrecids.

The evolutionary stages of the cloaca in American and Australian marsupials and in monotremes are outlined by Hershkovitz (1992a, p. 203).

\section{Sexual dimorphism}

Sexual dimorphism with respect to overall size, canine length, coloration, and perhaps other display characters is absent in Dromiciops. In all other marsupials males are consistently larger, the canine tooth usually larger, and the coloration of the venter, particularly the mammary field of females, usually different in the sexes (Hershkovitz, 1997). 


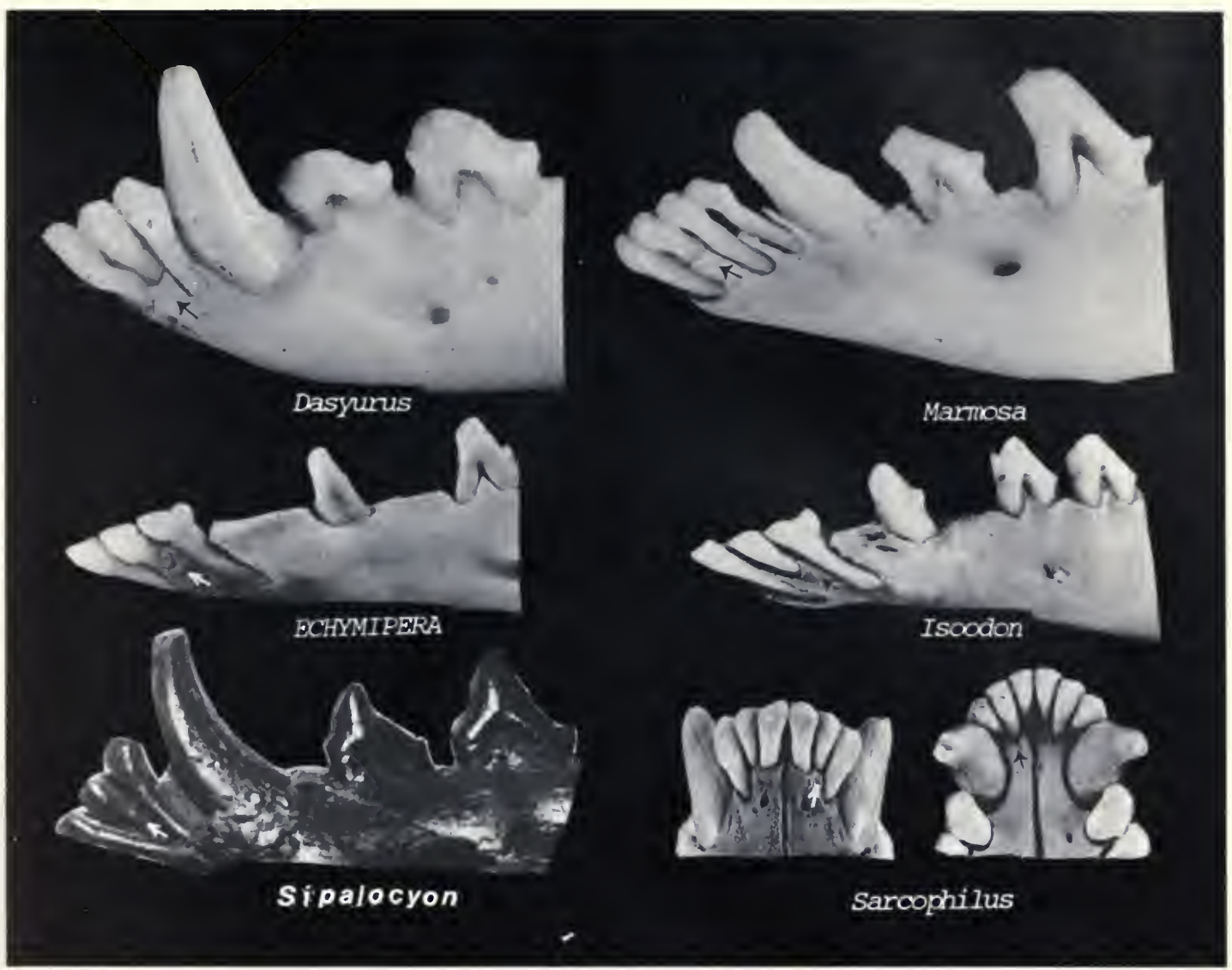

FiG. 6. The staggered or crowded lower third incisor of the Didelphimorphia. From top: Dasyurus (Dasyuridac, Australian); Marmosa (Marmosidae, American); Echymipera (Peramelidae, Australian); Isoodon (Peramelidae, Australian); Sipalocyon (Borhyaenidae, Miocene American); Sarcophilus (Dasyuridae, Australian), dorsal and ventral aspects. Arrows point to staggered lower third (second in line) incisor.

Comment to character 1 above. In two previous publications as well as here, Hershkovitz (1982; 1995) stated that the even spacing of the lower incisors of the Microbiotheriomorphia is the plesiomorphic arrangement and that the staggered third lower incisor of all Didelphimorphia is the derived condition. In a third work (1997), Hershkovitz referred the metatherian Pucadelphys andimus Marshall and de Muizon to the Microbiotheriidae on the basis of its nonstaggered lower incisors. In a disturbing perversion of the facts, Marshall et al. (1995, p. 68) declared that "Given the nearly universal occurrence of this staggered i3 in metatherians, Hershkovitz concluded that this state [the staggered $i_{3}$ ] was plesiomorphic[!] for this group [Metatheria]." Marshall et al. (1995, p. 68) did at least arrive at my real assess- ment, without acknowledgment of source, to wit, that "the staggered i3 is here regarded as a derived state which appears to be synapomorphic for methatherians except Pucadelphys and Microbiotheriidae." Notwithstanding, and contrary to their conclusions, Marshall et al. (1995. p. 17) erroneously referred Pucadelphys to the family Didelphidae. Their explanation (Marshall et al., 1995, p. 84): "because its molar structure (which is currently the foundation of metatherian systematics) is indistinguishable from that family. We thus give preference to molar structure in classifying Pucadelphys within Metatheria." The molars are indeed metatherian characters but the phylogenetically most significant dental features of marsupials are in the antemolar fields, most notably the lower incisive. 

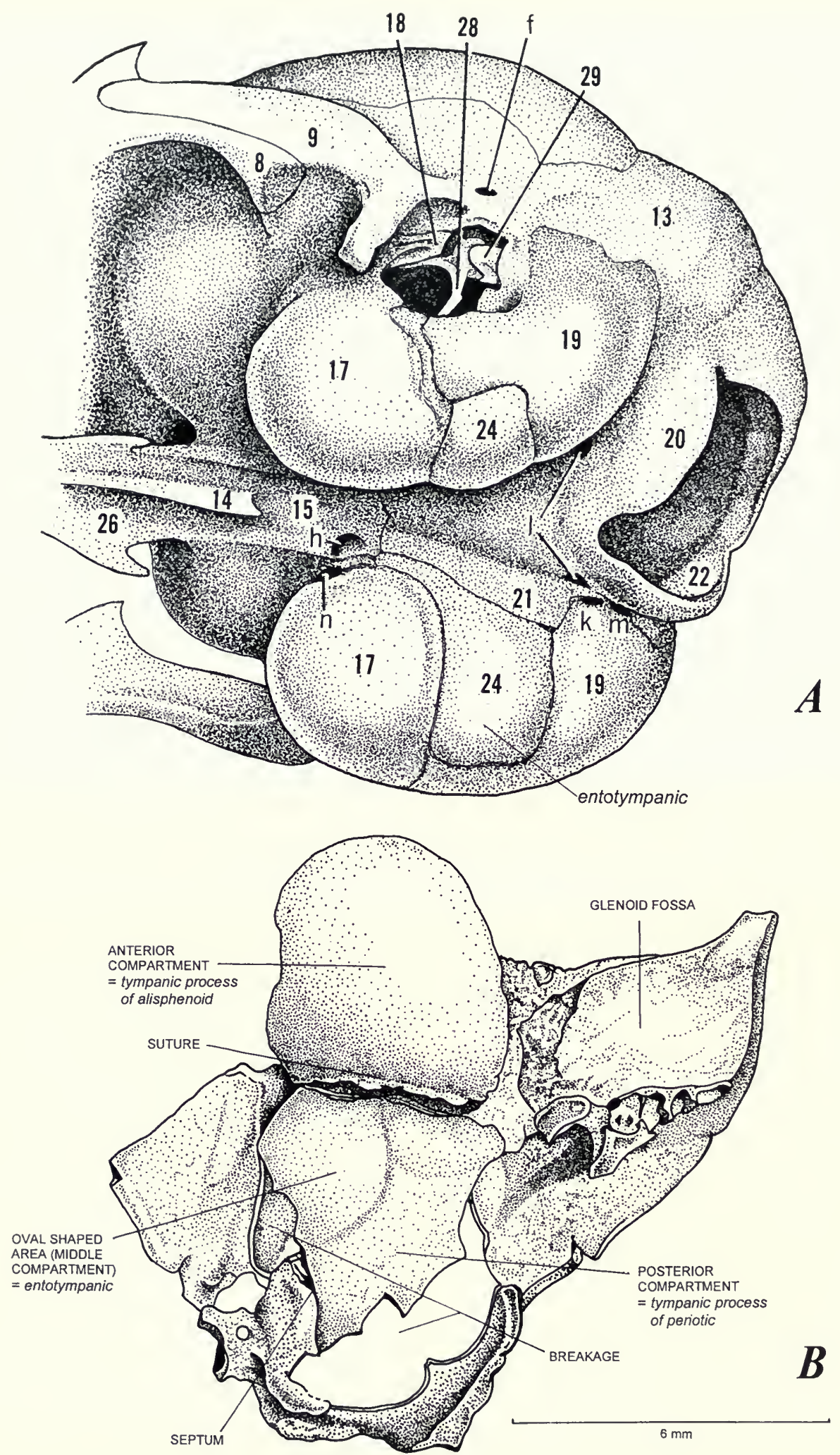


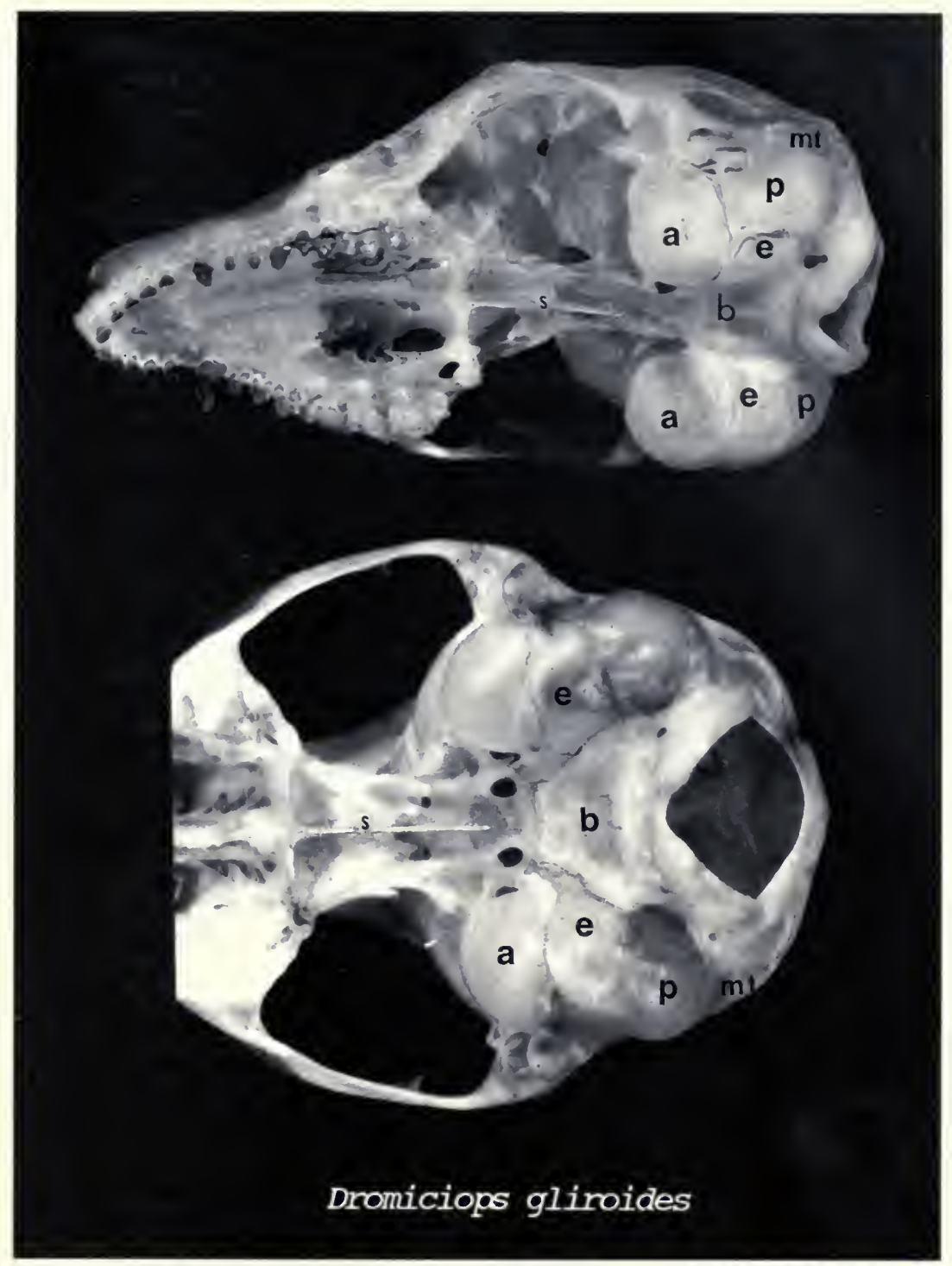

FIG. 8. Dromiciops gliroides. Two views of basicranium showing basisagittal crest (s): Bones are a. alisphenoid: b, basioccipital: e. "entotympanic": p, petrous; mt, mastoid; s, basisagittal crest of presphenoid. Figure from Hershkovitz (1992a).

FIG. 7. A, Auditory bullar portion of Dromiciops skull; bone 24 is the so-called "entotympanic." which in microbiotheriids fills the gap between the alisphenoid tympanic process (17) and the petrous tympanic process (19). For names of other cranial elements, see key (p. 39). B, Crushed, disassociated auditory bulla of Microbiotherium sp. (Miocene, Patagonia) was probably indistinguishable in undamaged state from a Recent Dromiciops gliroides bulla. Figure copied from Segall (1969) with original labels capitalized; italicized labels added. 

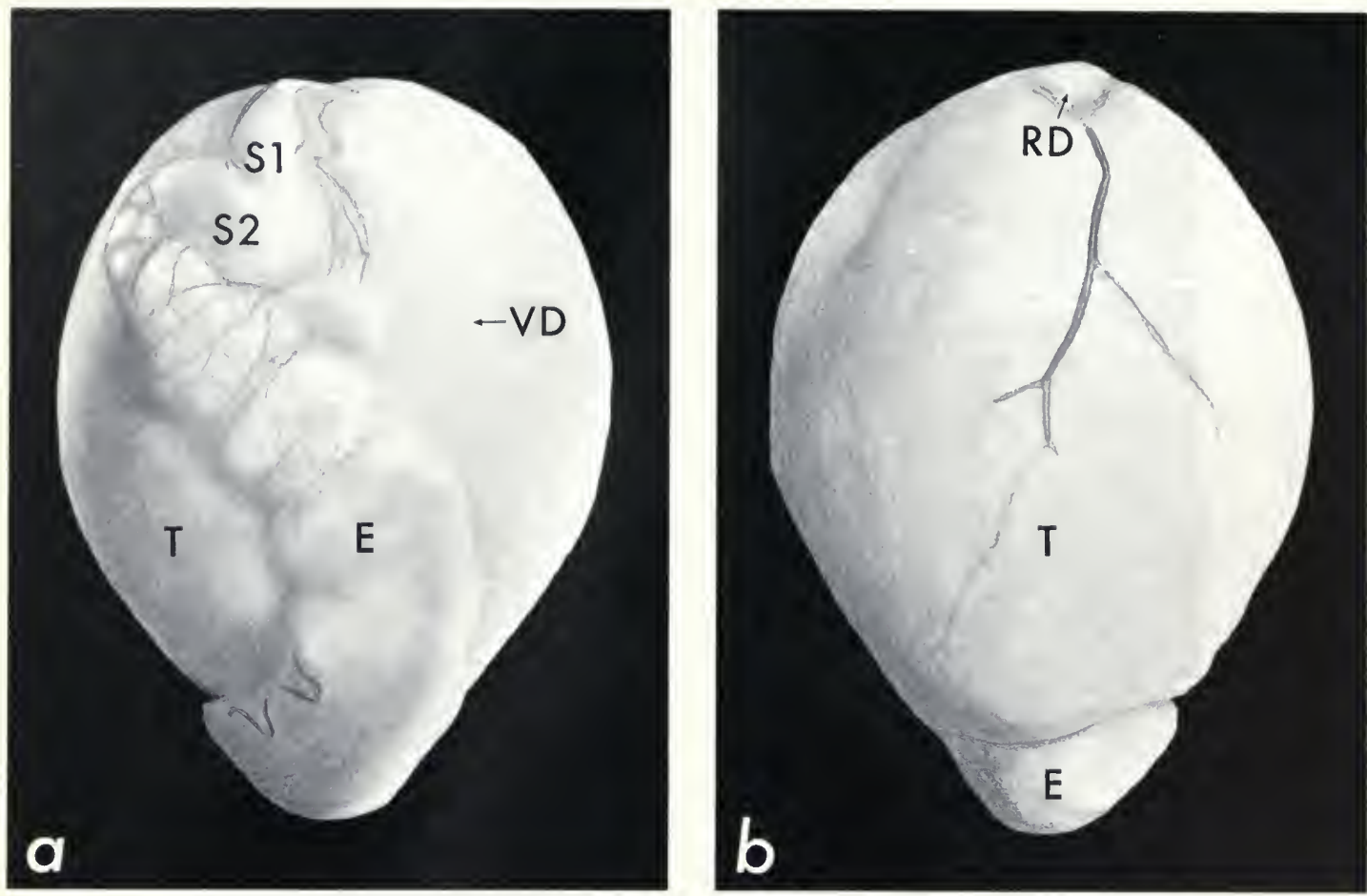

FIG. 9. Testis, efferent duct system, and epididymis of Dromiciops gliroides: (a) dorsal aspect and (b) ventral aspect. $\mathrm{T}=$ testis; $\mathrm{E}=$ epididymis; $\mathrm{S} 1$ = first segment of efferent duct system; $\mathrm{S} 2=$ second segment of efferent duct system; RD = extratesticular rete duct; VD = vas deferens. Figures copied from Woolley (1987, p. 219); reproduced courtesy of Surrey Beatty \& Sons Pty. Ltd.

\section{Subsidiary Characters}

1. Ectotympanic bone fully enclosed within an inflated auditory bulla. Character state is derived (Fig. 7). In the didelphoids Caluromys and Caluromysiops (Caluromyidae) and in Glironia (Glironiidae) the same bone is nearly to entirely enclosed, but the bulla is not inflated. "There is no evidence of an ossified ectotympanic [in Pucadelphys] . . nor are there facets in the ear region which marked the site of attachment of this bone" (Marshall et al., 1995, p. 64).

2. Ears are relatively small, tapered, hairy in correlation with the cool habitat (Fig. 13).

3. Small, nearly incisiform lower canines in Dromiciops contrast with the large canines of other marsupials except diprotodonts (Figs. 5, 6 ) and could be but need not be correlated with absence of incisor crowding in microbiotheriids. The Dromiciops small canine may be nearer primitive proportions, rather than secondarily reduced. Upper and lower canines of Pucadelphys are large.

4. Pouch with 4 nipples, 2 on each side, none centered (Fig. 14). The same pattern occurs in the caenolestids Caenolestes and Lestoros (Kirsch \& Waller, 1979), but not in Rhyncholestes, with 7 (3-1-3) (Patterson \& Gallardo, 1987). Nipples in Australasian marsupials range from 2 to 12 , the number even in each species (Collins, 1973).

\section{Incidental Contments}

1. Tarsal bones in marsupial phylogeny: A biological fallacy (Fig. 15)

As cited from Hershkovitz (1992a, p. 181, abstract): The "arrangement of the Marsupialia [by 

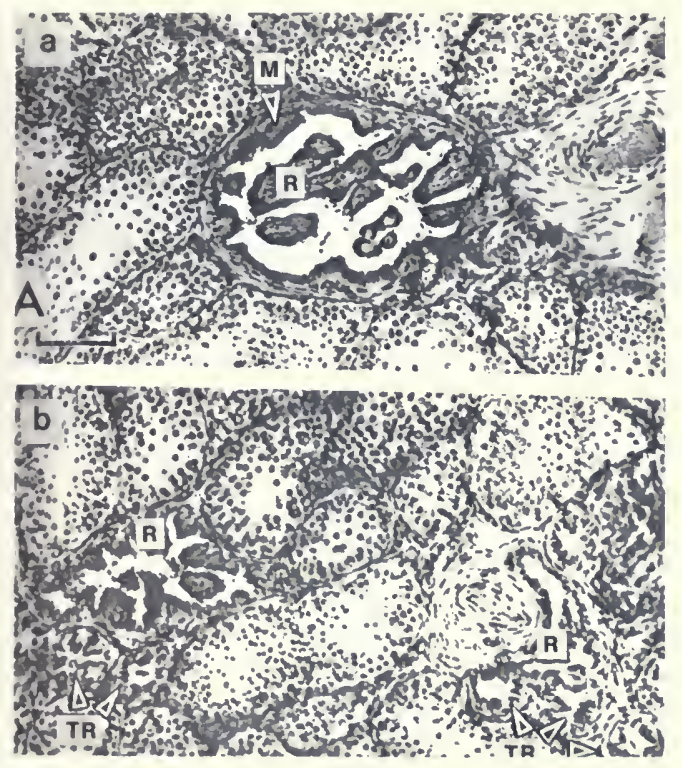
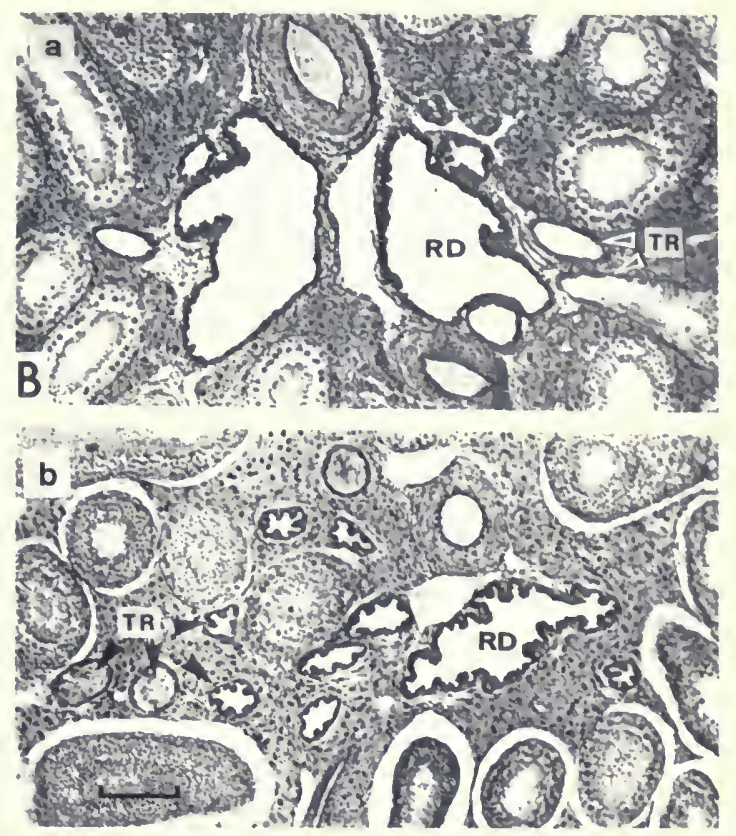

Fig. 10. Dromiciops gliroides: A, Left top and bottom, section through (a) main channels and (b) the two branches of the rete. (Level of sections shown in Fig. 11.) $\mathrm{R}=$ rete; $\mathrm{M}=$ mediastinum; $\mathrm{TR}=$ tubuli recti. Scale line $=0.1$ mm. B, Right top and bottom, section through the rete and tubuli recti of (a) Didelphis albiventris and (b) Philander opossum. RD = rete duct; $\mathrm{TR}=$ tubuli recti. Scale line (in right lower quadrant) $=0.2 \mathrm{~mm}$. Copied from Woolley (1987, pp. 223, 224). Reproduced courtesy of Surrey Beatty \& Sons Pty. Lid.

Szalay, 1982b] into cohort Ameridelphia encompassing all New World marsupials except Microbiotheriidae, and cohort Australidelphia containing all Australian [marsupials] and the American Microbiotheriidae, based primarily on the pattern of articulation between the foot bones astragalus and calcaneus, has no leg to stand on." It is shown (Hershkovitz, 1992a) that the joint patterns are variable and intergrading and that the "continuous" pattern said to be exclusively Australidelphian evolved independently more than once from the "separate" joint pattern said to be an exclusive feature of Ameridelphia. The two patterns occur in both hemispheres. The morphology of astragalus and calcaneus of the metatherian Dromiciops, treated by Szalay as the australidelphian "morphotype," varies between the two patterns but is essentially ameridelphian or didelphoid, and little if at all different from the ankle bones of some didelphoid mouse opossums (cf. Gracilinanus marica [Hershkovitz, 1992b, Pl. [II]).

Woodburne and Case (1996, p. 142) acknowledge the variability of the morphology and disperal of both types of ankle bones on the two continents. Surprisingly, the confession is followed by a non sequitur (p. 143), which declares that 'Hershkovitz' (1982, 1992[a], 1995) proposals seem unsupportable in the face of a large number of character conflicts." They fail to mention a conflict but conclude, despite their awareness of the inconsistencies (p. 142), that "ankle joint morphology remains the best character supporting monophyly of the Australidelphia"; the statement is iterated on page 155 .

Tarsal bones are mammalian features, and neither of the two derived patterns is restricted to either ameridelphian or australidelphian. The geographic terms are, nevertheless, useful in a vernacular sense.

\section{Ankle bones}

Woodburne and Case object to my failure (Hershkovitz, 1992a) to "address the other ankle joint morphologies utilized by Szalay (1982a, b).," To this may be added Szalay's (1994) treatise, which is replete with descriptions of ankle bones, many of them fragmentary, none diagnostic. Careful study of the data reveals that ankle bone 

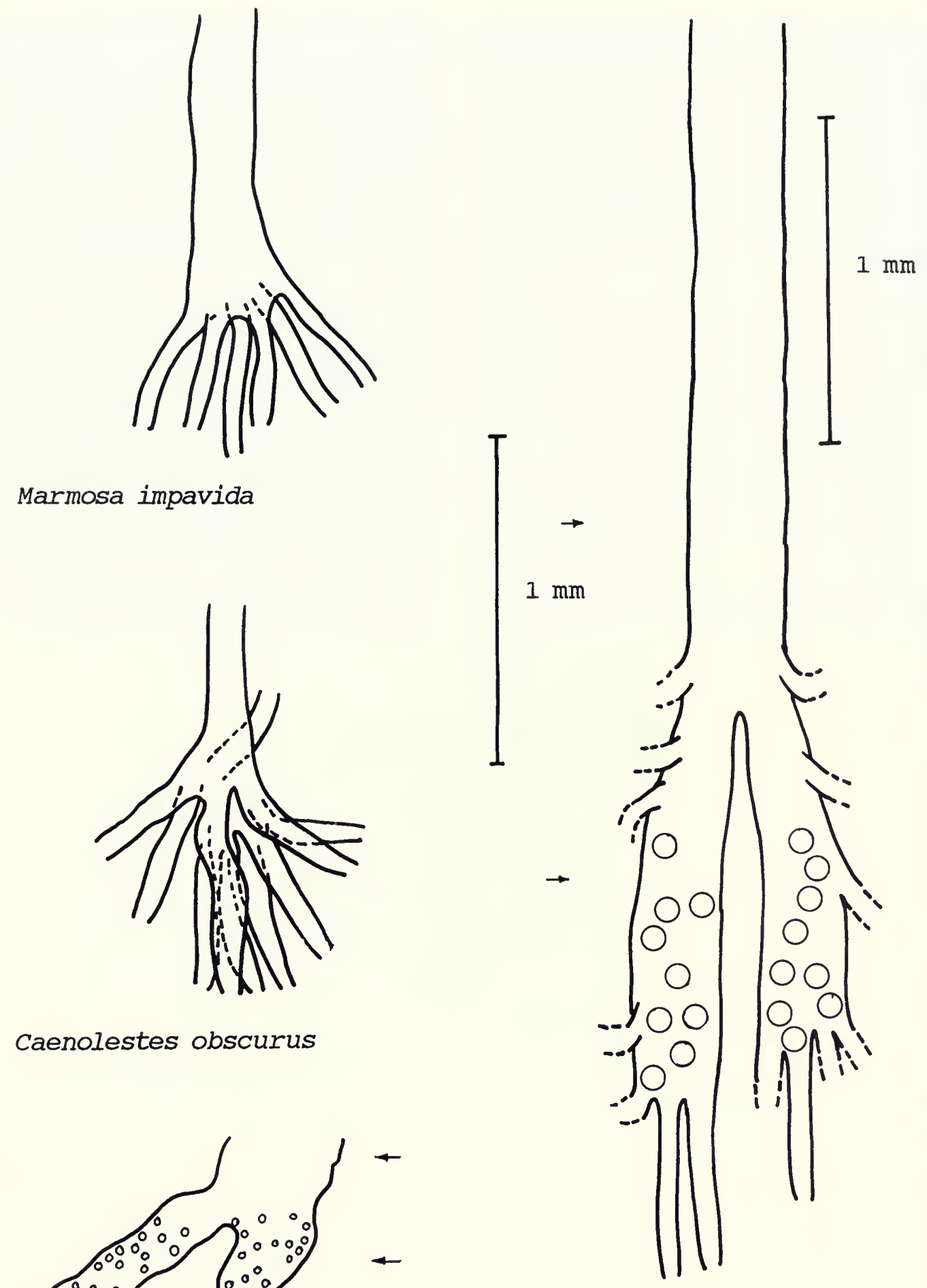

Caenolestes obscurus

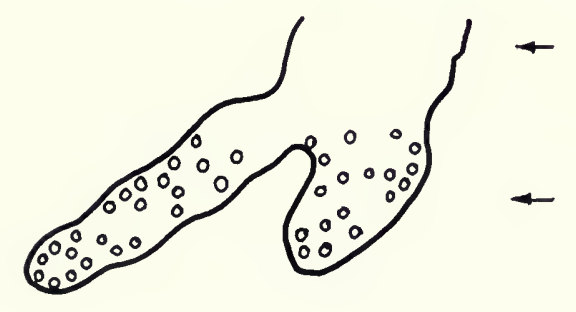

Didelphis albiventris

Dromiciops gliroides 


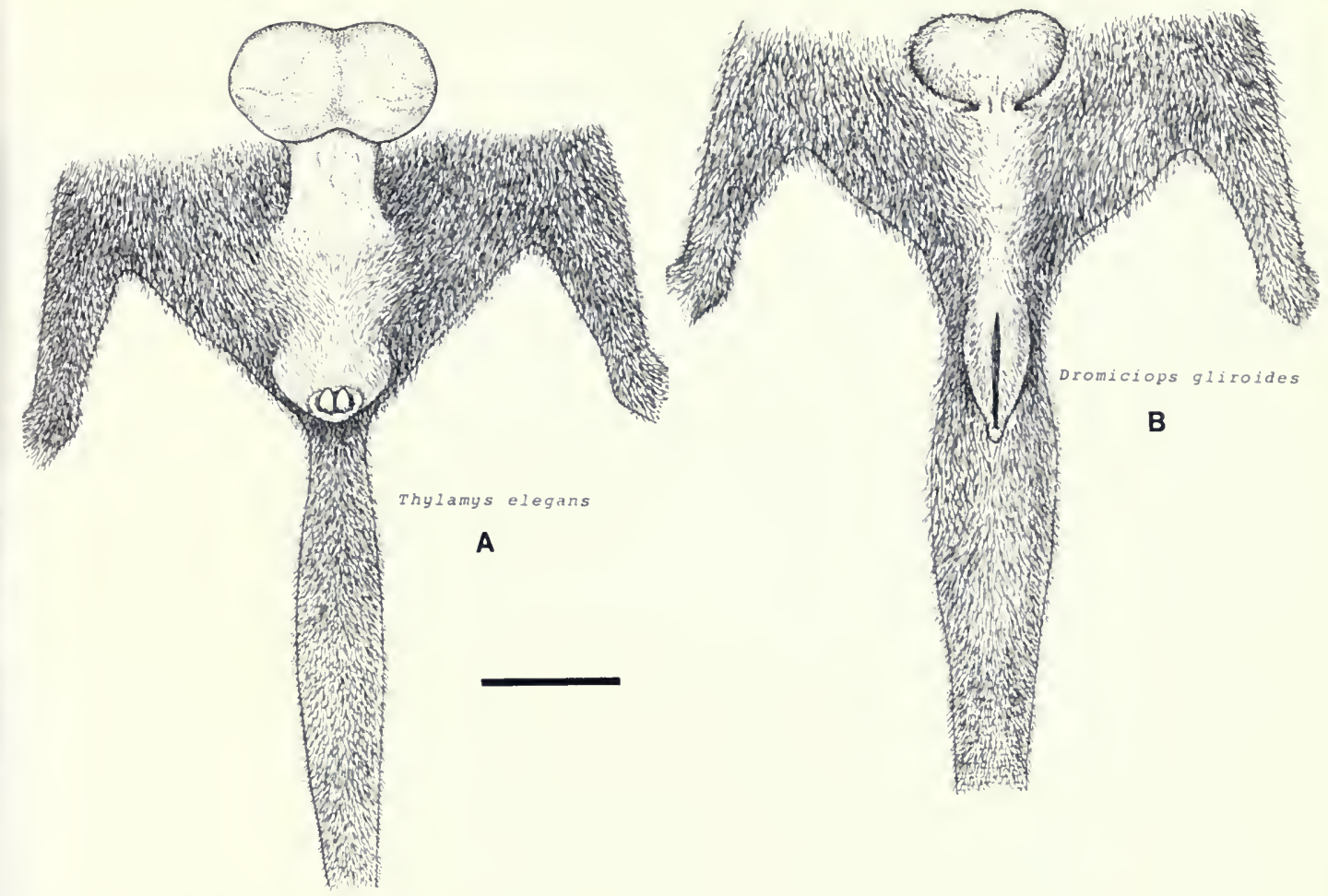

FIG. 12. A, Cloaca precaudal in Thylamys, bifurcated glans penis showing at opening, scrotum pendulous. B, Cloaca basicaudal in Dromiciops, scrotum sessile. Bar $=1 \mathrm{~mm}$.

patterns with their consistencies and inconsistencies as tabulated by Hershkovitz (1992a, p. 186) provide more than adequate justification for rejection of Szalay's hypothesis of phylogenesis based on them.

\section{Molars (Fig. 16)}

The incomplete quotation from Woodburne and Case (1996, p. 143) says that Hershkovitz (1992a, p. 208) holds that “" 'retention' in Dromiciops of a narrow buccal shelf in the upper molars, while virtually 'lacking' a stylar cusp $B$, would place Dromiciops outside of all Marsupialia under current definitions."

Actually, Hershkovitz (1992a, p. 208) said "Dromiciops molars retain the early mammalian high cusped tritubercular euthemorphic crown pattern with buccal shelf narrow, stylocone (cusp $B$ or $j$ of authors) diminutive or hardly more than suggested. Although primitive in design no feature of the Dromiciops molars is peculiar to the genus. Molars of caenolestids and the didelphoid Caluromysiops are also euthemorphic but more molarized. Molar crown patterns of all other marsupials including Caluromys are dilambdomorphic with the W-shaped eocrista [or centrocrista] secondarily derived from the euthemorphic pattern (cf. Hershkovitz, 1977, p. 279)." The buccal shelf is usually variably developed, the stylocone (cusp B) often poorly developed or absent.

The "current definition" of Marsupialia mentioned by Woodburne and Case appears defective in light of the variability of width of stylar shelf and degree of development of stylar cusp B in microbiotheriids and marsupials generally (cf. Hershkovitz, 1972, Fig. 19). My description of Dromiciops dentition agrees with that of Reig (1955), who was the first to recognize its microbiotheriid characters.

FIG. 11. Diagrams of testicular rete of Marmosa, Caenolestes, Dromiciops, and Didelphis; redrawn from Woolley (1987. p. 220); reproduced courtesy of Surrey Beatty \& Sons Pty. Ltd. 

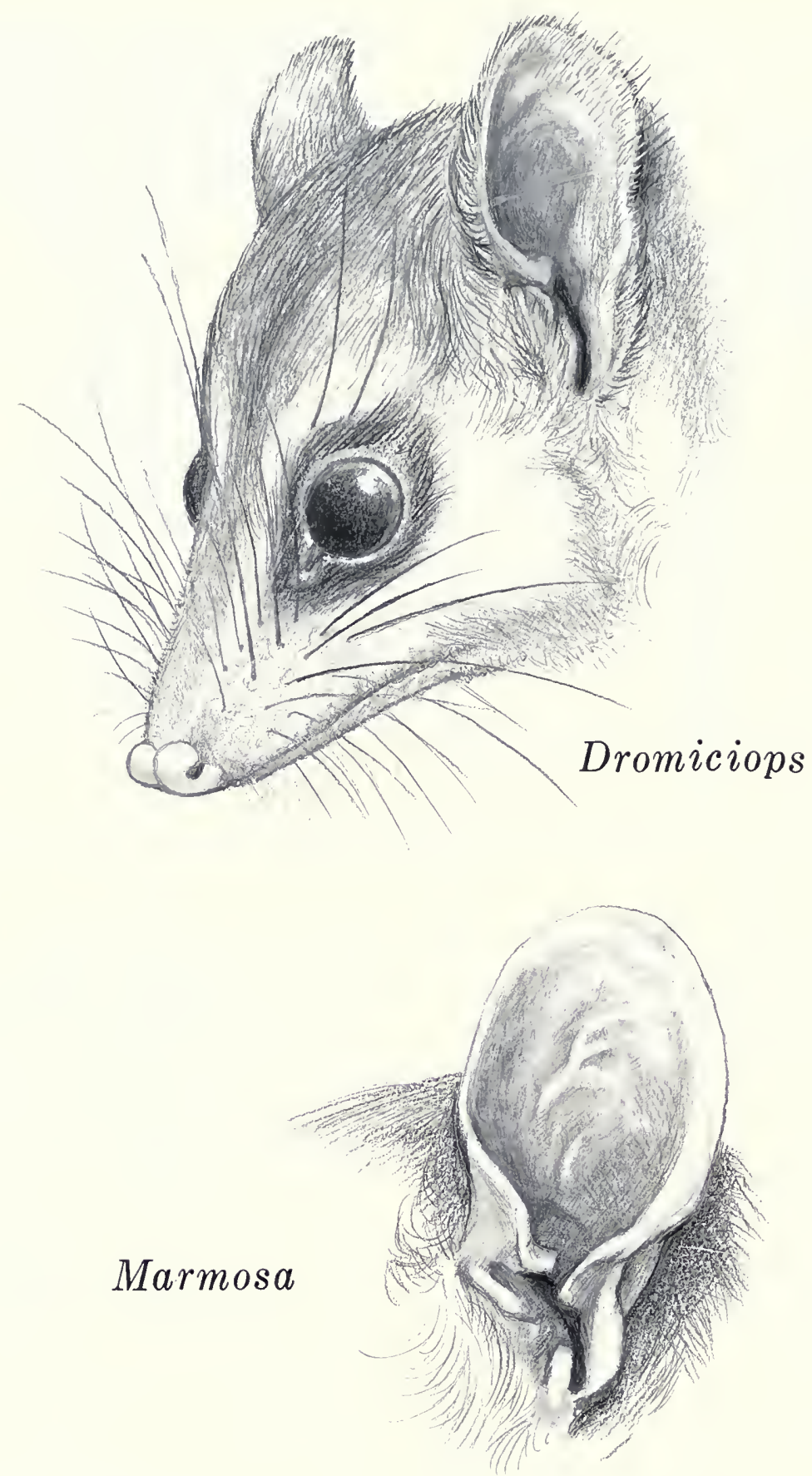

FIG. 13. Hirsute ear of Dromiciops gliroides contrasted with comparatively naked ear of a mouse opossun (Marmosa). 


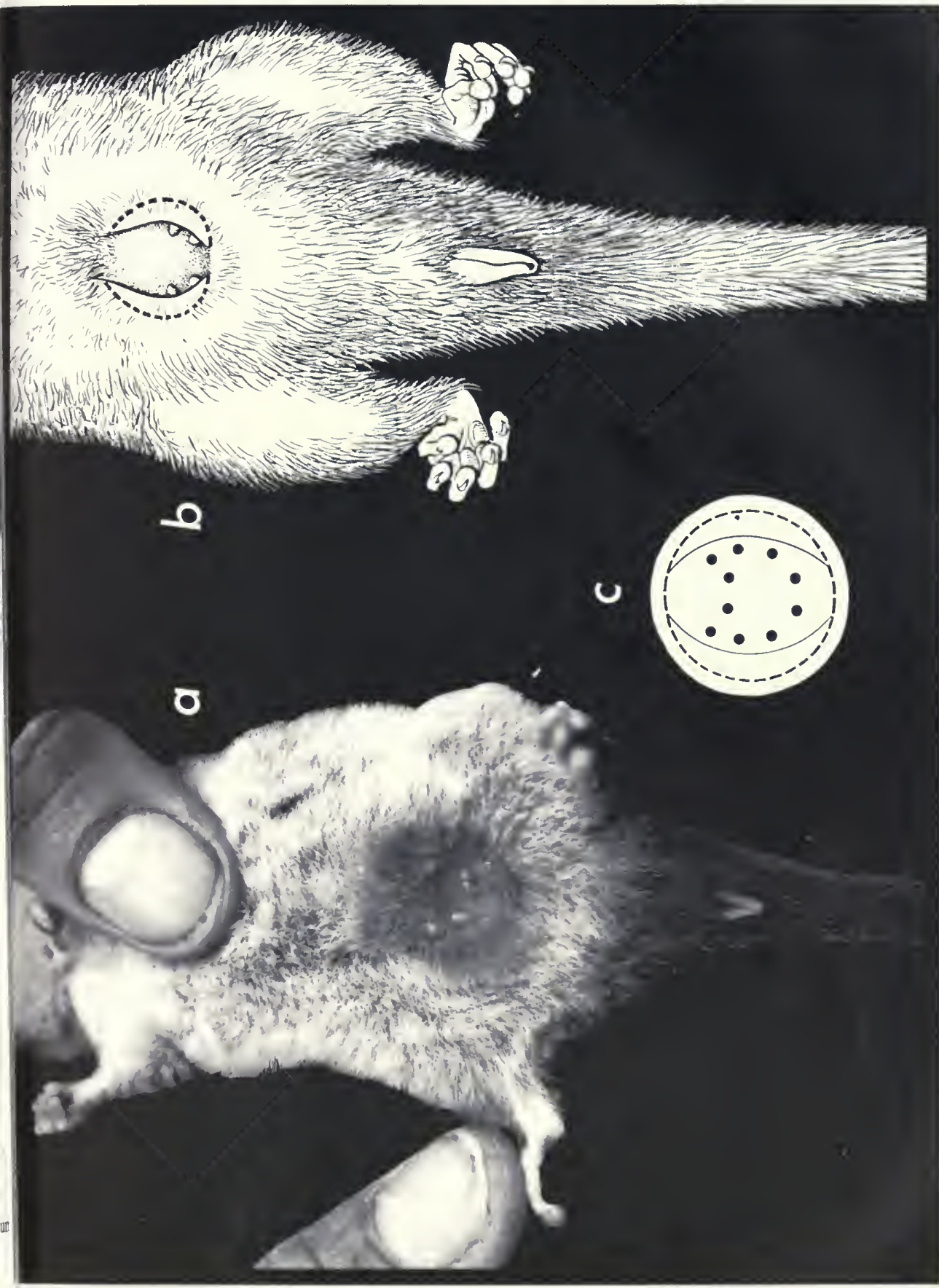

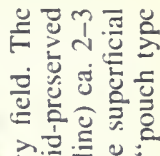

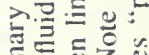

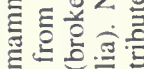

o造诃

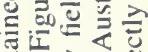

- $=$ 등

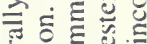

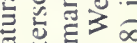

武 5

可记

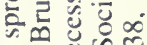

중츨

원

可焉次

5.5

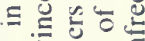

马ं

웅은 등

诸

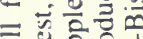

ने

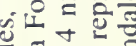

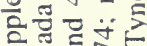

․․을

드늘

음

응. 드그을

可产运

I을 톤

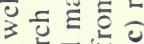

$\checkmark$ 呐

든

3508

可恙: 旨

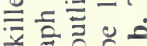

入

을도

논

ㄴ.

政政

응

6. 궁

等过

능워

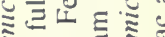

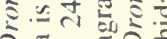

(3)

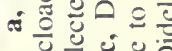

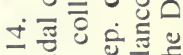

找

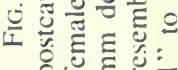




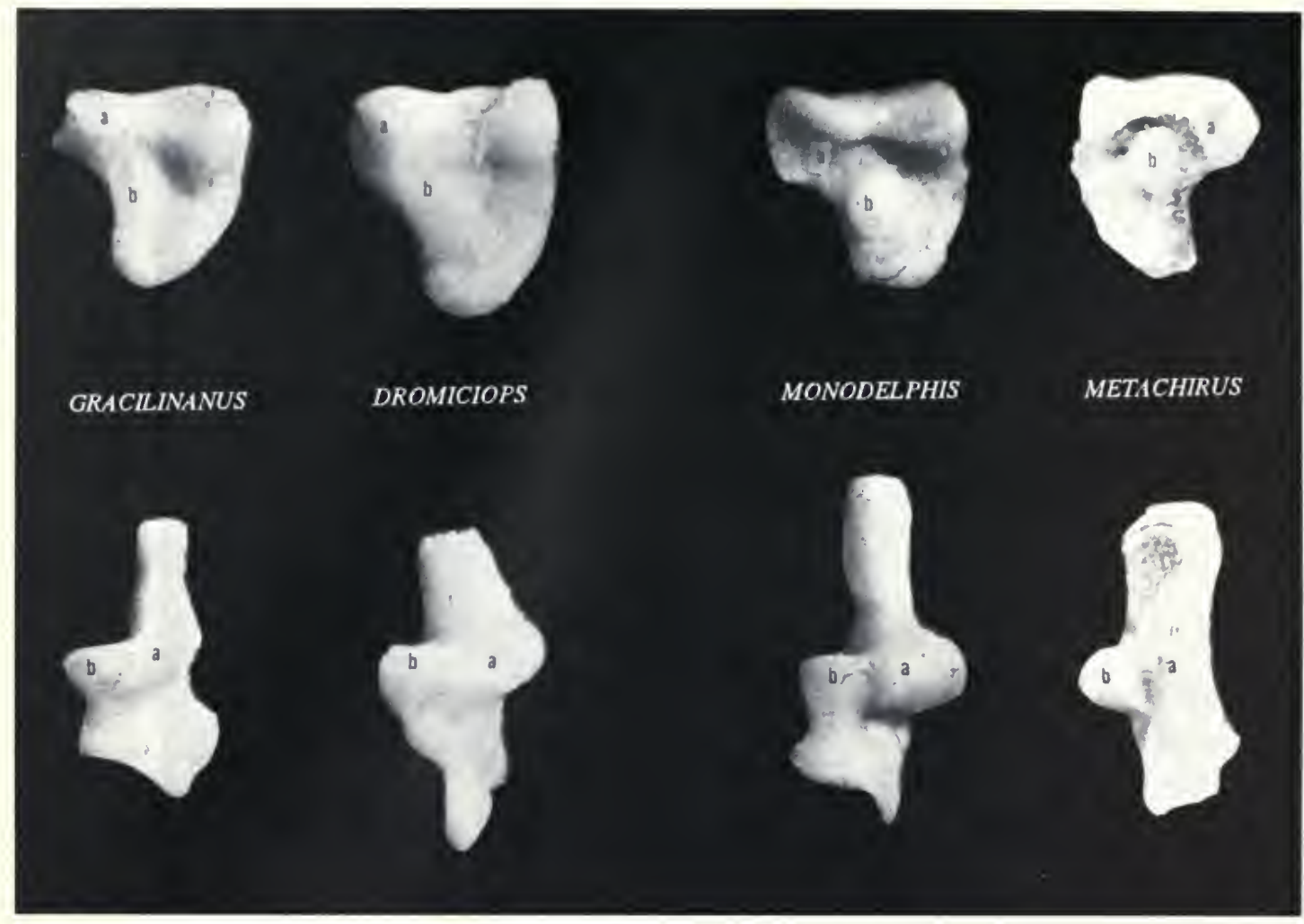

FIG. 15. Tarsal bones of four American marsupials: Upper row astragali, lower row calcanei of same individuals, $\mathrm{L}=$ left, $\mathrm{R}=$ right; not to scale. From left to right: Gracilinanus marica (FMNH 18907L); Dromiciops gliroides (FMNH 50072); Monodelphis palliolatus (FMNH 22178L); Metachirus nudicaudatus (FMNH 70988, astragalus R, calcaneus L). Joint patterns (a, b) of first and second paired astragali and calcanei are "continuous." Joint patterns (a, b) of third and fourth paired astragali and calcanei are "separate."

As defined by its reproductive system, Dromiciops is a marsupial.

\section{Oldest marsupial (Fig. 17)}

According to Woodburne and Case (1996, p. 147), "The paleontological data are in agreement with the rDNA studies suggesting that didelphids [actually didelphoids] diverged from other marsupials [which?] about 62 m.y. ago. ... Springer et al. (1996) suggest that didelphids diverged from other marsupial orders [which?] about $75 \mathrm{Ma}$, but there currently are no fossil didelphids that old."

The Albian (Early Cretaceous) didelphoid Adinodon Hershkovitz (1995), ignored by Woodburne and Case (1996), and Kokopellia Cifelli of the same age lived more than $100 \mathrm{Ma}$ and must have diverged from an older Early Cretaceous didelphoid (?), possibly even a Late Jurassic one.
5. Staggered first-generation $i_{3}$ is plesiomorphic

"Hershkovitz (1995) proclaims that didelphoids are (a) much older than commonly considered as based on other features, such as a Vshaped centrocrista (upon which he does not comment), but also that the members of this group are plesiomorphic in having this trait (p. 160, No. 5)" (Woodburne \& Case, 1996, p. 142).

The cited work of Hershkovitz (1995) is concerned with the staggered $i_{3}$. Molars are not mentioned therein, and comment on the centrocrista would be out of place. Where Woodburne and Case got the above-quoted interpretation is nol found in any of my published works. What is saic on cited page 160 , No. 5, under Metatheria is "Staggered condition of first generation $\mathrm{i}_{3}$ (or alveolus) is plesiomorphic for all didelphoids including the Australian forms." 

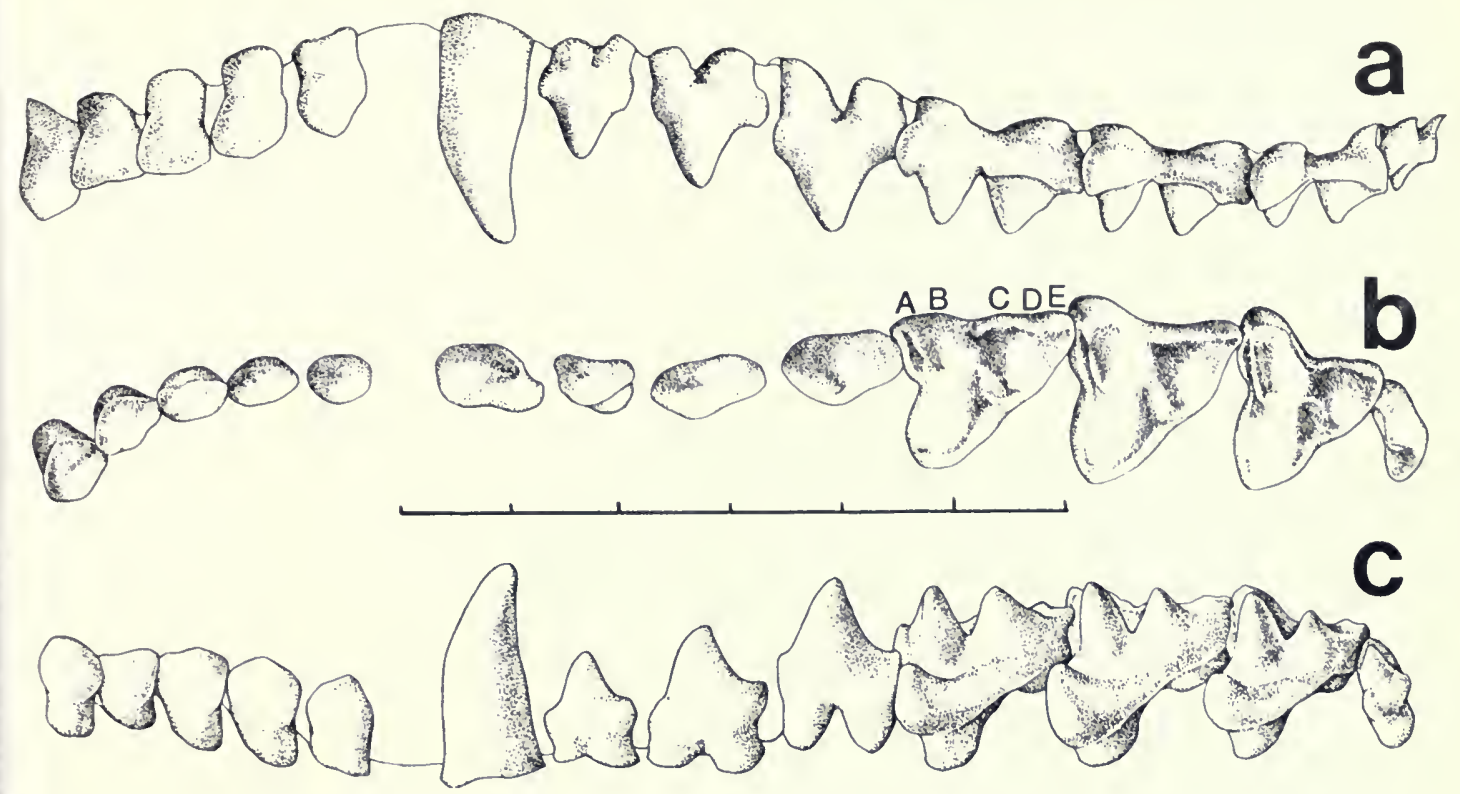

Fig. 16. Upper dental system of Dromiciops gliroides, from Marshall (1982, fig. 16); a, labial; b, occlusal; c, lingual. Bar $=6 \mathrm{~mm}$. Stylar cusps of $\mathrm{m}^{1}$ labeled.

6. Caecum, declared loss (Fig. 18)

Aplin and Archer (1987, p. xxxvii) state that Dromiciops shares with all members of the Dasyuromorphia and Notoryctemorphia, and with Tarsipes (alone within the Order Diprotodontia), the derived loss of an intestinal caecum. Hume (1982) is cited as source.

According to Hume (1982), Australian members of the families noted by Aplin and Archer lack a caecum, but nowhere in his text is Dromiciops mentioned. This taxon, like all other American marsupials described or figured by Hume (Marmosa [sensu lato], Philander, Chironectes, Didelphis, Caenolestes), has an intestinal caecum. That of Dromiciops (FMNH 129815) is present and figured.

\section{Seeming similarities}

Some seeming dental and cranial similarities between microbiotheres and Recent Glironia, Caluromys, and Caluromysiops prompted Reig (1955) to assign those genera to the Microbiotheriinae, perceived by him as a subfamily of Didelphidae.

\section{Epitome}

The five most important events in the history of marsupial classification are the following.

1. Determination of the South American Dromiciops as a genus of microbiotheriid (Reig, 1955).

2. Systematic separation of microbiotheriids with 4 evenly spaced lower incisors from all other marsupials or didelphimorphs, all with derived staggered lower third incisors (Hershkovitz, 1982, 1995).

3. Discovery of Adinodon (Didelphoidea), oldest known marsupial with staggered $i_{3}$, recovered from the Albian (Lower Cretaceous) of Texas (Patterson, 1951; Hershkovitz, 1982, 1995).

The possibility that Holoclemensia Slaughter (1968b) is the same as or nearly related to Adinodon has been suggested by Turnbull (1995), but its lower incisors are unknown.

4. Persistence of the derived character of a staggered $\mathrm{i}_{3}$ suggests a Late Jurassic origin of didelphimorphs and an earlier origin of the phylogenetically antecedent microbio- 


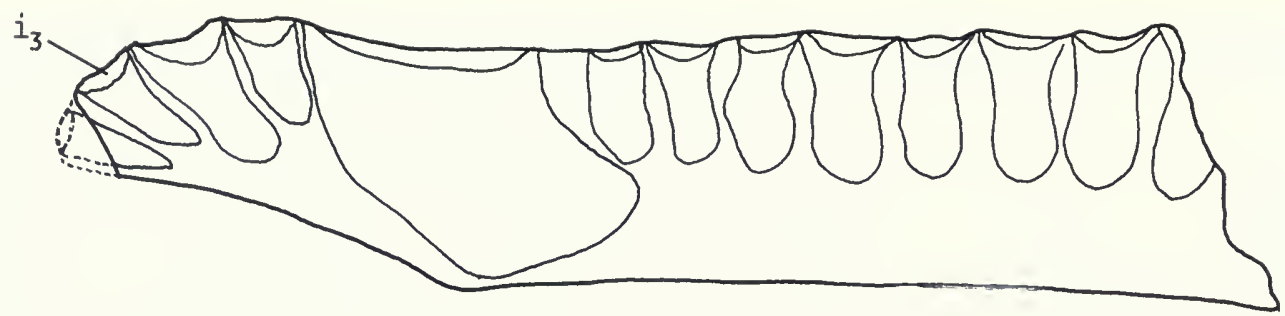

$1 \mathrm{rmm}$

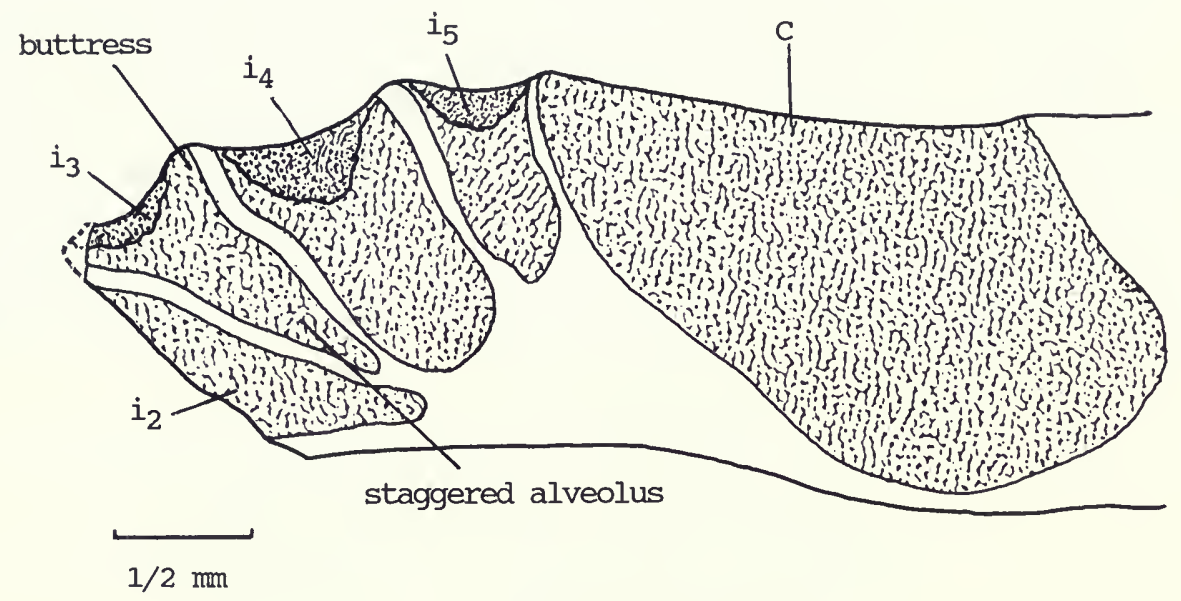

ADINODON PATTERSONI

FIG. 17. Adinodon pattersoni (holotype); fragment of left ramus cleared with oil of anise for revealing alveolar outlines. Top, buccal surface of fragment $\mathrm{i}_{2-5}, \mathrm{c}, \mathrm{p}_{1-3}, \mathrm{~m}_{1}$, redrawn from Patterson (1956): bottom, same specimen with $i_{2-5}, c$ only, seen from labial surface tilted slightly inward to reveal full depth of staggered alveolus of $i_{3}$. Copied from Hershkovitz $(1982,1995)$.

theriids now known from the Early Paleocene of Bolivia.

5. Marsupialia (Metatheria) evolved independently of Eutheria, and each arose from a different stem of the Therapsida.

\section{Dromiciops gliroides Thomas}

SYNONYMY

Didelphys elegans Cunningham (not Thylamys elegans Waterhouse, a marmosid), 1871: 362.

Didelphys australis F. Philippi, 1893a:318-
CHILE: Valdivia (near Unión, type locality $40^{\circ} 17^{\prime} \mathrm{S}, 73^{\circ} 05^{\prime} \mathrm{W}$ ); holotype a mounted skin, skull inside, Museo Nacional, Santiago de Chile; name preoccupied by Didelphys australis Goldfuss (1809:219) (Pennants New Holland opossum, a phalangerid). F. Philippi, 1893b:33, pl. (animal)CHILE: Valdivia (near Unión). R. A. Philippi, 1894:33, pl. 4, fig. 2 (animal)CHILE: Valdivia; Llanquihue; Araucania. Wolffsohn and Porter, 1908:69-CHILE: Curacautín; local names: monito del monte, klimiuma, wenukiki, kongoi-kongoi; gliroides Thomas, a synonym. 


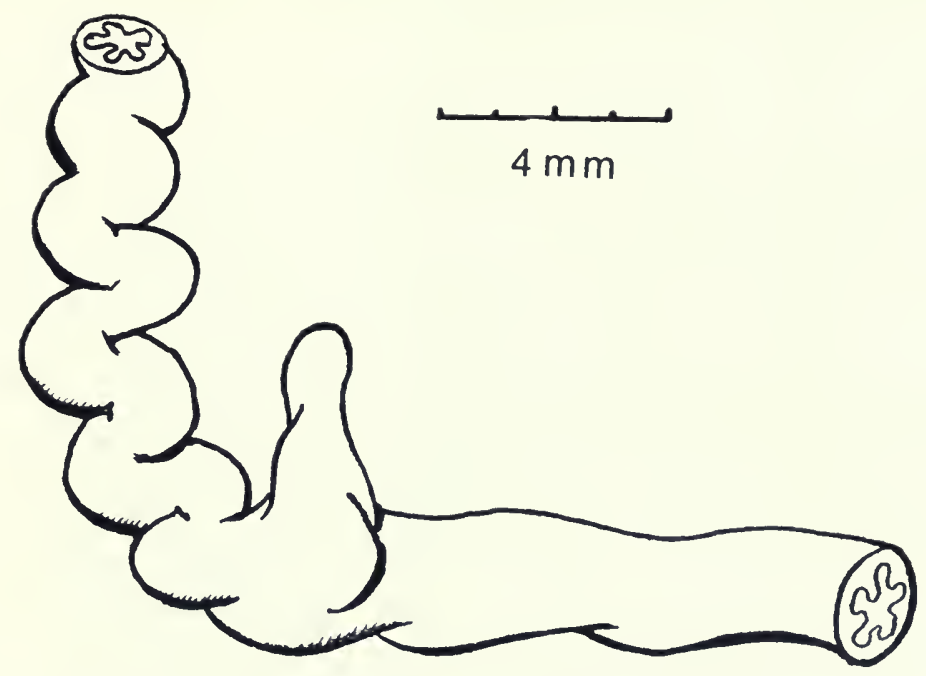

FIG. 18. Caecum of Dromiciops gliroides (FMNH 129815). Alleged to be absent in microbiolheriids by Aplin and Archer (1987).

Dromiciops australis Thomas, 1919:212-ARGENTINA: Neuquén (Beatriz, Nahuel Huapí, 800 m); CHILE: Cautín (Temuco). Cabrera, 1919:30, pl. 1, fig. 1 (head). Krieg, 1925:173, fig. 2 (head, tail), fig. 3 (pouch), characters, comparisons. (Reig, 1955, p. 127)-Dromiciops a microbiotheriid. Mann, 1955:159, figs. 1, 2, 4, 7 (tail, hand, foot, marsupium), figs. 3, 5 (skull), fig. 6 (liver), fig. 8 (female reproductive tract)-CHILE: Valdivia (between Valdivia and Puerto Montt); characters, habits, thermoregulation. Mann, 1958:209, figs. 1, 2 ( $q$ genitalia), fig. 3 (marsupium), fig. 4 (teats), fig. 5 (newborn), fig. 6 (juvenile), fig. 7 (nest)—reproductive organs, habits of newborn. Lyne, 1959:84-distribution of vibrissae. Segall, 1969:489, figs. 1-4 (skull; middle ear, auditory ossicles)-middle ear region, comparisons, classification (Microbiotheriinae). Reig et al., 1972:39karyotype, $2 \mathrm{n}=14$. Reig et al., 1977:199, 202-karyotype, $2 \mathrm{n}=14$. Marshall, 1978: 1, fig. 1 (skull), figs. 2, 3 (dentition), fig. 4 (map distribution); characters, habits. Marshall, 1982:35, fig. 12 (map distribution), fig. 13 (skull), figs. 14-19 (dentition), fig. 21 (size relationships); characters, comparisons. Pearson and Pearson, 1982:129ARGENTINA: Río Negro (Parque Nacional Nahuel Huapí); habitat, rodent censuses in three Nothofagus-Chusquea forests.
Meserve et al., 1988:721-CHILE: Osorno (La Picada); diet. Patterson et al., 1989: 67-CHILE: Osorno (La Picada); distribution, abundance, capture (snap trap positive, live trap negative). Patterson et al., 1990:620 —CHILE: Osorno (La Picada); distribution, habitat.

Dromiciops australis australis, Osgood, 1943: 48, fig. 2 (skull) - characters; distribution; CHILE: Llanquihue (Cayetué, Lago Todos Santos; Peulla, Lago Todos Santos); Concepción (Lota, southwest of Concepción); Malleco (Río Colorado; Victoria; Sierra Nahuelbuta). Santos, 1946:191, pl. I (rhinarium, foot, hand, tail), pl. 2 (animals)ARGENTINA: Neuquén (Huemul, Nahuel Huapí; Villa Angostura, Nahuel Huapí); characters; habits; local names, llaca, monito del monte. Greer, 1965:103-CHILE: Malleco (Cordillera de Nahuelbuta; Cordillera de los Andes); habits, measurements. Tamayo and Frassinetti, 1980: 327-CHILE: Nuble (Río Itata). Pearson, 1983:483-ARGENTINA: characters (scansorial, nocturnal, insectivore, omnivore).

$D$ [romiciops] australis australis, Oliver Schneider, 1946:68-CHILE: Concepción (Parque Pedro del Río; Huépil; N Río Laja).

Dromiciops gliroides Thomas, 1894:187-type description. Thomas, 1919:212-CHILE: 
Cautín (Temuco). Krumbiegel, 1941:11CHILE: Valdivia. Hershkovitz, 1992a:181, pls. III, IV (tarsal bones), pl. VIl (animal)-ankle bones, phylogeny, classification.

Dromiciops australis gliroides, Osgood, 1943: 50-CHILE: Chiloé (Quellón). Cabrera, 1958:5 - classification. Tamayo and Frassinetti, 1980:377-CHILE: Isla Chiloé (0$300 \mathrm{~m})$.

[Didelphys (Peramys)] australis, Trouessart, 1898:1244-listed.

HolotyPE-Male, skin and skull, British Museum (Natural History) M.92.9.5.3; collected 20 May 1868 by Robert O. Cunningham on the voyage of H.M.S. Nassau.

TYPE LOCALITY-Huite, near Ancud $\left(41^{\circ} 52^{\prime} \mathrm{S}, 73^{\circ} 50^{\prime} \mathrm{W}\right)$, northeastern Chiloé Island, Chile.

Distribution (Fig. 19)-The rain forests of central Chile and bordering parts of Argentina from about $36^{\circ} \mathrm{S}$ to $43^{\circ} \mathrm{S}$ on Chiloé but to $41^{\circ} \mathrm{S}$ on the mainland, or from the latitude of Concepción to the southern border of Isla Chiloé, east to the lake district of Nahuel Huapí in Neuquén, and Río Negro, Argentina. The elevational range extends from sea level in Isla Chiloé to $1450 \mathrm{~m}$ in Malleco Province.

Habitat and Associates-Dromiciops lives in the humid Nothofagus and Aracauria forests intermixed with bamboo (Chusquea) thickets. "Dromiciops was taken mostly in short-statured forests with low density of shrubs and high herbaceous groundcover, and these predominate at higher elevations" (Patterson et al., 1990, p. 630 ). In a test of elevational preferences of 10 species of small mammals (8 sigmodontines, 2 marsupials), Patterson et al. (1989) found that between elevations of 425 and $1135 \mathrm{~m}$, Dromiciops was captured most frequently at $715 \mathrm{~m}$. The animal was taken in flat, open snap traps only. The closed metal Sherman live traps were ignored.

The mean annual temperature of the Dromiciops habitat is $10^{\circ}-11^{\circ} \mathrm{C}$, the annual rainfall about 3,000-4,000 mm (Mann, 1978; Pearson \& Pearson, 1982). Dromiciops was absent in the dry matorral country in the vicinity of Santiago.

Sigmodontines captured together with Dromiciops in Greer's (1965) Malleco Province traplines were Oligoryzomys longicaudatus,
Abrothrix longipilis, Akodon olivaceus, Chelemys macronyx, Geoxus valdivianus, Loxodontomys micropus, Irenomys tarsalis, and Octodon bridgesi. Chelemys, Geoxus, or the Octodon could have excavated the tunnel described below by Greer.

Pearson \& Pearson (1982) censused small mammals in three study sites in the Parque Nacional Nahuel Huapí, Río Negro Province, in the southern rain forests of Argentina. All sites were dominated by the southern beech Nothofagus and bamboo Chusquea. The Puerto Blest study site of 1.01 ha at $770 \mathrm{~m}$ elevation, and annual rainfall of about $3,000 \mathrm{~mm}$ yielded four sigmodontine genera (Irenomys tarsalis, Geoxus valdivianus, Abrothrix longipilis, Oligoryzomys longicaudatus), Rattus sp., and the marsupial Dromiciops. Excluding Rattus, the single Dromiciops and Geoxus were least trapped. Irenomys (5.1 per ha) and Akodon (3.9 per ha) were most abundant. Trapping was during May and November 1978 and April 1980.

The second site (Río Castaño) was about 20 $\mathrm{km} \mathrm{S}$ of the first, at $950 \mathrm{~m}$ elevation, 2,000 mm annual precipitation, with freezing temperatures registered during every month of the year. Poorest catches for the site were Dromiciops (0.5 per ha) in November 1978 and Oligoryzomys longicaudatus (0.3 per ha) in May 1978. Highest yield was Chelemys macronyx (14.7 per ha) in May 1978. Other captures were Geoxus valdivianus, Akodon olivaceus, Abrothrix longipilis, and Loxodontomys micropus.

The third site was at Nire, about $43 \mathrm{~km}$ SSW of Bariloche, at about $1030 \mathrm{~m}$. Dromiciops was not found and may not occur there. A species each of Geoxus, Chelemys, Akodon, Abrothrix, and Loxodontomys were found, the same captured at the second site.

An unreported collection from Isla Chiloé and Osorno Province made by Patterson and Gallardo (1984, field catalog at FMNH) includec the same Dromiciops associates noted, in addition to Abrothrix sanborni and the caenolestic Rhyncholestes raphanurus.

Reported from La Picada, Osorno, by Mes. erve et al. (1988) were Dromiciops gliroides Rhyncholestes raphanurus, and Abrothrix san. borni, in addition to those species already men. tioned.

The poor showing of Dromiciops in the Ar gentine localities may not reflect the true population density throughout the year and in othes parts of its range. Dromiciops is morphologi 


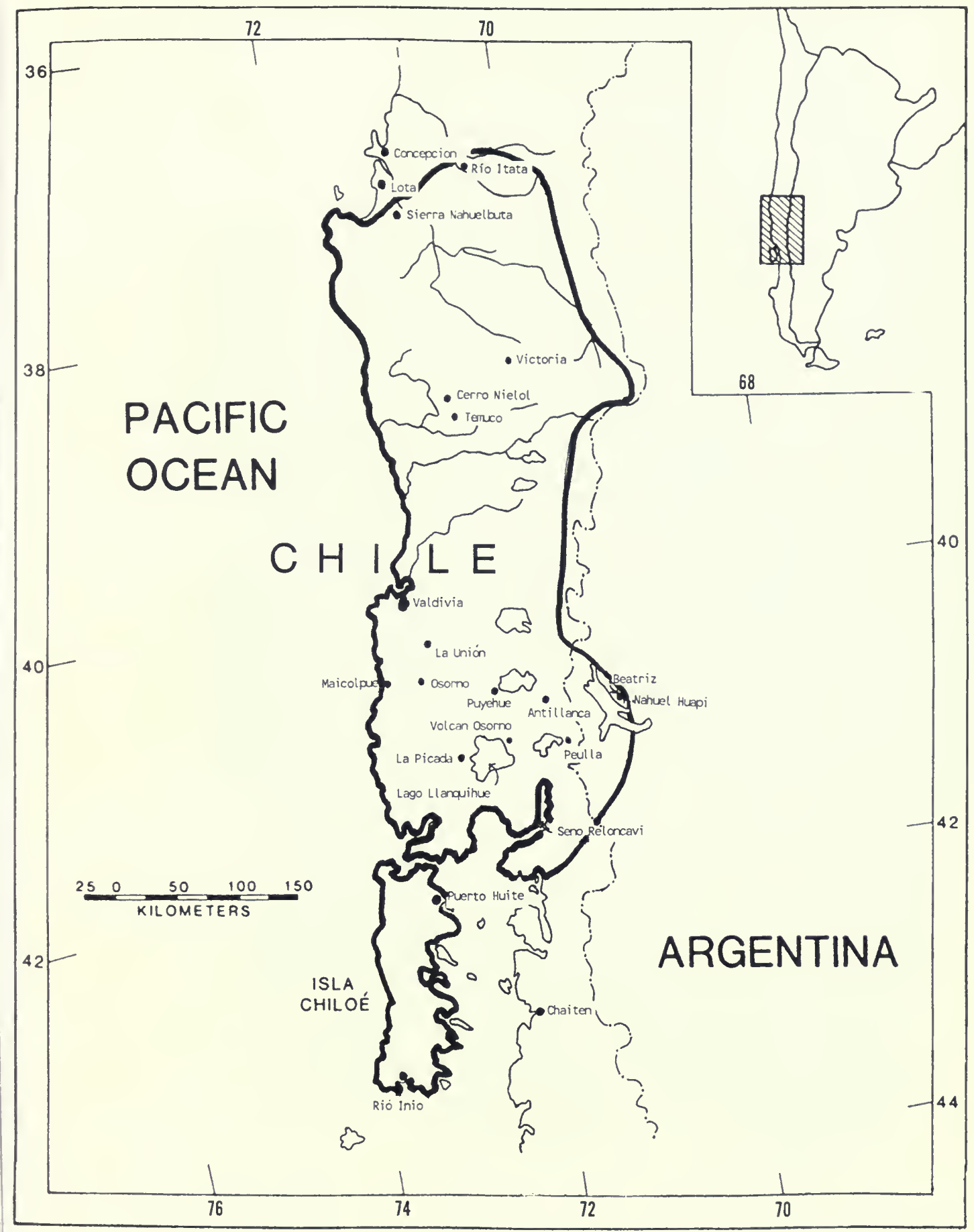

FIG. 19. Distribution of Dromiciops gliroides in Chile and bordering Argentina. See gazetteer (pp. 56-57) for geographic and political data. 

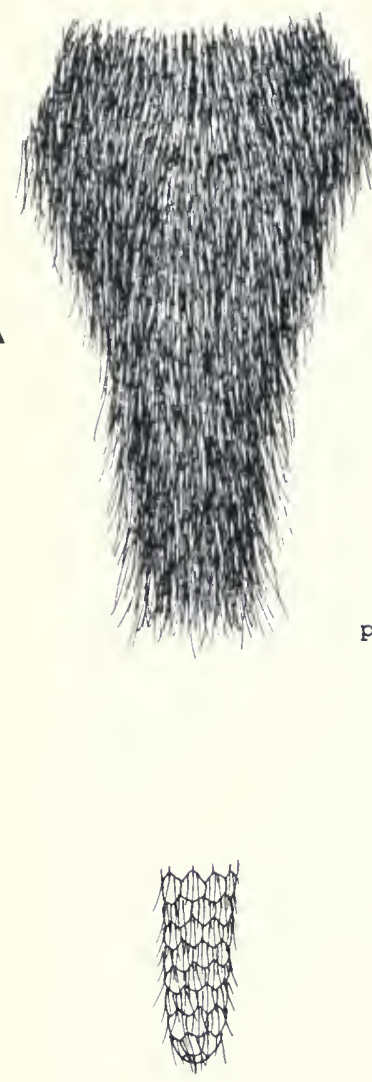

\section{B}

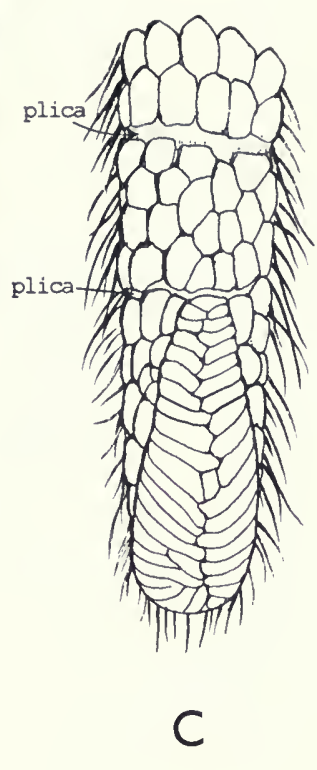

A
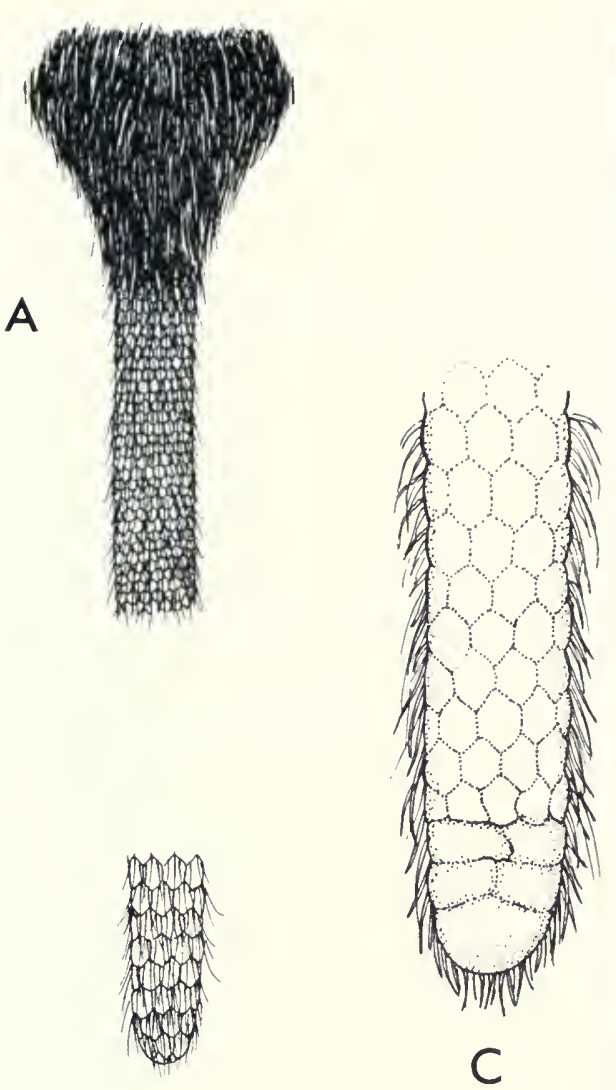

B

\section{Metachirus nudicaudatus}

FIG. 20. Tails (sections enlarged, not to scale). Left: Prehensile tail of Dromiciops gliroides. A, Dorsal surface at base. B, Terminal portion of same. C, Ventral surface of terminal portion enlarged showing dermal plica permitting folding. Right: Nonprehensile tail of Metachirus nudicaudatus. A, Base of dorsal surface, brush short. B, Terminal portion of tail. C, Ventral surface of terminal portion, dermal plica absent.

cally, physiologically, ecologically, and behaviorally different from the rodents where both were trapped.

\section{Characters}

Outer Parts and Coloration (Frontispiece)Tail prehensile, the dermal folds well marked (Fig. 20); pollex and hallux opposable (Fig. 21); pelage dense, color pattern agouti; dorsum dominantly chocolate brown, sides of trunk with a contrasting pale patch on each shoulder, postscapula, hip and rump; underparts from chin to cloaca pale ochraceous to buffy or nearly white, the gray hair bases showing through; inner sides of arms and legs like underparts, outer sides brown like sides of trunk; face (Fig. 13) buffy to ochraceous, muzzle darker, eye ring blackish, the color often extending as a dark, contrasting band across cheek to tip of nose; pale patch present above each eye; fine mystacial vibrissae extending to ears when laid back (Fig. 13); ears comparatively short, base rounded tapering to tip, thinly hirsute on inner and outer surfaces, bushy at base; hands and feet (Fig. 21) above whitish, the digits fringed; digital tufts of feet usually thick, often hiding claws; tufts of manual digits short, thin, hardly visible, claws not protruding beyond pads; pedal claws slightly or not protruding; tail (Fig. 20) slightly longer than head and body combined, prehensile, thickly pilose, proximal 4 th or 5 th incrassate, ventral sur- 

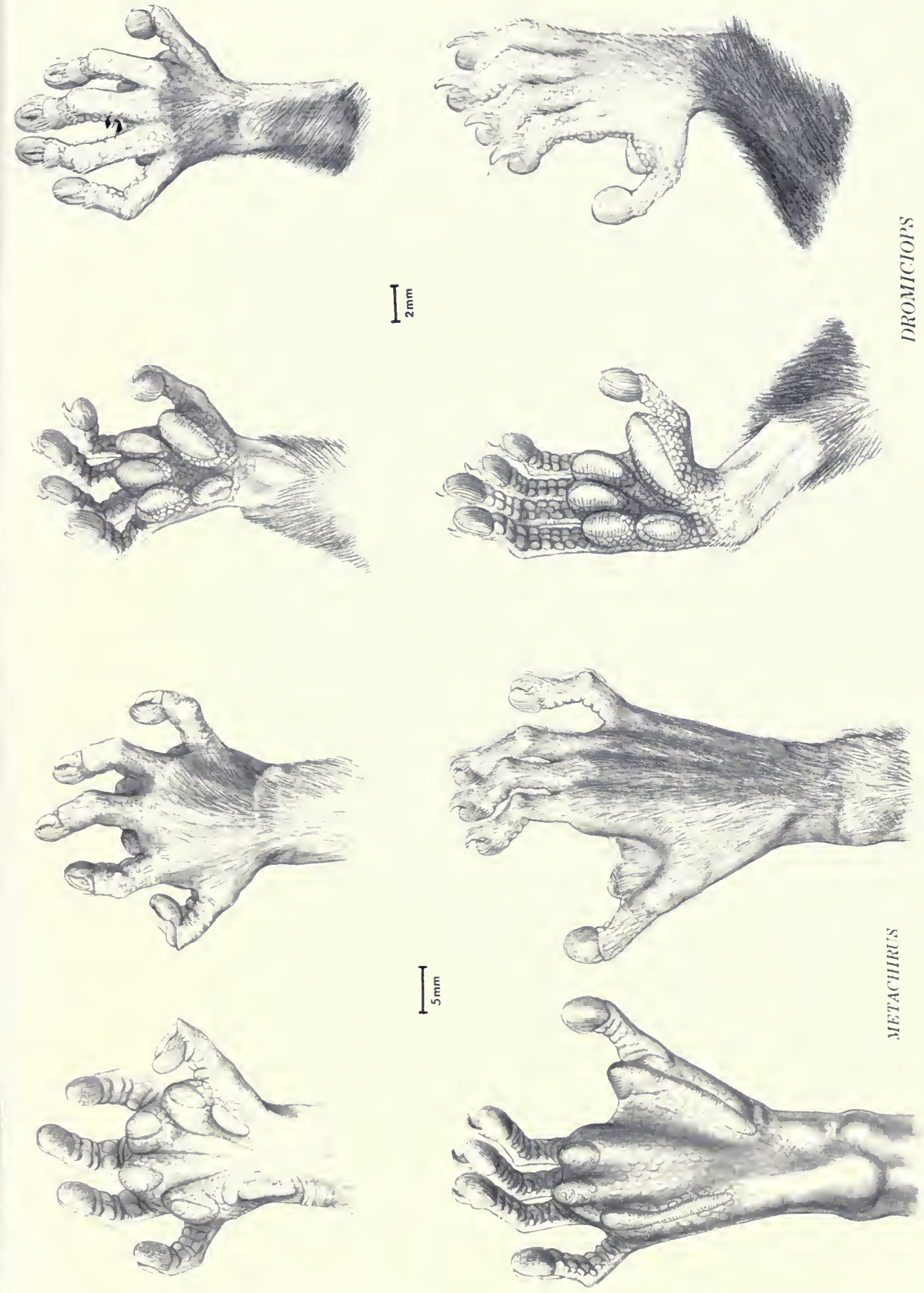

$\approx$

․ㅡ․

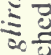

.

垔

응

5

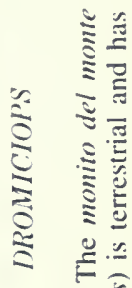

)

.

凉

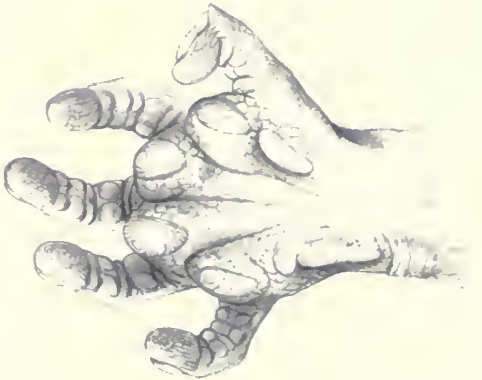


TABLE 1. Dromiciops gliroides: means and extremes $(\mathrm{mm})$ of external, cranial, and dental measurements of 2540 individuals.

\begin{tabular}{|c|c|c|c|c|}
\hline Sex & Character & Mean (extremes) & $\mathbf{N}$ & \\
\hline $\begin{array}{l}00 \\
0 \% \\
90\end{array}$ & $\begin{array}{l}\text { Total length } \\
\text { Total length }\end{array}$ & $\begin{array}{l}208(192-222) \\
212(202-229) 2\end{array}$ & $\begin{array}{l}18 \\
12\end{array}$ & \\
\hline $\begin{array}{l}0 \\
00 \\
0 \%\end{array}$ & $\begin{array}{l}\text { Head and body (HB) } \\
\text { Head and body }\end{array}$ & $\begin{array}{l}100(88-116) \\
103(9 !-116)\end{array}$ & $\begin{array}{l}18 \\
11\end{array}$ & \\
\hline $\begin{array}{l}00 \\
00 \\
9 \\
9\end{array}$ & $\begin{array}{l}\text { Tail }(\mathrm{T}) \\
\text { Tail }\end{array}$ & $\begin{array}{l}107(94-114) \\
111(101-119)\end{array}$ & $\begin{array}{l}18 \\
11\end{array}$ & $\mathrm{~T} / \mathrm{HB}=107 / 108$ \\
\hline $\begin{array}{l}00 \\
0 \% \\
90\end{array}$ & $\begin{array}{l}\text { Hind foot }(\mathrm{HF}) \\
\text { Hind foot }\end{array}$ & $\begin{array}{l}17.5(16-20) \\
18.4(17-20)\end{array}$ & $\begin{array}{l}18 \\
11\end{array}$ & $\mathrm{HF} / \mathrm{HB}=17.5 / 17.9$ \\
\hline $\begin{array}{l}00 \\
0 \% \\
90\end{array}$ & $\begin{array}{l}\text { Ear }(\mathrm{E}) \\
\text { Ear }\end{array}$ & $\begin{array}{l}17.6(16-19) \\
17.4(16-20)\end{array}$ & $\begin{array}{l}16 \\
11\end{array}$ & $\mathrm{E} / \mathrm{HB}=17.1 / 16.9$ \\
\hline $\begin{array}{l}00 \\
00 \\
90\end{array}$ & $\begin{array}{l}\text { Weight (mass), grams } \\
\text { Weight (mass), grams }\end{array}$ & $\begin{array}{l}26.1(19.2-39.5) \\
27.5(21.5-37.0)\end{array}$ & $\begin{array}{r}16 \\
9\end{array}$ & \\
\hline $\begin{array}{l}00 \\
00 \\
90\end{array}$ & $\begin{array}{l}\text { Greatest skull length } \\
\text { Greatest skull length }\end{array}$ & $\begin{array}{l}28.1(26.6-29.4) \\
28.1(27.5-29.3)\end{array}$ & $\begin{array}{l}17 \\
14\end{array}$ & \\
\hline $\begin{array}{l}00 \\
9 \%\end{array}$ & $\begin{array}{l}\text { Condylobasal length } \\
\text { Condylobasal length }\end{array}$ & $\begin{array}{l}26.8(25.4-28.4) \\
26.8(25.8-28.3)\end{array}$ & $\begin{array}{l}17 \\
14\end{array}$ & \\
\hline $\begin{array}{l}0 \\
00 \\
00\end{array}$ & $\begin{array}{l}\text { Zygomatic breadth } \\
\text { Zygomatic breadth }\end{array}$ & $\begin{array}{l}15.9(14.8-16.9) \\
16.0(15.1-17.2)\end{array}$ & $\begin{array}{l}17 \\
14\end{array}$ & \\
\hline $\begin{array}{l}00 \\
90 \\
9\end{array}$ & $\begin{array}{l}\text { Interorbital breadth } \\
\text { Interorbital breadth }\end{array}$ & $\begin{array}{l}5.0(4.6-5.2) \\
4.9(4.7-5.4)\end{array}$ & $\begin{array}{l}17 \\
14\end{array}$ & \\
\hline $\begin{array}{l}00 \\
00 \\
9\end{array}$ & $\begin{array}{l}\text { Postorbital breadth } \\
\text { Postorbital breadth }\end{array}$ & $\begin{array}{l}7.8(7.3-8.5) \\
7.7(7.2-8.8)\end{array}$ & $\begin{array}{l}10 \\
11\end{array}$ & \\
\hline $\begin{array}{l}00 \\
90 \\
9\end{array}$ & $\begin{array}{l}\text { Braincase width } \\
\text { Braincase width }\end{array}$ & $\begin{array}{l}12.2(12.0-12.9) \\
12.6(11.9-13.1)\end{array}$ & $\begin{array}{l}18 \\
14\end{array}$ & \\
\hline $\begin{array}{l}0 \\
00 \\
9 \\
9\end{array}$ & $\begin{array}{l}\text { Nasals length } \\
\text { Nasals length }\end{array}$ & $\begin{array}{l}10.2(9.5-10.9) \\
10.4(9.7-11.2)\end{array}$ & $\begin{array}{l}18 \\
14\end{array}$ & \\
\hline $\begin{array}{l}0 \\
00 \\
9 \\
9\end{array}$ & $\begin{array}{l}\text { Palate length } \\
\text { Palate length }\end{array}$ & $\begin{array}{l}13.5(12.2-14.6) \\
13.4(12.7-14.7)\end{array}$ & $\begin{array}{l}17 \\
14\end{array}$ & \\
\hline $\begin{array}{l}00 \\
00 \\
0 \\
9\end{array}$ & $\begin{array}{l}\text { Interparietal width } \\
\text { Interparietal width }\end{array}$ & $\begin{array}{l}9.2(8.6-10.9) \\
8.9(8.0-9.4)\end{array}$ & $\begin{array}{l}17 \\
14\end{array}$ & \\
\hline $\begin{array}{l}00 \\
0 \\
9\end{array}$ & $\begin{array}{l}\text { Interparietal length } \\
\text { Interparietal length }\end{array}$ & $\begin{array}{l}3.0(3.0-4.4) \\
3.9(3.3-4.7)\end{array}$ & $\begin{array}{l}17 \\
14\end{array}$ & \\
\hline $\begin{array}{l}01 \\
00 \\
9 \\
9\end{array}$ & $\begin{array}{l}\text { Dental series }\left(i^{1}-m^{4}\right) \\
\text { Dental series }\left(i^{1}-m^{4}\right)\end{array}$ & $\begin{array}{l}12.5(11.9-13.4) \\
12.6(12.3-13.2)\end{array}$ & $\begin{array}{l}17 \\
14\end{array}$ & \\
\hline $\begin{array}{l}00 \\
9 \% \\
9\end{array}$ & $\begin{array}{l}\text { Molar row }\left(\mathrm{m}^{1-4}\right) \\
\text { Molar row }\left(\mathrm{m}^{1-4}\right)\end{array}$ & $\begin{array}{l}4.8(4.1-5.4) \\
4.8(4.6-5.2)\end{array}$ & $\begin{array}{l}17 \\
14\end{array}$ & \\
\hline $\begin{array}{l}00 \\
\wp \wp\end{array}$ & $\begin{array}{l}\text { Across } \mathrm{m}^{3-3} \\
\text { Across } \mathrm{m}^{3-3}\end{array}$ & $\begin{array}{l}9.3(8.6-9.5) \\
9.2(8.9-9.7)\end{array}$ & $\begin{array}{l}17 \\
14\end{array}$ & \\
\hline $\begin{array}{l}00 \\
0 \%\end{array}$ & $\begin{array}{l}\text { Across bullae } \\
\text { Across bullae }\end{array}$ & $\begin{array}{l}12.1(11.6-13.1) \\
12.4(11.7-13.5)\end{array}$ & $\begin{array}{l}17 \\
14\end{array}$ & \\
\hline
\end{tabular}

face paler than dorsal, terminal 4th or 5 th beneath bare, scales annular; mammary field with 4 exposed nipples (Fig. 14), the area rimmed reddish in mature females; gular gland present; cloaca basicaudal, prepenial scrotum whitish, its peduncle comparatively short (Fig. 12).

Measurements-Individual external, cranial, and dental measurements of specimens examinec are given in Table 1.

BODY SIZE-External dimensions $(\mathrm{mm})$ of $\epsilon$ specimens from Parque Nacional de Nahuel Huapí recorded by Santos (1946, p. 192) are the following. Head and body, $108(90-120)$; tail, 117 (105-132); hind foot 16 (15-17); ear 14 (12-16) 
Compared with the FMNH material (Table 1), the Santos series has a larger body and a longer tail, but significantly smaller hind feet and shorter ears. There is no accounting for the discrepancies even if the smaller foot measurement given was without claw, and the shorter ear measured from crown, not notch.

Local or geographic size differences are expected. Greer (1965, p. 104) recorded the following measurements $(\mathrm{mm})$ from two localities in Malleco Province, sexual size differences not evident:

\begin{tabular}{|c|c|c|}
\hline & $\begin{array}{l}\text { Cordillera } \\
\text { Nahuelbuta } \\
\text { (6 adults) }\end{array}$ & $\begin{array}{c}\text { Cordillera } \\
\text { de los Andes } \\
\text { (17-20 adults) }\end{array}$ \\
\hline ad and body & $101.3(96-109)$ & $107.9(83-113)$ \\
\hline & $107.7(101-116)$ & $99.7(90-115)$ \\
\hline$d$ foot & $19.7(19-20)$ & $19.3(16-20)$ \\
\hline & $19.0(18-20)$ & $18.7(17-20)$ \\
\hline $\begin{array}{l}\text { ondylobasal } \\
\text { length }\end{array}$ & $26.4(25.5-27.9)$ & $25.7(23.6-27.5)$ \\
\hline $\begin{array}{l}\text { gomatic } \\
\text { breadth }\end{array}$ & $15.6(14.6-16.1)$ & $15.6(14.4-16.4)$ \\
\hline $\begin{array}{l}\text { terorbital } \\
\text { breadth }\end{array}$ & $4.8(4.5-4.9)$ & $4.9(4.7-5.1)$ \\
\hline ight (g) & $24.1(21.3-28.1)$ & $22.3(16.7-31.4)$ \\
\hline
\end{tabular}

An excessively fat male collected by Patterson (field notes) in Osorno weighed $49 \mathrm{~g}$. Consistent color differences between the Greer populations were not evident. The Santos and Greer data are slightly larger overall than the FMNH material (Table 1).

Growth And Development-A nest with mother and 4 young found by Jiménez and Rageot (1979) was taken to the laboratory for observation. Estimated age of the young was 2 months. Capture date was 2 February 1978. Pelage of the pups was short, thin, and reddish; the still-closed eyes were circled black, as in adults (Plate 2). Dimensions (in $\mathrm{mm}$ ) of mother and 2 young were as follows:

\begin{tabular}{lcrr} 
& Head and Body & & Tail \\
\cline { 2 - 2 } Mother & 110 & & 105 \\
ot young & 33 & & 36 \\
\& young & 34 & & 35
\end{tabular}

Chronology of Growth and Development:

2 February-capture date; estimated age, 2 months.

2-9 February-attached to nipples.

10-17 February-nipples released from time to time.
13 February-eyes opened by one young.

14 February - eyes opened by second young; both partook of melon, banana; moved in and out of nest independently.

6 March-molt began.

22 March-molt completed; suckling continued; adult diet increased.

When nest was outgrown, young rode on mother's back.

Growth among marsupials, particularly the smaller species, is continuous, but few individuals survive more than 2 years in the wild, judged by measurements.

Dromiciops attains sexual maturity in its second year (Mann, 1978). It has never been bred in captivity.

LONGEVITY - The longest-lived monito del monte recorded by Jiménez and Rageot (1979) survived 2 years and 2 months in captivity. The animal may have been at least 1 year old when captured.

Sexual Dimorphism-Present material shows no recognizable differences between adult males and females in external characters other than those of reproduction and some skeletal characters. Among didelphoids and caenolestoids, males are usually significantly larger and heavier than females, canines larger.

TESTIS (Figs. 9-11)-The seminiferous tubules, rete testis, and efferent ducts of Didelphis albiventris, Philander opossum, Marmosa sp., Caluromys derbianus, Caenolestes fuliginosus, and Dromiciops gliroides were examined by Woolley (1987). Data and conclusions from Woolley (1987) and Rodger (1982) are principal sources of what follows. Those of the didelphoids, caenolestids, and Dromiciops appeared to resemble the simple duct system of the Australian Dasyuridae. Thylacinidae, Myrmecobiidae, Peramelidae, and Tarsipedidae, ostensibly the primitive state. The rete system of the Phalangeridae and Macropodidae was complex and horseshoe-shaped, evidently derived.

The forms of the testis and epididymis and connecting ducts in the caenolestid and didelphoids examined have been illustrated and described by Rodger (1982) and Woolley (1987); my Figure 11, copied from Woolley, shows the efferent duct system and epididymis of Dromiciops among others. Woolley (1987) found no obvious pigmentation of the scrotal skin in Dromiciops, but both the parietal and visceral layers of the tunica vaginalis contained black pigment. The diameters of 
the seminiferous tubules in sexually mature didelphoids and caenolestids examined ranged from 0.17 to $0.27 \mathrm{~mm}$. The tubule of Dromiciops, however, was too young to measure. Woolley (1987) could confirm that in the didelphoids and caenolestids observed by Rodger (1982), the rete is a simple duct system lying within the testicular tissue in the anterior pole of the testis. A single duct was found in all of those mentioned except one Didelphis albiventris (Fig. 11), in which the main duct bifurcated. No distinct mediastinum was found in any species examined by Rodger (1982).

"In the microbiotheriid, Dromiciops, the rete [Fig. 10] ... consisted of a network of interconnected channels lying among the seminiferous tubules in the anterior pole of the testis. It was encased in a thin but distinct mediastinum formed as an inturning of the fibrous tissue of the tunica albuginea. After penetrating the testicular tissue for a short distance the rete branched into two, one branch being a little shorter than the other" (Woolley, 1987, p. 220).

In Dromiciops, the number of tubuli recti (36 to 41 ) is greater than the number found in didelphoids (6 to 32) and caenolestids (10). The number of tubuli is variable, however, and the Dromiciops specimen was immature.

Diameter of tubules, form of rete, depth of penetration, length of main duct and number of tubuli are shown in Table 2.

"The seminiferous tubules of Dromiciops appeared to be highly coiled and the intertubular spaces filled largely with Leydig cells. No lobulation was apparent. The animal was judged to be sexually immature because most of the tubules were without lumina and spermatogenesis had not proceeded beyond the stage of spermatocytes" (Woolley, 1987, p. 219).

"The groups with the greatest similarity in testis and rete organisation are the American didelphids and caenolestids and the Australian dasyurid, peramelid, tarsipedid, myrmecobiid and thylacinid marsupials. The American microbiotheriid Dromiciops shows some similarity (in the location of the rete in the testis) to these families but is distinct from them, and from other Australian families, in the structure of the rete and in the possession of a mediastinum" (Woolley, 1987, p. 226).

The morphology of the testis, as adduced by Woolley, offers convincing evidence of a significant distinction between Dromiciops and didelphoids and caenolestoids on the one hand, and an

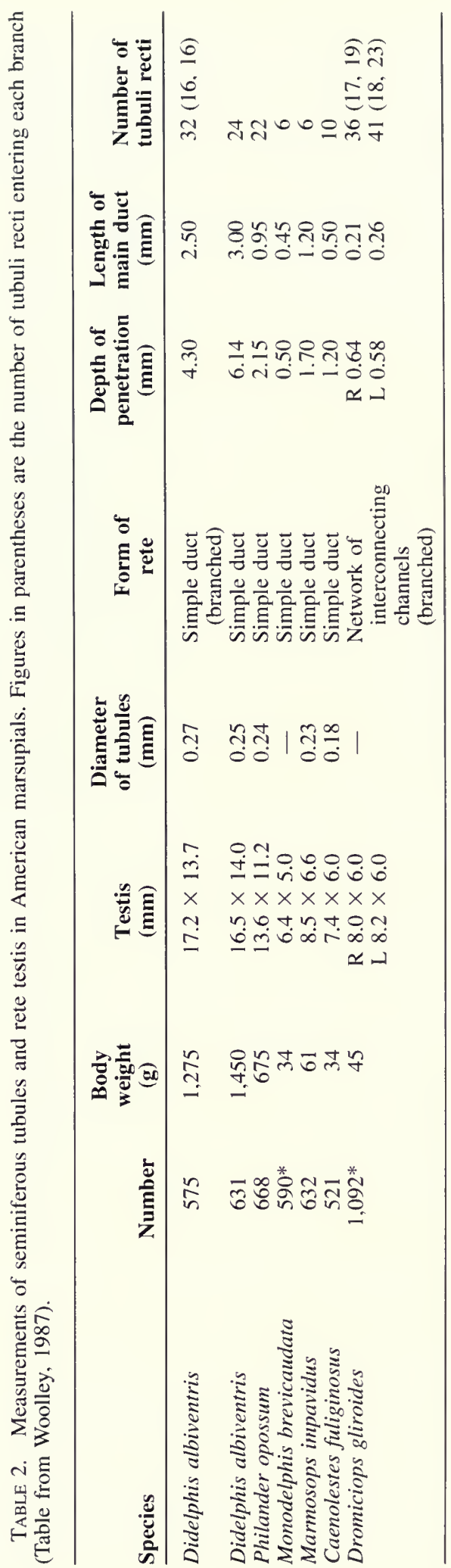


even greater separation from Australian marsupials.

SpermatozoA (Fig. 22)-Four morphological types of spermatozoa have been distinguished in American marsupials, three of them by Biggers et al. (1963) and the fourth by Temple-Smith (1987) (Fig. 22). Descriptions of the first three are summarized from Biggers (1966, p. 269), that of Dromiciops from Temple-Smith (1987, pp. 180-182).

Didelphis Type-Head flattened, hook-shaped, with two backwardly directed limbs, one thick, the other thinner, longer, tapered; acrosome on anterior part of thick limb; midpiece attached by fine filament to base of cleft separating limbs of head: Didelphidae (Didelphis, Philander, Chironectes); Marmosidae (Marmosa); Monodelphidae (Monodelphis); Metachiridae (Metachirus); spermatozoa paired.

Caluromys Type-Head saucer-shaped, acrosome on concave side; midpiece inserted in center of convex side of head: Caluromyidae (Caluromys); spermatozoa paired.

Caenolestes Type-Head cleft on one side into which midpiece is inserted; acrosome not studied: Caenolestidae (Caenolestes); spermatozoa paired.

Dromiciops Type-Head cuneiform, acrosome restricted to anterior third of dorsal surface of nucleus, midpiece not preserved; spermatozoan pairing not determined; the single head said to be similar to that of Australian Trichosurus vulpecula (Phalangeridae).

PAIRING-The swimming of spermatozoa in closely coupled pairs as a regular phenomenon has been observed in the epididymides and in mated females of all the genera mentioned above except Dromiciops. The pairing involves juxtaposition at the acrosome level of the heads of two spermatozoa. According to Biggers (1966), the principal source of this information, spermatozoan pairing has not been observed in Australian marsupials. This may well be one of the most significant differences separating all living Australian marsupials from American didelphoid opossums and paucituberculates.

Relationships between American and Australian marsupials based on sperm morphology, maturation, and pair formation was discussed by Temple-Smith (1987). Biggers suggested that

sperm pairing, also regarded as a feature of sperm mat- uration, is restricted to the American marsupial fauna and has been used to separate them from their Australian counterparts. The evidence provided suggesis sperm pairing will occur in all those American species not yet examined, such as Lestodelphys, Lutreolina, Caluromyciops [sic], Glironia, Lestoros and Rhyncholestes, with the exception perhaps of Dromiciops, which has sperm which more closely resemble those of Australian marsupials.

Temple-Smith (1987, p. 180), added that

recent observations on sperm structure, and in particular sperm head morphology have cast more light on the evolutionary affinities of this species [Dromiciops gliroides]. ... Although these ultrastructural observations .. have been made on inappropriately fixed, field material, sufficient detail is present in spermatozoa from the cauda epididymidis to indicate a remarkable similarity in sperm head structure between Dromiciops ... and many Australian species.... In fact, with material appropriately prepared for electron microscopy, it would probably be difficult to readily distinguish the sperm head of Dromiciops from such species as Trichosurus vulpecula. Cercartetus namus and some other related possum species. ... The structural features which characterize these species ... are all features shared by Dromiciops spermatozoa ... but not by those of any other extant American species.

In Didelphis, according to Rodger (1982, p. 269) "paired ejaculated spermatozoa are transported to the oviducal isthmus where they separate, and fertilization is monospermic."

Didelphoid sperm pairing is clearly a derived condition, unique among mammals but unproven in Dromiciops. The condition evolved after separation of Australian marsupials from their American progenitor(s), which, at the time, still possessed the simple ancestral type of epididymal sperm, at least in the Antarctic Sounders. Any similarity between sperm morphology of living Dromiciops and living Australian marsupials may be attributed to retention of the relevant primitive character state in both taxa.

Marsupia And Mammary Field (Fig. 14)Marsupials were so named under the mistaken belief that all were characterized by an abdominal or abdomino-inguinal pocket containing the mammary glands suckled by sheltered young. Australian marsupials, with few exceptions, have pouches. The majority of New World marsupials lack them. An abdomino-inguinal cutaneous pocket housing milk glands is possessed by females of the marsupial families Didelphidae (Didelphinae [Philander, 2 species; Didelphis, 3 species]; Chironectinae [Chironectes, 1 species]; Lutreolininae [Lutreolina, 1 species]), Caluromyidae (Caluro- 


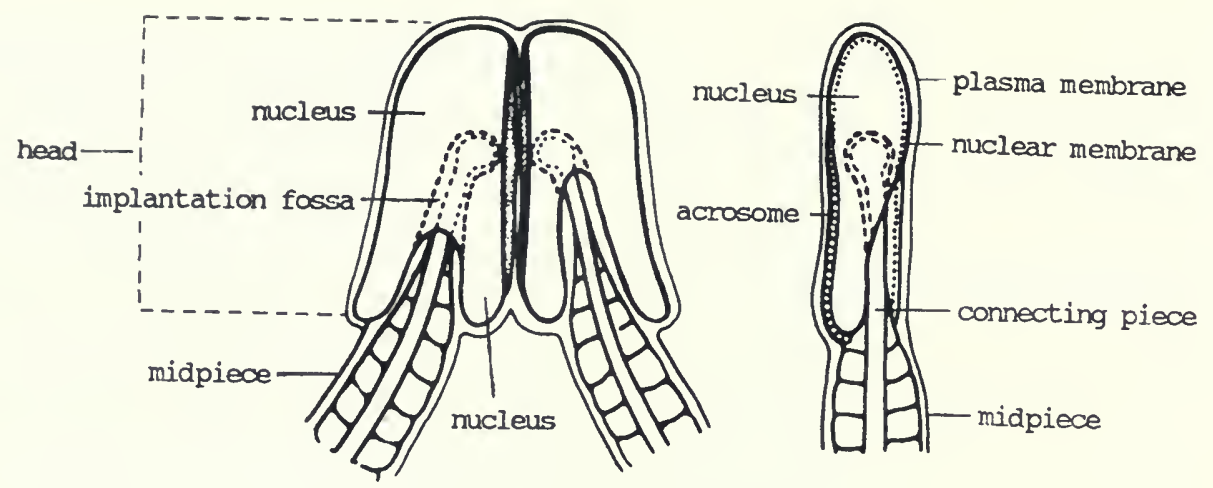

Didelphis type
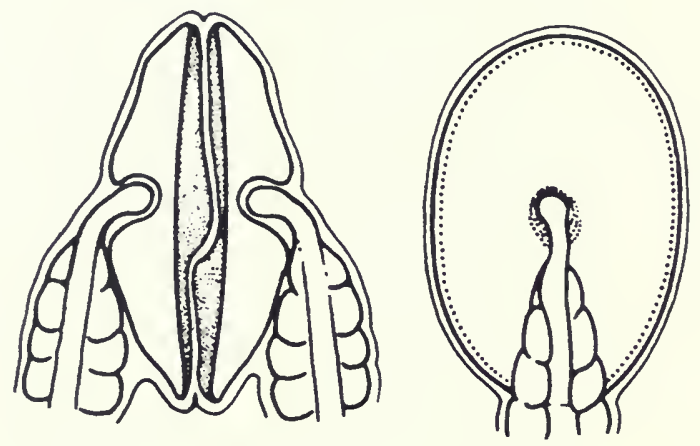

Caluromys type
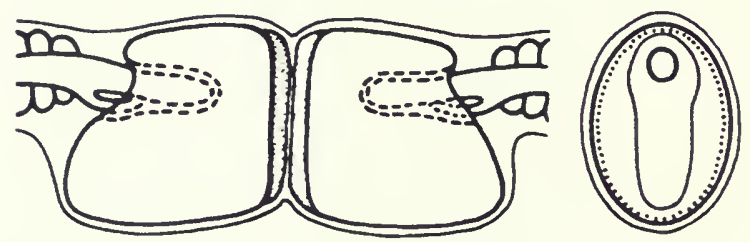

Caenolestes type
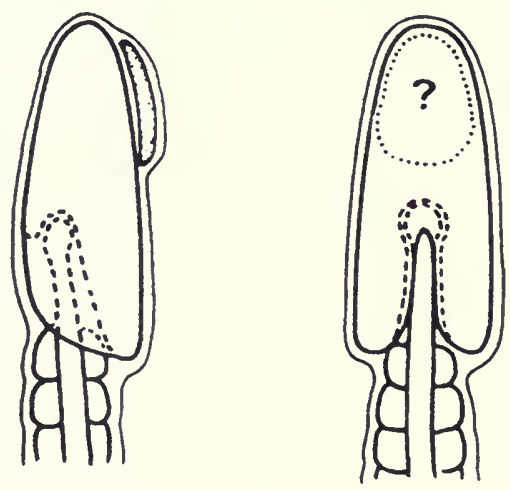

Dromiciops type 
mys, 3 species; Caluromysiops, 1 species), Glironiidae (Glironia, 1 species, not a caluromyid, has no pouch), and Microbiotheriidae (Dromiciops, 1 species with pouch). Marsupium and scrotum are not homologous.

The pouch or pocket is composed of a pair of recessed longitudinal skin folds, one on each side of the midabdomino-inguinal region. In didelphoids they are united caudally but separate proximally. In Didelphis, the lip of each lateral skin fold is known to appose the other to form a completely but flexible shuttered waterproof pocket for shielding the suckling young (cf. Enders, 1937, p. 25: 1966, p. 199). The folds of Chironectes are similar.

The pouch of Dromiciops gliroides consists of an ovate midabdominal orange or reddish mammary field roughly $10 \times 15$ to $13 \times 20 \mathrm{~mm}$ in mature females. The field is partially shielded by a pair of lateral cutaneous folds, one on each side, joined caudally in a recessed pocket but separated laterally, leaving exposed the pair of abdominal nipples on each side. The lateral cutaneous folds are recessed a millimeter or two on each side, about $1 \mathrm{~mm}$ deeper caudally. The central mammary field is swollen when filled with milk.

The maximum 4 young of Dromiciops may not need the protection provided by apposing lateral folds such as those of Didelphis. The Chusquea nest built for them by the pregnant mother is well hidden and waterproof when covered with moss or bryophytes. The survival rate of young may be high and compare favorably with that of didelphoids with much larger litters.

Didelphoids other than those mentioned above are pouchless. The mammae are arranged bilaterally, in some extending from inguinal to pectoral regions, in others not beyond the abdomen. In most species there may be 1 , rarely a few, additional nipples in the medial abdominal region. The number of nipples in didelphoids ranges from 5 to 7 in Marmosops impavidus to 27 in Monodelphis henseli, the total in each species being odd (Hershkovitz, 1992b, Table 1, pp. 14-15).

The marsupium must have arisen independently in each group. Among Monotremata, the spiny anteaters (Tachyglossus) develop a temporary pouch for incubation of usually 1, occasionally 2 eggs. The platypus (Ornithorhynchus) has no pouch. An abdominal pouch is no more plesiomorphic in Prototheria than in Metatheria.

Six types of mammary fields defined by the nipple pattern, all even-numbered, are described and illustrated by Tyndale-Biscoe and Renfree (1986, p. 38). Number 1 is ovate with limits of the "pouch area," or mammary field, outlined diagrammatically. The field "has no covering fold of skin" and the (10) nipples are fully exposed. This type is said to be representative of "Didelphidae, Caenolestidae. Dasyuridae." No American marsupial mammary field conforms to it or to any of the other types outlined. The types (1-4) shown by Tyndale-Biscoe and Renfree (1986) were copied from Woolley (1974, p. 12), who had constructed them from dasyurid models. American types were not mentioned. There is, however. a superficial resemblance of type I to the 4-nipple mammary field of Dromiciops (Fig. 14).

Reproductive System (Fig. 23)-The female reproductive system of Dromiciops is the normal marsupial type characterized by medial ureters, double vaginas, and a middle or pseudovagina for delivery of young. The system in Dromiciops as seen and illustrated by Mann (1958, p. 209; 1978. p. 28) is reproduced here (Fig. 23). The male reproductive system of the species has not been seen by me. Available (FMNH) entire specimens preserved in alcohol were either too young or had been deprived of their genitalia by an unknown pursuer of knowledge.

REMARKS-According to Mann (1958, p. 209), the scrotal color changes from whitish in young to bright dark red in adults. In 22 males at hand, of various ages and from several localities, neither scrotum nor other abdominal part or area is reddish. In 16 females the mammary field is orange or yellowish to reddish in 7 full adults. including all parous individuals.

R. A. Philippi (1894, p. 35) had been informed by the person who brought him the holotype of $D$. australis that up to 5 young had been seen in a nest. This has never been verified. A 5th young could not survive for lack of a nipple, but it is not uncommon for newborns of a litter to outnumber the nipples.

FIG. 22. Diagrams of 4 types of American marsupial spermatozoa: From top to bottom: Didelphis (sperm pair. and unpaired at right). Caluromys (sperm pair, and unpaired), Caenolestes (sperm pair. and unpaired). and Dromiciops (unpaired) side and front. From Temple-Smilh (1987. p. 177); labels added. Reproduced courtesy of Surrey Beally \& Sons Pty. Ltd. 

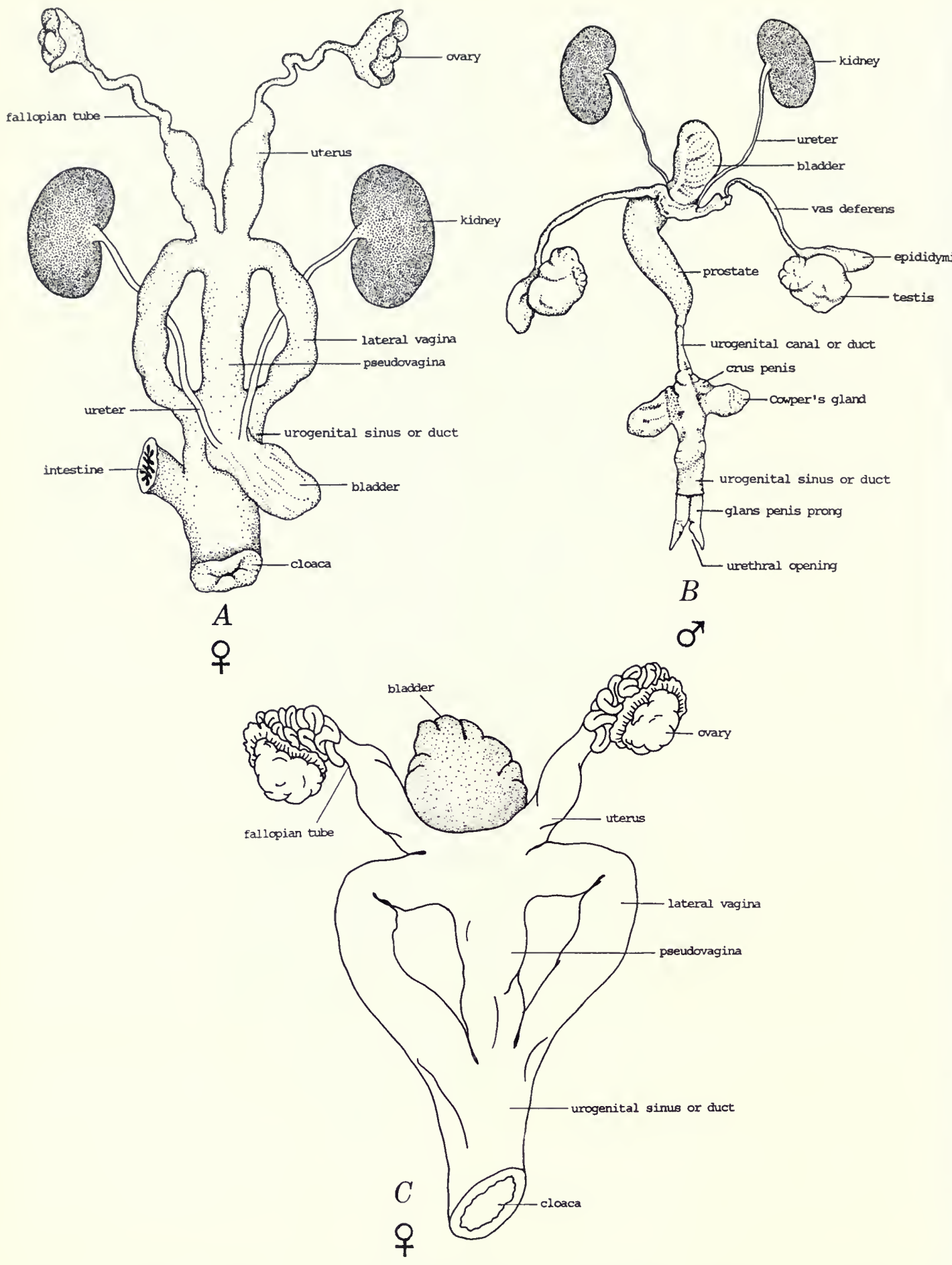

FIG. 23. Metatherian reproductive systems. A, Female $(q)$. Each independent uterus connects to the vagina $o$ the same side; each vagina empties into the urogenital sinus or duct through the pseudovagina, which serves as th birth canal for both vaginas. The pseudovagina usually disappears after parturition and re-forms for the next birth B, Male $(\delta)$. The penis is everted independently; the paired testes are external and contained in a prepucial pendulou scrotum (not shown). Diagrams based on the reproductive system of Philander opossum. C, System of $q$ Dromiciop 
BREEDING-The breeding season occurs during the southern spring. Suckling young have been recorded in November (Osgood, 1943), December (Pearson, 1983; Greer, 1965), and January (Mann, 1978). Hunsaker (1977, p. 143) states that Dromiciops "breeds October through May, pouch young in November and December" but fails to give the source of data. None of the many adult females collected by Patterson, Meserve, and Lang at La Picada during February and March 1984 harbored suckling young, although some were still lactating (Patterson, pers. comm.).

The male, according to Mann (1978, p. 35), stays with the female at least during the breeding season. This has not been verified, nor is there evidence that the marsupial male helps care for the young.

CAECUM (Fig. 18)-Aplin and Archer (1987, p. xxxvii) affirm that "Dromiciops australis shares with all of the members of two Australian orders (Dasyuromorphia and Notoryctemorphia) and with Tarsipes (alone within the Order Diprotodontia) the derived loss of an intestinal caecum (Hume 1982)."

According to Hume (1982), Australian members of the families noted by Aplin and Archer lack a caecum, but nowhere in his text is Dromiciops mentioned. This genus, like all other American marsupials described or figured by Hume (Marmosa [s.l.], Philander, Chironectes, Didelphis, Caenolestes), has an intestinal caecum. That of Dromiciops is similar (Fig. 18).

Explanation of symbols 1-28 and a-y in Figures $7,23,25$, and 26

\section{Bones}

1. nasal

2. frontal

3. parietal

4. interparietal

5. premaxillary

6. maxillary

7. lacrymal

8. jugal (zygomatic)

9. squamosal (temporal)

10. sphenoid (includes orbitosphenoid, basisphenoid)

11. palatine
12. orbitosphenoid

13. mastoid

14. presphenoid (crista)

15. basisphenoid

16. alisphenoid

17. tympanic process of alisphenoid

18. ectotympanic

19. tympanic process of periotic

20. occipital condyle

21. basioccipital

22. supraoccipital or exoccipital

23. exoccipital or supraoccipital

24. entotympanic

25. turbinates

26. pterygoid

27. vomer

28. malleus

29. incus

\section{Foramina, Fissures, Processes, Fossae, Others}

a. external nares

b. infraorbital foramen

c. lacrymal foramen (foramina)

d. canine fossa

e. posterolateral vacuity or foramen

f. postglenoid foramen

g. foramen rotundum

h. foramen ovale

i. auditory meatus and tympanic membrane

j. postglenoid process

k. jugular foramen

1. stylomastoid foramen

m. hypoglossal foramen (not condylar foramen $=$ w)

n. carotid foramen

o. anterior lacerate foramen

p. foramen magnum

q. glenoid fossa (with 9)

r. incisive foramen or premaxillary vacuity

s. maxillopalatine vacuity

t. mesolateral vacuity (coalesced with s)

u. ascending postorbital (zygomatic) process

v. frontal sinus ( 1 or 2 pairs)

w. condylar foramen (not hypoglossal canal $=\mathrm{m}$ )

$\mathrm{x}$. hamular process of pterygoid bone (26)

y. venous foramen

z. lambdoidal crest

may not differ essentially from that of $q$ Philander; diagram incomplete but all that is available. Copied from Mann (1958) with labels added; not to scale. 


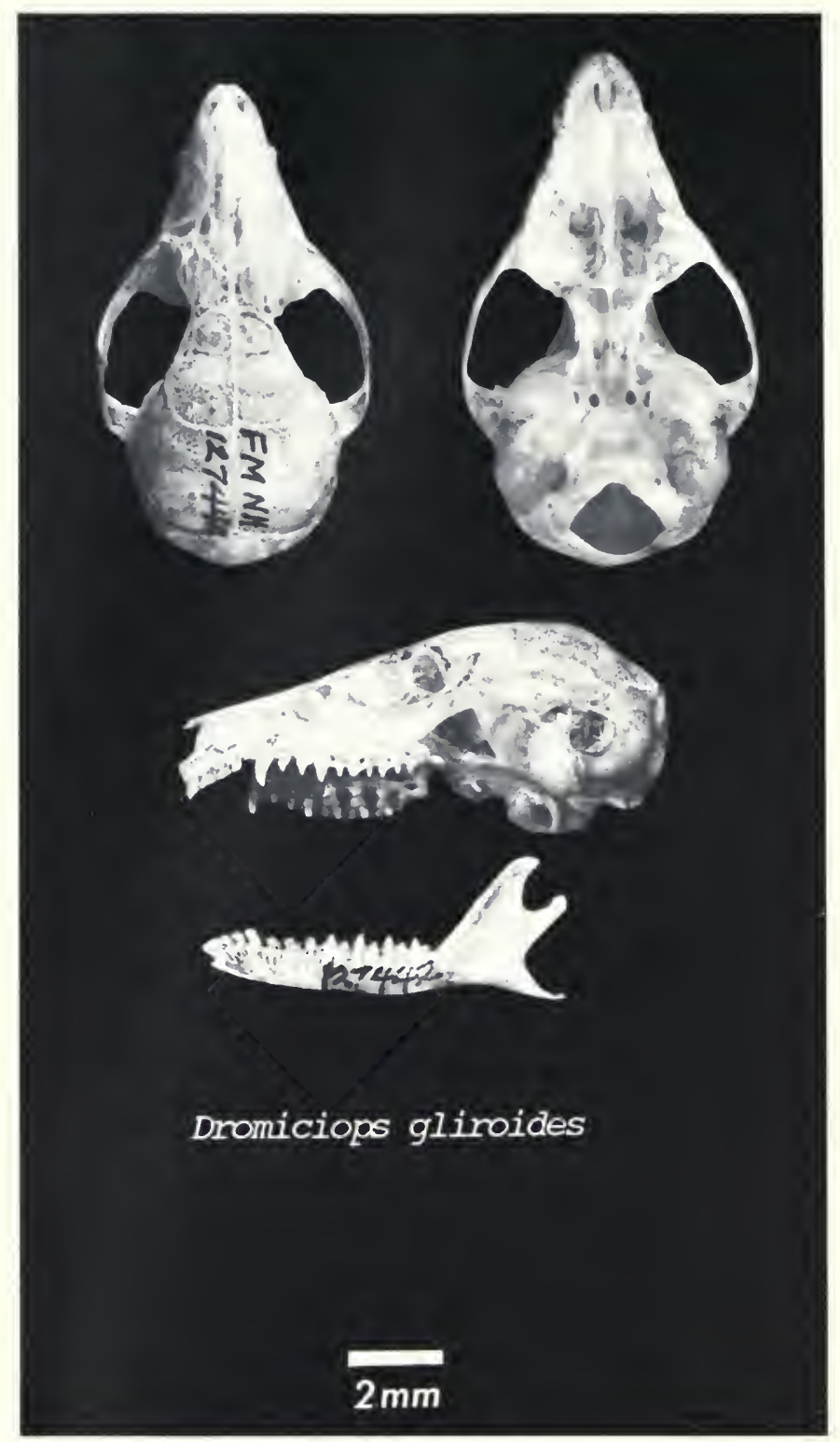

FIG. 24. Skull of Dromiciops gliroides: dorsal, ventral, and left lateral aspects; mandible below.

SkULL (Figs. 8, 24-26)-Skull broad, uncrested; braincase vaulted, temporal ridges absent; fronto-parietal suture more or less transverse; interparietal bone large; nasals flared at nasomaxillary suture; nasal tips not projected beyond distal border of premaxillary bones; inferior postorbita process sharply pointed; premaxillary symphysis comparatively shallow, more nearly rounded thar angular; incisive foramina short, not extending behind plane of canines; palate comparatively

FIG. 25. Diagrams of Dromiciops gliroides skull: 3 sides of cranium and 3 of mandible showing all elements See page 39 for key to symbols. 

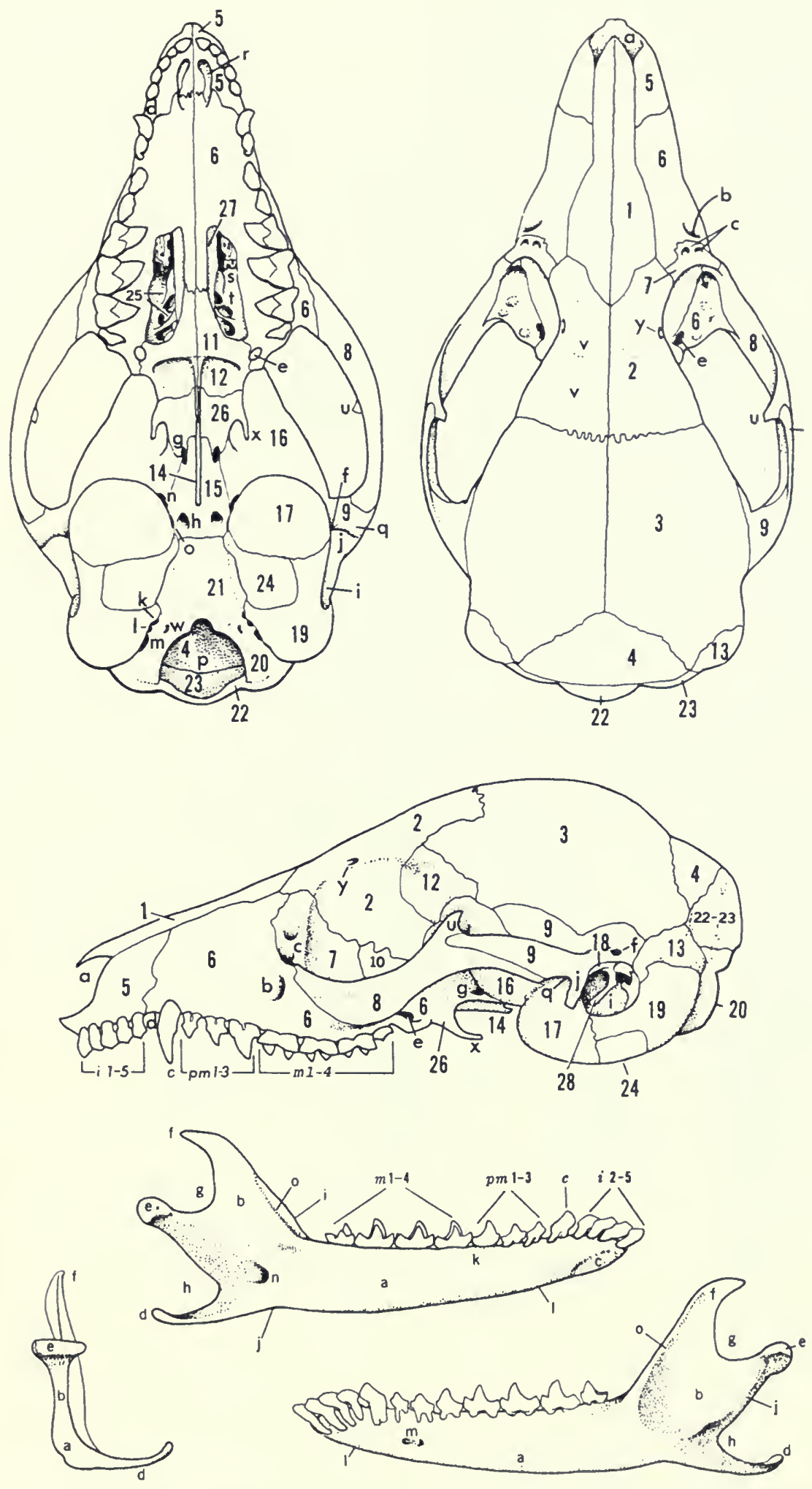
TABLE 3. Skeletal dimensions ( $\mathrm{mm}$ ) and proportions of Dromiciops, compared with three caenolestoids and one didelphoid.

\begin{tabular}{|c|c|c|c|c|c|}
\hline Name & $\begin{array}{c}\text { Greatest skull } \\
\text { length }\end{array}$ & Radius & Humerus & $\frac{\text { Radius }}{\text { Humerus }} \times 100$ & Tibia \\
\hline \multicolumn{6}{|l|}{ Caenolestidae } \\
\hline $\begin{array}{c}\text { Caenolestes } \\
\text { fuliginosus } \\
\text { Caenolestes }\end{array}$ & $29,31,34$ & $14,13,17$ & $14,14,18$ & $102,95,91$ & $23,20,22$ \\
\hline $\begin{array}{c}\text { convelatus } \\
\text { Rhyncholestes }\end{array}$ & 34 & 18 & 18 & 100 & 26 \\
\hline raplaanurus & 34 & 17 & 13 & 131 & 23 \\
\hline \multicolumn{6}{|l|}{ Marmosidae } \\
\hline $\begin{array}{l}\text { Gracilinanus } \\
\text { marica }\end{array}$ & 27.8 & 16 & 15 & 106 & 22 \\
\hline \multicolumn{6}{|l|}{ Microbiotheriidae } \\
\hline $\begin{array}{c}\text { Dromiciops } \\
\text { gliroides }\end{array}$ & $28.5(27.6-29.4) 15$ & $16.6(15-17.7) 15$ & $13.9(13.1-15) 15$ & $119.3(100-127) 15$ & $21.8(21.0-23.5) 15$ \\
\hline
\end{tabular}

${ }^{1}$ Length $=$ thoracic, lumbar, and sacral vertebrae combined.

broad; maxillopalatine and posteromedial vacuities coextensive, combined length extends from about level of pm3 to posterior palatal rim; mesopterygoid fossa divided by a unique presphenoidal or median basisphenoid crest produced nearly or quite to basisphenoid bone (Fig. 8); auditory bulla inflated, completely rounded by fusion of tympanic processes of alisphenoid and petrous bones with an "entotympanic" bone between; ectotympanic bone hidden within bulla (Figs. 7, 26); mastoid bone inflated, the mastoidal process incorporated; mandibular symphysis rounded, not extended back beyond level of last incisor or canine (Fig. 5); inferior border of mandible slightly convex, lunate notch deep, angular process short, not produced beyond vertical plane of condylar process; articular condyle horizontal to vertical plane of mandibular ramus.

Auditory Bulla (Fig. 7)-A special function, if any, of the extremely large, inflated auditory bullae of microbiotheres has not been an object of inquiry. Large bullae are usually correlated with an arid habitat, which is not the case here. The small, furred, foldable ears of Dromiciops (Fig. 13), however, are usually associated with cold climates.

Seen historically, the bulla may have been bipartite (cf. Hershkovitz, 1992b, p. 21) as in most didelphoids no later than Early Cretaceous. For whatever reason, the bullar bones of the microbiotherium line began to inflate, leaving a wider than usual gap between the alisphenoid and petrous components. At this point, or earlier, a new adventitious bone, the so-called "entotympanic," appeared to fill the gap and close the middle ear on ventral and medial sides; at the same time the ectotympanic bone was drawn inside, leaving the porus as the only external opening. The evolutionary process was completed not later than Santacrucian (Miocene), as evidenced by the nearly complete but crushed auditory bulla described by Sinclair (1906, p. 405, pl. 62) and Segall (1969) under the referred specific name Microbiotherium tehuelchum Ameghino. Segall (1969, p. 494) noted the auditory region as "remarkably similar to that of Dromiciops." I compared both organs and found them indistinguishable. The Segall "tehuelchum" specimen is a Sinclair find (Fig. 7), not one of the original Ameghino specimens described under that name.

Differences between the malleus of Dromiciops and that of other marsupials were regarded by Segall $(1969$, p. 500$)$ as "fundamental. The neck is short and the manubrium is directed ventrad and only slightly craniad much less than in other marsupials. The medially open angle between head and neck is found in Dromiciops only." The significance of the differences noted remains to be established.

Postcranial Skeleton Measurements, ProPORTIONS-The appendicular skeleton (Table 3), with 7 cervical, 13 thoracic, 6 lumbar, and 2 sacral vertebrae, is the common, if not primitive, formula for therians generally. The dorsal vertebrae (thoracic plus lumbar) in American marsupials 


\begin{tabular}{|c|c|c|c|c|c|}
\hline Femur & $\frac{\text { Tibia }}{\text { Femur }}$ & $\frac{\text { Radius }+ \text { humerus }}{\text { Tibia }+ \text { femur }}$ & Trunk & $\frac{\text { Radius +humerus }}{\text { Trunk }}$ & $\frac{\text { Tibia }+ \text { femur }}{\text { Trunk }}$ \\
\hline 14. 14,18 & $160,147,122$ & $76,79,87$ & $52,48,63$ & $53,55.55$ & $70,69.63$ \\
\hline 19 & 133 & 80 & 67 & 54 & 67 \\
\hline 16 & 146 & 77 & 56 & 53 & 69 \\
\hline 18 & 122 & 77 & 50 & 62 & 80 \\
\hline $17.7(16.8-19.0) 15$ & $122.3(105-137) 15$ & $77.1(73-83) 15$ & $50.4(45-56) 15$ & $60.7(53-66) 15$ & $78.4(69-86) 15$ \\
\hline
\end{tabular}

may number up to 22 , and the sacral to 3 but generally regarded as stable with 2 .

The vertebral count in Dromiciops (sample number in parentheses) is cervical 7 (15); thoracic 13 (13), 14 (2); lumbar 5 (13), 6 (8); sacral 2 (15); caudal 28 (3), 29 (7), 30 (4), 32 (4); transitional 4 or 5 (13), 6 . The count of transitional vertebrae is usually included with the caudal. However, the transitionals differ sharply from sacral and caudal vertebrae (Fig. 27) but the last transitional and first caudal may not differ in some cases.

Postcranial skeletal parts of Dromiciops and marmosids are remarkably similar in number, form, and proportion of parts. In these respects, Dromiciops gliroides and marmosines of the genus Gracilinamus are indistinguishable (Table 3). The thoracolumbar flexure (Fig. 28), characteristic of most small mammals, is present.

TARSAL BONES-The astragalus and calcaneus (Fig. 15) each have 2 articular facets. The facets may be either separate or continuous with each other. Viewed by Szalay (1982a,b), the facets of the tarsal bones of Dromiciops are continuous, and, in his belief, all those of Australian marsupials are likewise continuous. In sharp contrast, he regarded the articular facets of tarsal bones of all other New World marsupials as separate. The presumed differences in tarsal anatomy between the few specimens of American and Australian marsupials provided Szalay with a presumptive basis for the phylogenetic separation of the two groups into Cohort Ameridelphia and Cohort Australidelphia, with the American Dromiciops enshrined as morphotype of the latter.

Upon examination of material at hand, I found the articular surfaces of the tarsal bones of Dromiciops to be continuous in 5 astragali and 4 calcanei and intermediate between both patterns in 2 calcanei. As for alleged American and Australian differences, it was shown (Hershkovitz, 1992a) that both articular patterns occur and vary about the same in marsupials of both continents.

LOCOMOTION-Cinematography was used by Pridmore (1994, p. 42) for recording locomotion in 2 adult male Dromiciops gliroides, both now preserved in FMNH. The animals were paced on 5 horizontal dowels varying in diameter from 6.3 to $39 \mathrm{~mm}$, and on a horizontal board $89 \mathrm{~mm}$ wide. Recorded were locomotor velocity, stride length, and gait. Neither of the first two categories was affected by the substrate, but gait was. Revealed was that two of the symmetrical gaits used by Dromiciops gliroides were similar to those of arboreal didelphids, phalangeroids, and most primates but were rarely used by other mammals. These gaits appeared to the author as "especially suited to locomotion on narrow branches, suggesting that this species may utilise such substrata to a significant extent in nature," which Dromiciops does within the bamboo thickets of its habitat. Pridmore conjectured "that the symmetrical gaits common to Dromiciops and arboreal didelphids and phalangeroids were present in ancestral marsupials...."

Dentition (Fig. 29, Table 4)-Formula:

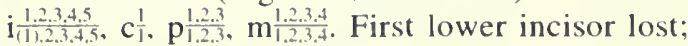
molar crowns euthemorphic, tritubercular, metacone of $\mathrm{m}^{12}$ always larger than paracone. Eruption sequence essentially as in didelphoids. with functional dp3 displaced by p3. 

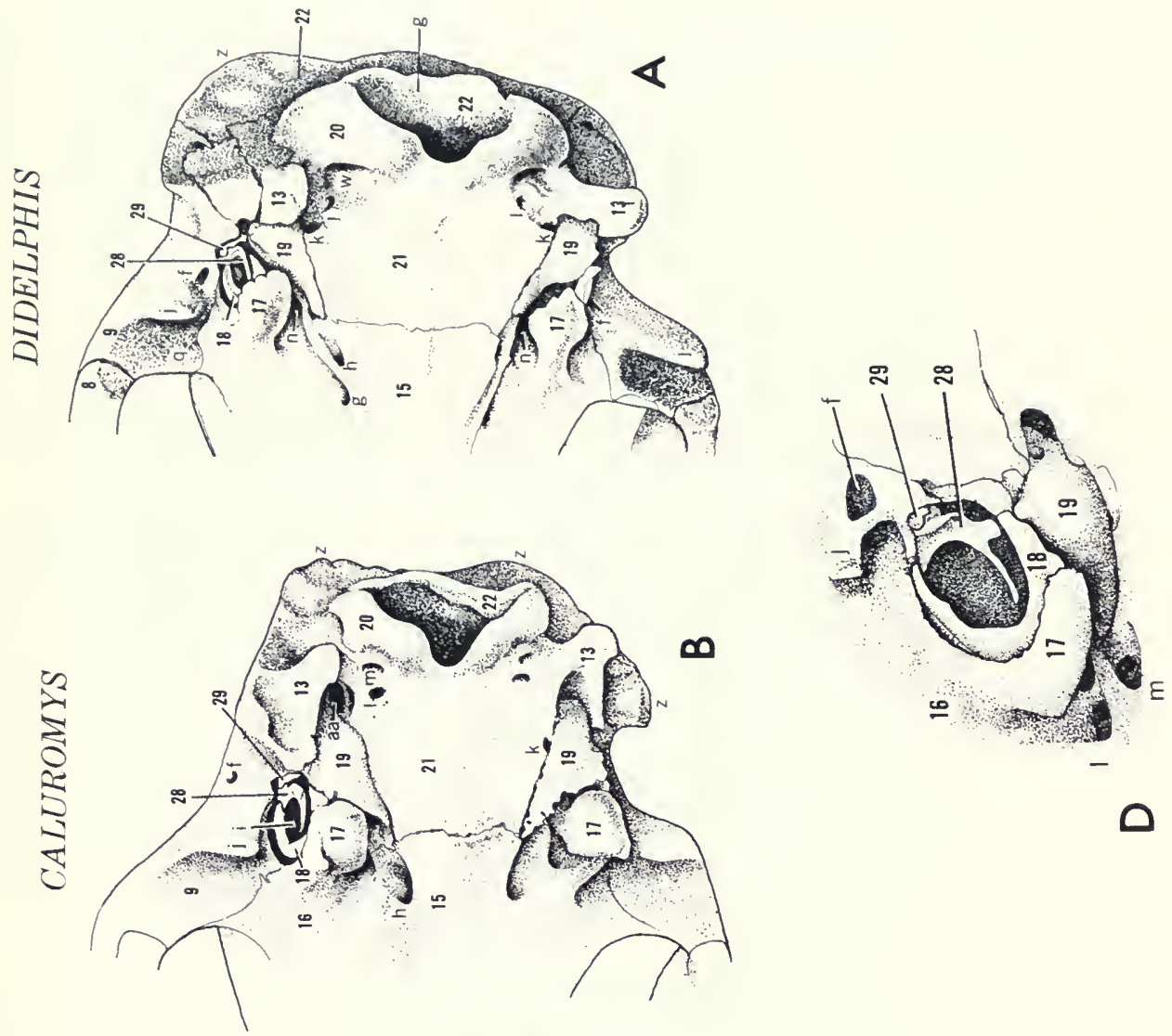

苍令 m. Ð

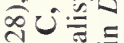

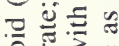
品 3

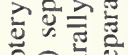

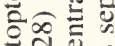

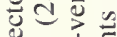

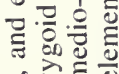
大ิ초워 응 可 品 तิ을 

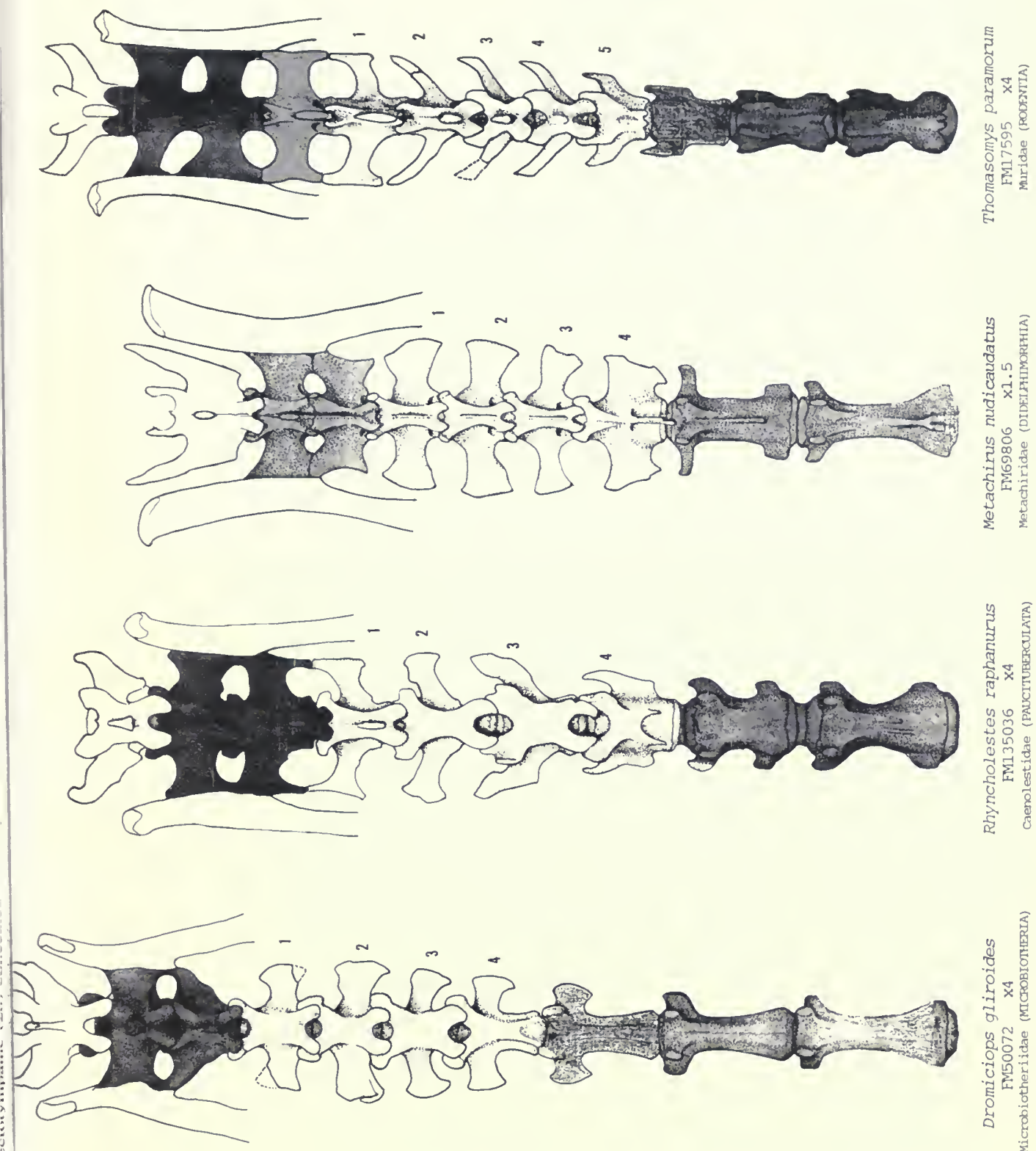


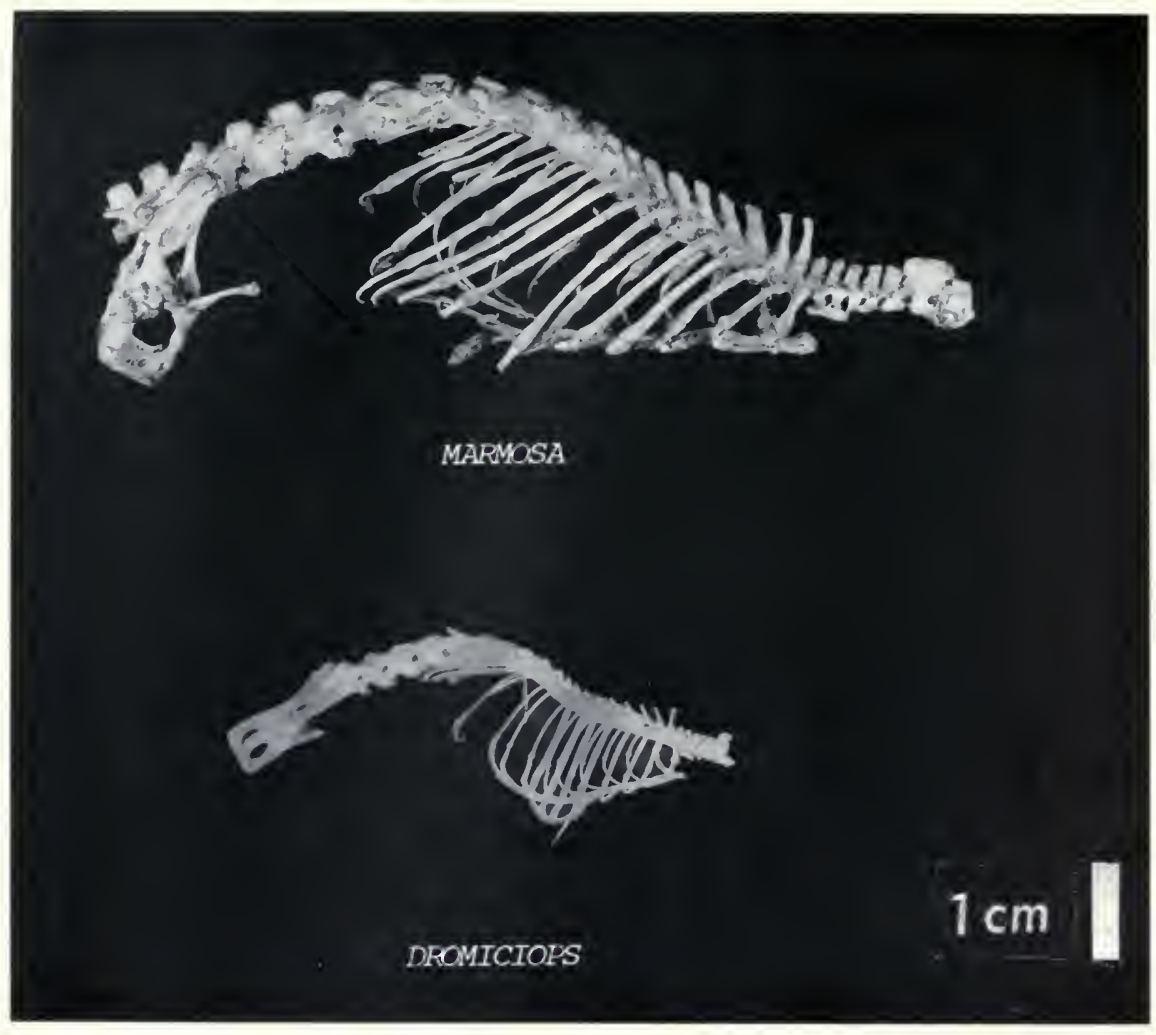

FIG. 28. Thoracolumbar flexure in Dromiciops gliroides (FMNH 127460) and a large Marmosa (FMNH 124611). The spinal curvature is normal in marsupials, rodents, and other "hunching" or "curling up" mammals, particularly when torpid.

Incisors simple, spatulate, diastema between the 2 first upper incisors about equal to width of either tooth, first upper incisor about one-third again higher than $\mathrm{i}^{2}$, the remaining incisors sequentially smaller, $i^{5}$ about half the size of $i^{1}$. All lower incisors about same size, none crowded but crowns touching or slightly overlapping, none staggered.

Canines stout, little curved, upper conical seen from inner side, nearly twice as high as first incisor and first premolar, diastema about as wide as height of $i^{5}$ or slightly wider; lower canine low, incisiform, touching $i_{5}$.

First upper premolar low with buccal cingulum, mesostyle and distostyle (heel) present, the worn tooth followed by diastema; $p^{2}$ about twice bulk of $\mathrm{p}^{1}$, fully erupted $\mathrm{p}^{3}$ about one-third again larger (taller) than $\mathrm{p}^{2}$; size of first lower premolar and $\mathrm{p}_{2}$ about equal, shorter than canine, cingula well defined, distostyles well developed; $p_{3}$ larger than $p_{2}$ with proportionately longer distostyle.

Third upper deciduous premolar about half bulk or less of displacing premolar, its paracone, metacone, and protocone well defined, cingula and terminal styles present; third lower deciduous premolar greatly reduced but trigonid and talonid well defined, the latter shorter than the former but slightly wider.

First molar, with all primary cusps, buccal shelf with mesostyle A, ectostyle B (= stylocone), ectostyle C, ectostyle D and terminal style $\mathrm{E} ; \mathrm{m}^{2}$ like

FIG. 29. Upper dental arcade of (A) Droniciops gliroides (Microbiotheriidae), (B) Philander opossum (Didelphidae), (C) Caenolestes fuliginosus (Caenolestidae), and (D) Caenolestes fuliginosus (occlusal aspect); $\mathrm{m}^{1-2} \mathrm{quad}-$ ritubercular, with hypocone (5); $\mathrm{m}^{3-4}$ tritubercular. Mandibular dental arcade of (E) Dromiciops gliroides (Microbiotheriidae), (F) Plilander opossum (Didelphidae), and (G) Caenolestes fuliginosus (Caenolestidae). For names of dental elements see page 48. 
A DROMICIOPS

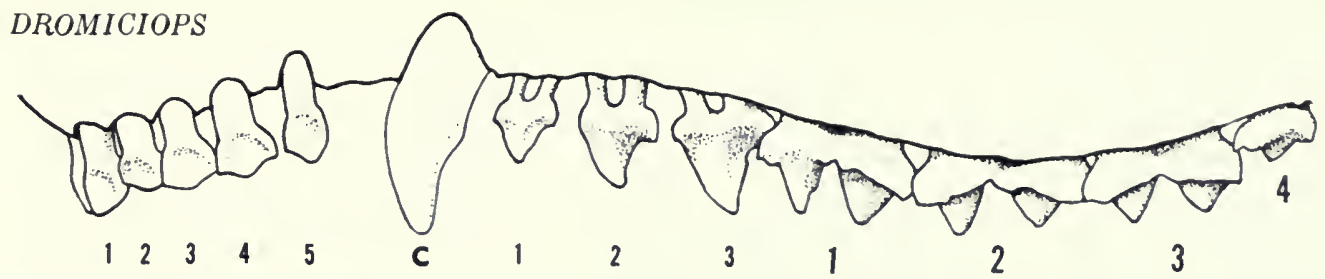

B PHILANDER

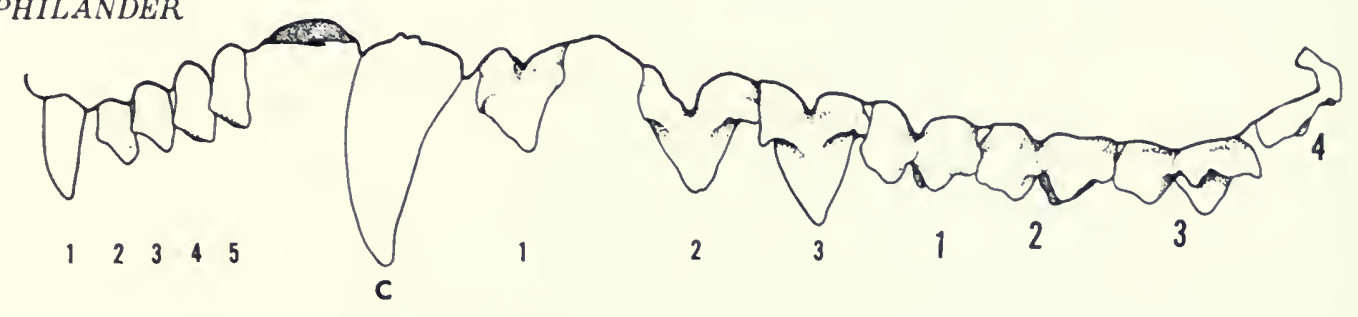

C CAENOLESTES

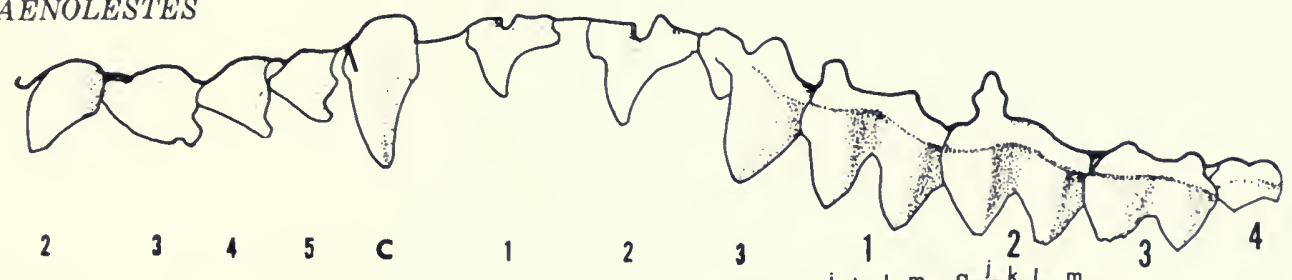

D CAENOLESTES

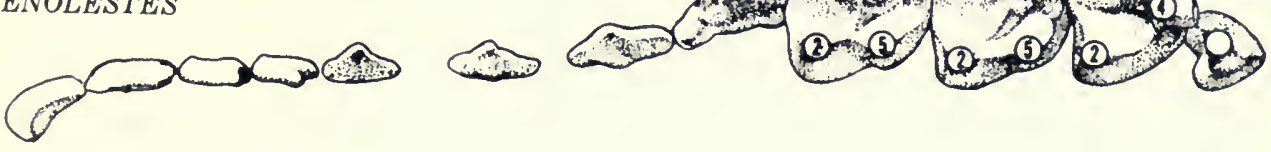

E DROMICIOPS

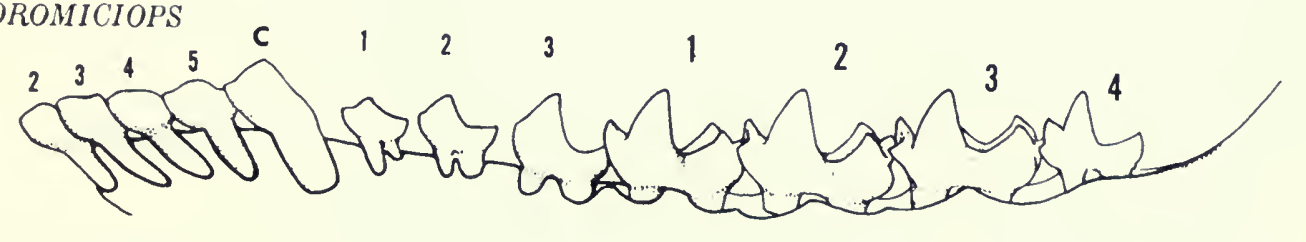

$\mathrm{F}_{\text {PHILANDER } \mathrm{c}}$

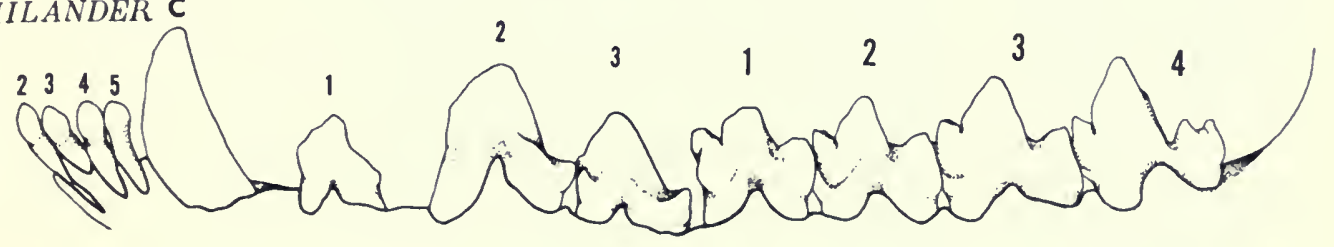

G

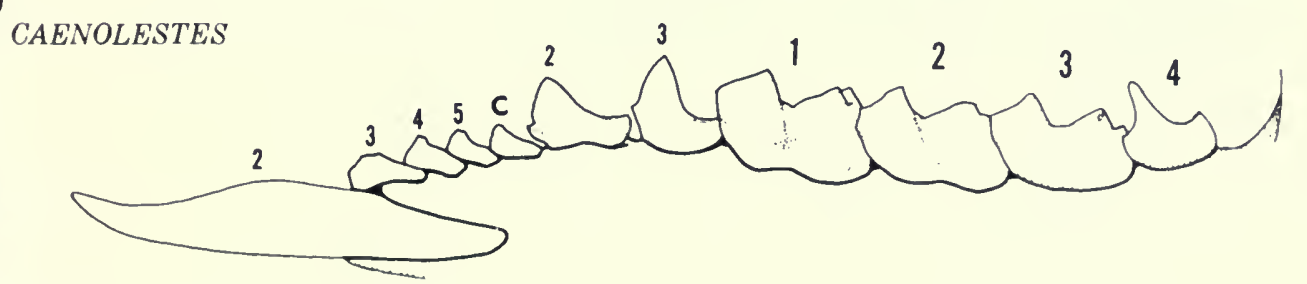


TABLE 4. Explanation of symbols used for elements of marsupial teeth adapted from quadritubercular molars. For names and locations of all dental elements see Hershkovitz (1977, pp. 299-301); the same symbols are used for homologues in upper and lower elements of tritubercular and quadritubercular molars.

\section{Upper teeth}

Cones $^{1}$

1 eocone (paracone)

3 -

4 metacone

5 hypocone present in 1 st and 2 nd

upper molars of Caenolestidae

Conules and styles ${ }^{2}$

A mesiostyle- $a$ (parastyle)

$E$ distostyle- $b$ (metastyle; hypoconule)

$d$ metaconule (hypertrophied to cusp proportions) rare

$B$ ectostyle- $j$ (stylocone) ectostyle- $k$

$C$ ectostyle-l (mesostyle; stylar cusp C of authors)

$D$ ectostyle-m

\section{Cristae $^{3}$}

(Cristae extend from/to or between cusps shown in brackets; reference cusps in parentheses are not necessarily elements of the indicated crista; primes (') have mostly been deleted in this study)

$I$ eocrista $[(A)-(B)-C-(E)]$

$I^{\prime}$ paracrista $[i-(A)]$ or alternate routes or portions $\quad I^{\prime} x[I-(B)-(l)]$

$I^{\prime \prime}$ postmetacrista [ $1-(b)$ in absence of 4 or 4-(E)]

$I^{\prime \prime \prime}$ centrocrista [1-4]

II epicrista [1-(2)] may be incomplete

III protoloph (protocrista) [2 crested portion of cingulum $B$ ]

$I V$ plagiocrista (metaloph) [2-d-(4)]

Basins or fossae

pretrigon basin or fossa

trigon basin or fossa

talon basin or fossa

pretalon basin or fossa

intercingular basin $\mathrm{A}$
2 protocone

post-talon basin or fossa

\section{Lower teeth}

Conids $^{1}$

1 eoconid (protoconid)

2 metaconid

3 paraconid

4 hypoconid

Conulids and stylids ${ }^{2}$

$A$ mesiostylid- $a$ (parastylid)

$E$ distostylid-b (hypoconulid)

\section{Cristids $^{3}$}

(Cristids extend from/to or between cuspids shown in brackets; reference cuspids in parentheses are not necessarily elements of the indicated cristid; primes (') have been mostly deleted in this study)

$I$ eocristid $[(A)-3-I-4-(E)]$

$I^{\prime \prime}$ postmetacristid [4- $\left.(E)\right]$

$I^{\prime \prime \prime}$ centrocristid [ $\left.1-4\right]$

II epicristid [1-(2)] may be incomplete

III protolophid (protocristid) [2(3) or 2 crested portion of cingulid $B$ ]

$I V$ plagiocristid [incomplete or absent]

Basins or fossids

"trigonid" basin or fossids anterior talonid basin or fossid posterior talonid basin or fossid

post-talonid basin or fossid

\section{Upper and lower teeth}

Cingula and cingulids

Main enamel folds $e x$ ectoflexus (between $I$ and 4 )
$A$ buccal or external (buccal shelf)
$B$ anterolingual or anterior (primary lingual shelf)
$C$ posterolingual cingulum

'Most cones (conids) are numbered in the order of their origin and development.

${ }^{2}$ Most conules (conulids) and styles (stylids) are listed in the order of their position from buccal to lingual and anterior to posterior. Rare or infrequent elements of the Dromiciops trigon such as conule $d$ are included. Supernumeraries or gemini of established cusps (cuspids) are not identified individually.

${ }^{3}$ Most cristae (cristids) are numbered in the order of their appearance or development in phylogeny, others are numbered opportunistically; all cristae (cristids), except $l-I^{\prime \prime \prime}$ inclusive, are modified parts of cingula (cingulids): homologies of the talonid cristids are not certain in every case. 
$\mathrm{m}^{1}$ or slightly larger; $\mathrm{m}^{3}$ like $\mathrm{m}^{2} ; \mathrm{m}^{4}$ greatly reduced, simplified, its metacone reduced or absent, stylar shelf and cusps reduced or absent; $m_{1} 3$ or 4 times larger than $\mathrm{dp}_{3}$, talonid larger than trigonid; $\mathrm{m}_{2}$ one-third or more larger than $\mathrm{m}_{1} ; \mathrm{m}_{3}$ about same size; $\mathrm{m}_{4}$ about two-thirds bulk $\mathrm{m}_{3}$, talonid greatly reduced but evidently functional, in marked contrast to nearly obsolete talon of $\mathrm{m}^{4}$.

DiPHYODONTY (Figs. 30-32)-Functional diphyodonty in marsupials is limited to the 3rd premolar field. The old, worn, fully molarized but minute dp3, fitted to the small jaw of juvenals, is loosened by its growing alveolus and displaced by the much larger erupting 3rd premolar. Shown (Figs. 30-32) is the deciduous tritubercular dp3 of Dromiciops in place or being displaced by the single-cusped third premolar. In eutherians the first functional teeth are the incisors $\left(\frac{3}{3}\right)$ and premolars $\left(\frac{1}{4}\right)$, all replaced by the second set. Molars $\left(\frac{3}{3}\right)$ are deciduous, erupt last, and are not replaced.

Sequence of Dental Eruption (Table 5)-All incisors and canines and the first 2 (of 3 ) premolars are fully erupted in 29 of the 38 available skulls. One or more teeth are unerupted or partially erupted in the remaining 9 skulls.

In two specimens of British Museum Dromiciops, Tribe (1990, p. 568) found $\mathrm{p}^{3}$ erupted before $\mathrm{m}^{4}$. In the Dromiciops at hand (Table 5), eruption of the 3 rd upper premolar precedes that of the upper 4 th molar in 4 specimens, follows in 1 , and erupts simultaneously in 2 . The lower 3 rd premolar erupts after $\mathrm{m}_{4}$ in 5 specimens, precedes in 1 , and appears at about the same time in 3.

One or more of the 4 lower incisors of Dromiciops may overlap slightly but none are staggered as in didelphoids. First and last functional molars are particularly variable.

PSEldoquadritubercularity (Fig. 32)—Left $\mathrm{m}^{3}$ (FMNH 134624) not completely erupted, appears to be quadritubercular. The " 4 th" cusp, however, is not a hypocone (5). It is a hypertrophied metaconule (conulid $d$ ), an element of crista IV that extends from protocone (cusp 2) to metacone (cusp 4). The metaconule is normally absent in Dromiciops and most didelphoids. The true hypocone (cusp 5) rises from cingulum $\mathrm{C}$ or the posterolingual shelf of the quadritubercular molar. It is absent in American marsupials except in the first 2 upper quadritubercular molars $\left(\mathrm{m}^{1.2}\right)$ of caenolestids.

KARYOTYPE (Fig. 33)-The chromosome complement of Dromiciops gliroides is the primitive $2 n=14$ (Spotorno and Fernández, 1971). The karyotypic formula is shared with slight individ- ual or specific modifications by members of most marsupial families (Reig et al., 1972).

Sharman (1973, p. 492, Fig. 4) declared that "Dromiciops alone has twenty-two autosomal arms all but one pair of its autosomes being metacentric or submetacentric." The authority and source of figure given are Reig et al. (1972). whose depicted karyotype of female Dromiciops, as well as Sharman's copy, shows the expected 24 autosomal arms. Later, Sharman (1982) gave a reconstructed account of the female Dromiciops karyotype, relating it to Australian types with 14 chromosomes. In this the investigator evidently conformed to the dubious Szalay (1982a,b) concept of the American and Australian marsupial dichotomy based on unrealistic tarsal bone patterns.

Sex chromosome mosaicism in Dromiciops somatic tissue from Valdivia and Concepción. Chile, was reported by Gallardo and Patterson (1987, p. 113 ) in bone marrow cells of 5 adult males with 13 chromosomes, the $\mathrm{Y}$ being the chromosome believed absent. The complement of 2 females consisted of the normal 14 . The investigators were aware that a small chromosome like the $\mathrm{Y}$ might be overlooked. The "universal absence in all counted plates [291 from males] makes this alternative highly unlikely. Available data favor a somatic elimination of the $\mathrm{Y}$ chromosome." The normal complement of 14 in spermatocytes has been reported by Fernández et al. (1979).

BRown AND White Adipose Tissue-Absence of brown adipose tissue (BAT) or brown fat in Dromiciops was reported by Hayward and Lisson (1992). The examination of representatives of all families of Australian marsupials, the 2 families of monotremes, and 3 orders of American marsupials also showed absence of BAT. At the same time, the authors confirmed the presence of BAT in all eutherians and disproved its occurrence in other vertebrates believed to store brown fat.

The phylogenetic significance of brown fat as a unique character of eutherians rates with the pattern of the eutherian reproductive system as evidence of the independent origins of Eutheria and Metatheria.

TORPOR AND HIBERNATION-Dromiciops becomes torpid for the 2 coldest months of the year. Santos (1946) noted that during that period they are often found in hollows of old or dry trees where firewood gatherers come upon them. Live animals Greer (1965, p. 105) captured in Malleco during winter assumed a flexed position in the cold of night. When early morning temperatures dropped to $4.5^{\circ} \mathrm{C}$ or lower, bodies of the animals 

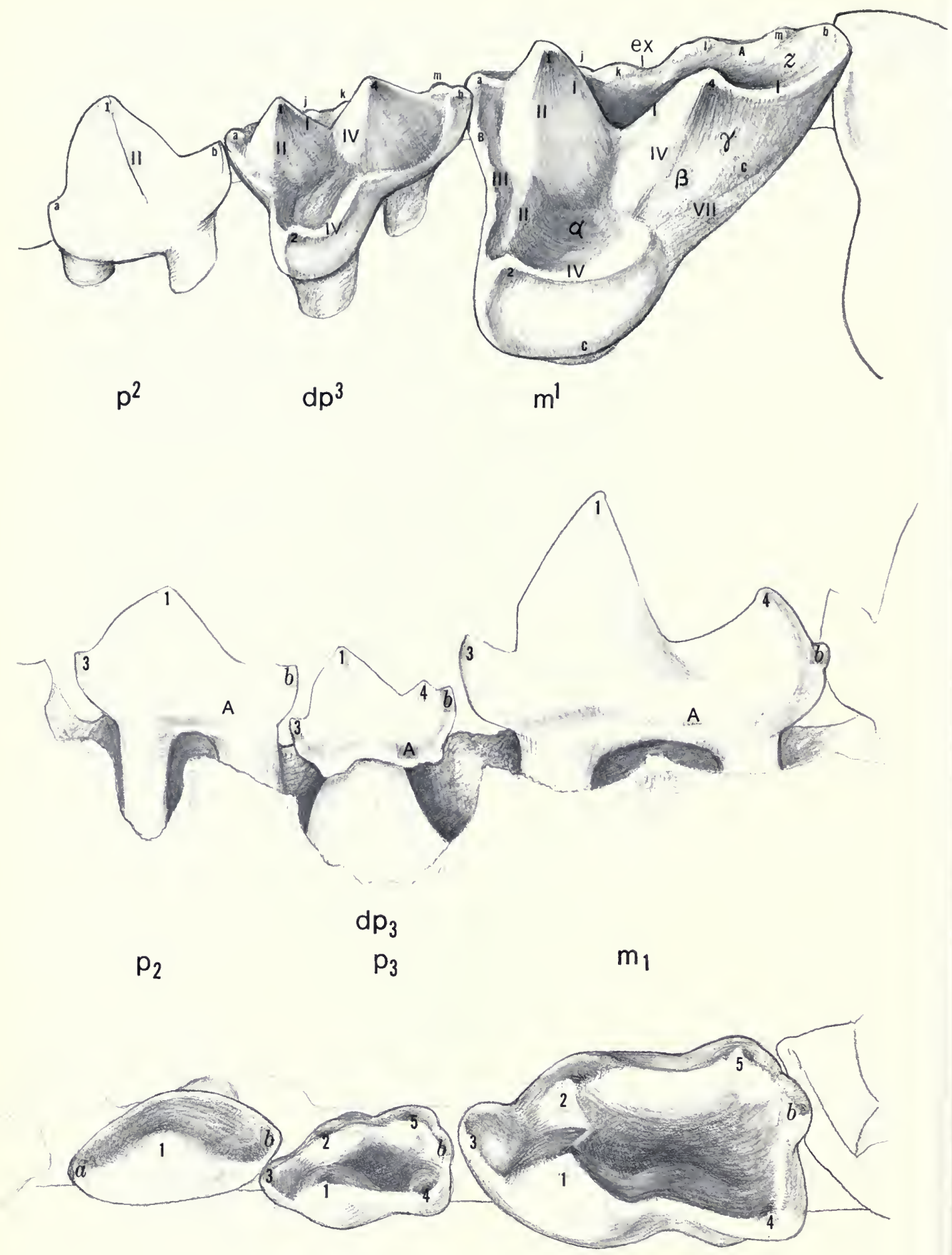

$\begin{array}{lll}p_{2} & p_{3} & m_{1}\end{array}$ 


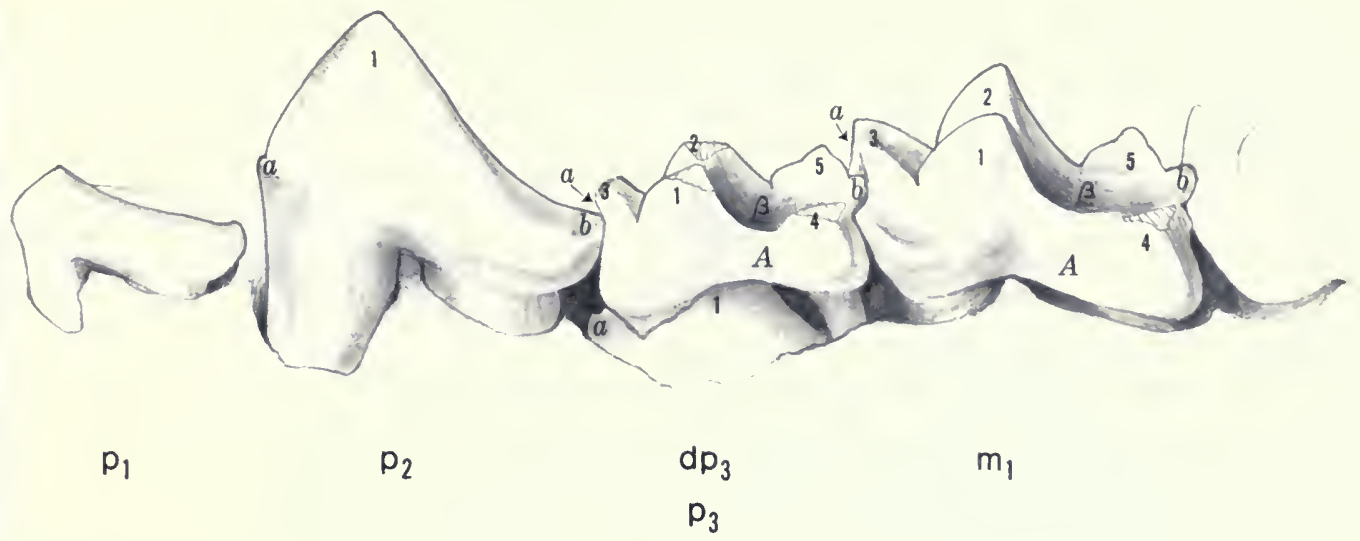

FIG. 31. Philander opossum (juvenal). Right lower cheek teeth shown are first 2 premolars erupted, third premolar $\left(\mathrm{p}_{3}\right)$ erupting and displacing deciduous $\mathrm{d}_{\mathrm{p}_{3}}$, and first molar $\left(\mathrm{m}_{1}\right)$; compare morphology of $\mathrm{d}_{3}$ with $\mathrm{p}_{2}$ and $\mathrm{m}_{1}$. For names of dental elements see page 48 .

became stiff and cold to the touch. One, after being warmed in Greer's shirt pocket, revived, crawled out of the pocket, and resumed activity as usual.

A male and four females were observed during periods of torpor by Grant and Temple-Smith (1987, p. 273):

All individuals were curled on their sides with the tail passed over the head and fore feet and nose applied closely to the curled ventral side of the body. The rear feet were often exposed and trembled during arousal. At some time during arousal all animals shifted their positions from this lying, curled posture to a sitting position. In all instances of torpor the eyes were closed and the ears folded down until $T$, [body surface temperature] was close to that of an active animal....

Torpidity lasted over 36 hours in two animals. Apnea during torpidity was observed lasting 2 to 30 minutes, followed by several deep breaths or a series of up to 30 rapid respirations. Respiration rates during arousal increased from less than 100 RPM to over 200 RPM. Weight of the animals ranged from about 18 to $30 \mathrm{~g}$; body surface temperature of the active animal ranged from $28^{\circ}$ to $34^{\circ} \mathrm{C}$

O. P. Pearson (1983, p. 483), who trapped
Dromiciops in Patagonia, Argentina, found it torpid in the traps during winter. He caught two on 18 April "when patches of snow lay in the forest, and the overnight temperature was $0^{\circ} \mathrm{C}$... A captive that we awakened abruptly during the day on two occasions had a deep rectal temperature of only $33^{\circ}$ and $33.5^{\circ} \mathrm{C}$, but nevertheless was alert and capable of quick and agile movements." Oliver Schneider (1946) described the animal entering torpor as lying down on one side, doubling up, and turning cold and stiff. The animal is by nature, Oliver Schneider declared, "timid, unsociable and treacherous [!]." It is normally nocturnal.

The heartbeat before torpor, determined by Mann (1978), is 230 per minute, and drops to less than 30 per minute when the animal is chilled to torpor. The shallow, daily bouts of torpor, which may last minutes to less than 20 hours, characterize all but one of the cases of torpor described above, including those for which time values were not available. The minimum body temperatures of the torpid examples of American marsupials should range from $16^{\circ}$ to $28^{\circ} \mathrm{C}$, according to Geiser (1994). The same authority described hibernation in marsupials as a deep, prolonged torpor.

FiG. 30. A, Dromiciops gliroides (juvenal): 3 upper left cheek teeth shown are, respectively, developing second remolar $\left(\mathrm{p}^{2}\right)$, fully functioning deciduous third premolar $\left(\mathrm{d} \mathrm{p}^{3}\right)$, and fully erupted first molar $\left(\mathrm{m}^{1}\right)$; compare morshology of $\mathrm{p}^{2}$ and $\mathrm{dp}^{3}$. B, Dromiciops gliroides (juvenal): 3 left lower cheek teeth shown are, respectively, premolar ? $\left(\mathrm{p}_{2}\right)$, premolar $3\left(\mathrm{p}_{3}\right)$ erupting and displacing $\mathrm{dp}_{3}$. and fully erupted lower molar $1\left(\mathrm{~m}_{1}\right)$; compare morphology of $\mathrm{Ip}_{3}$ and $\mathrm{p}_{2}$. C. Dromiciops gliroides (juvenal): ocelusal view of same lower teeth shown in $\mathbf{B}$; compare morphology of $d p_{3}$ and $p_{2}$. For names of dental elements see page 48 . 


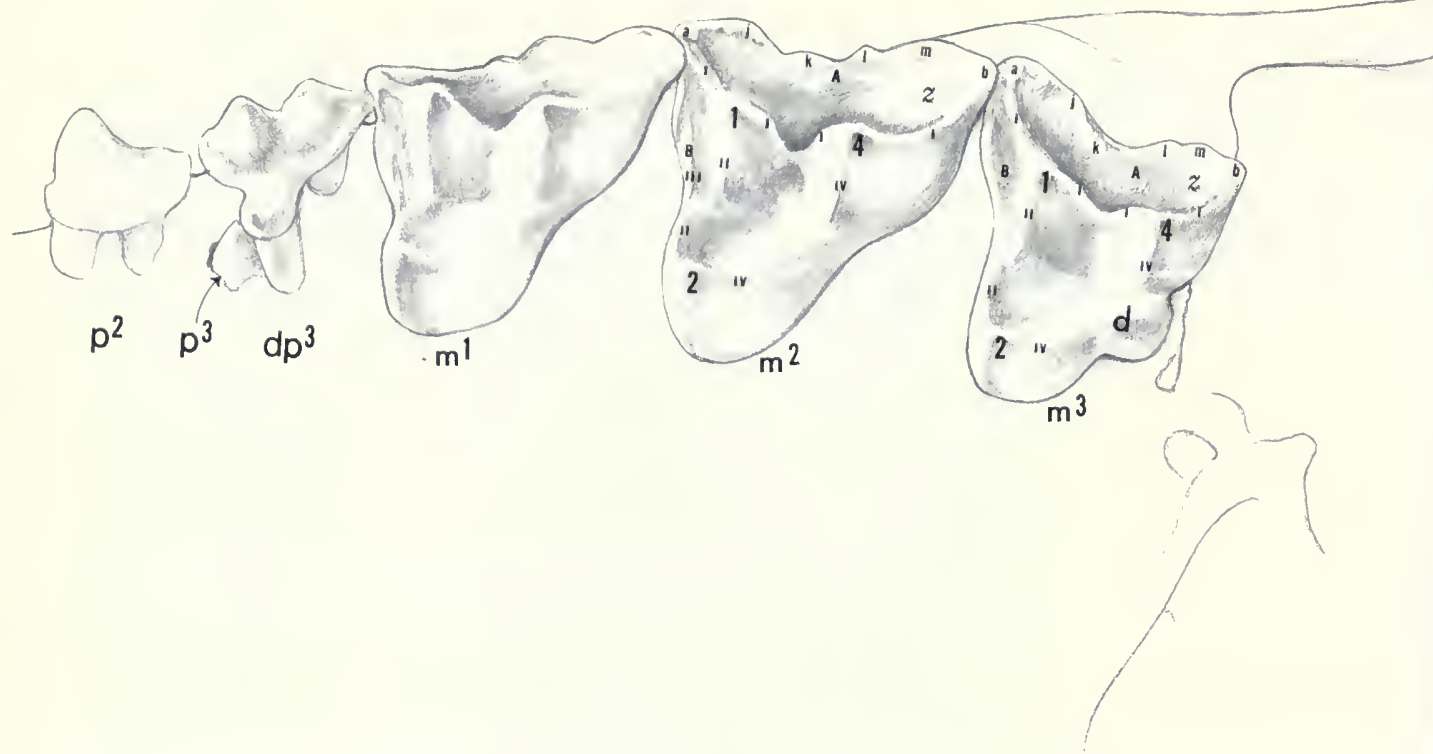

FIG. 32. Dromiciops gliroides $\mathrm{p}^{2}-\mathrm{m}^{3}$ (FMNH 134624) with "fourth" cusp, a hypertrophied metaconule (d) or "pseudohypocone." $\mathrm{p}^{2}$ fully erupted, $\mathrm{p}^{3}$ displacing functional deciduous third premolar $\mathrm{dp}^{3}$, followed by fully formed $\mathrm{m}^{1-3}$; diminutive last molar $\left(\mathrm{m}^{4}\right)$ unerupted or lost. For names of dental elements see page 48 .

TABLE 5. Sequence of dental eruption in Dromiciops: of 38 available skulls, 9 with 1 or more unerupted or partially erupted teeth are analyzed; remaining skulls not listed.

\begin{tabular}{|c|c|c|c|c|c|c|c|c|c|}
\hline \multirow[b]{3}{*}{ FMNH no. } & \multicolumn{3}{|c|}{ Premolars } & \multirow{3}{*}{$\begin{array}{c}\text { dp } \\
3 \\
3\end{array}$} & \multicolumn{4}{|c|}{ Molars } & \multirow[b]{3}{*}{ Remarks } \\
\hline & 1 & 2 & 3 & & 1 & 2 & 3 & 4 & \\
\hline & 1 & 2 & 3 & & 1 & 2 & 3 & 4 & \\
\hline \multirow[t]{2}{*}{127438} & $\mathrm{x}$ & $\mathrm{x}$ & $\mathrm{v}$ & ? & $\mathrm{v}$ & $\mathrm{v}$ & $\mathrm{v}$ & 0 & \\
\hline & $\mathrm{x}$ & $\mathrm{x}$ & $\mathrm{v}$ & - & $\mathrm{v}$ & $\mathrm{v}$ & $\mathrm{v}$ & $\mathrm{v}$ & \\
\hline \multirow[t]{2}{*}{134624} & $\mathrm{x}$ & $\mathrm{x}$ & 0 & $\mathrm{x}$ & $\mathrm{x}$ & $\mathrm{x}$ & $\mathrm{x}$ & $?$ & \\
\hline & $\mathrm{x}$ & $\mathrm{x}$ & 0 & $\mathrm{x}$ & $\mathrm{x}$ & $\mathrm{x}$ & $\mathrm{x}$ & $\mathrm{x}$ & \\
\hline \multirow[t]{2}{*}{127438} & $\mathrm{x}$ & $\mathrm{x}$ & $\mathrm{v}$ & - & $\mathrm{x}$ & $\mathrm{x}$ & $\mathrm{x}$ & 0 & \\
\hline & $\mathrm{x}$ & $\mathrm{x}$ & 0 & $\mathrm{x}$ & $\mathrm{x}$ & $\mathrm{x}$ & $\mathrm{x}$ & $\mathrm{x}$ & \\
\hline \multirow[t]{2}{*}{127445} & $\mathrm{x}$ & $\mathrm{x}$ & 0 & $\mathrm{x}$ & $\mathrm{x}$ & $\mathrm{x}$ & $\mathrm{x}$ & $v$ & \\
\hline & $\mathrm{x}$ & $\mathrm{x}$ & 0 & $\mathrm{x}$ & $\mathrm{x}$ & $\mathrm{x}$ & $\mathrm{x}$ & $\mathrm{x}$ & \\
\hline 127465 & $\mathrm{x}$ & $\mathrm{x}$ & 0 & $\mathrm{x}$ & $\mathrm{x}$ & $\mathrm{x}$ & $\mathrm{v}$ & 0 & Mandibles missing \\
\hline \multirow[t]{2}{*}{127457} & $\mathrm{x}$ & $\mathrm{x}$ & v & 0 & $\mathrm{x}$ & $\mathrm{x}$ & $\mathrm{x}$ & $\bigcirc$ & \\
\hline & $\mathrm{x}$ & $\mathrm{x}$ & $\mathrm{v}$ & [ ] & $\mathrm{x}$ & $\mathrm{x}$ & $\mathrm{x}$ & 0 & $\mathrm{dp}_{3}$ lost \\
\hline \multirow[t]{2}{*}{129806} & $\mathrm{x}$ & $\mathrm{x}$ & $\mathrm{v}$ & 0 & $\mathrm{x}$ & $\mathrm{x}$ & $\mathrm{x}$ & 0 & \\
\hline & $\mathrm{x}$ & $\mathrm{x}$ & v & 0 & $\mathrm{x}$ & $\mathrm{x}$ & $\mathrm{x}$ & $\mathrm{x}$ & \\
\hline \multirow[t]{2}{*}{127454} & $\mathrm{x}$ & $\mathrm{x}$ & $\mathrm{x}$ & 0 & $\mathrm{x}$ & $\mathrm{x}$ & $\mathrm{x}$ & $\mathrm{x}$ & \\
\hline & $\mathrm{x}$ & $\mathrm{x}$ & $\mathrm{v}$ & 0 & $\mathrm{x}$ & $\mathrm{x}$ & $\mathrm{x}$ & $\mathrm{x}$ & \\
\hline \multirow[t]{2}{*}{50043} & $\mathrm{x}$ & $\mathrm{x}$ & $\mathrm{x}$ & 0 & $\mathrm{x}$ & $x$ & $\mathrm{x}$ & [ ] & $\mathrm{m}^{4}$ lost \\
\hline & $\mathrm{x}$ & $\mathrm{x}$ & $\mathrm{x}$ & - & $\mathrm{x}$ & $\mathrm{x}$ & $\mathrm{x}$ & $\mathrm{x}$ & \\
\hline
\end{tabular}

Symbols for dental condition: $\mathrm{x}=$ fully erupted; $\mathrm{v}=$ partially erupted; $\mathrm{O}=$ unerupted; $\boldsymbol{O}=$ displaced; $[\mathrm{]}=$ lost 

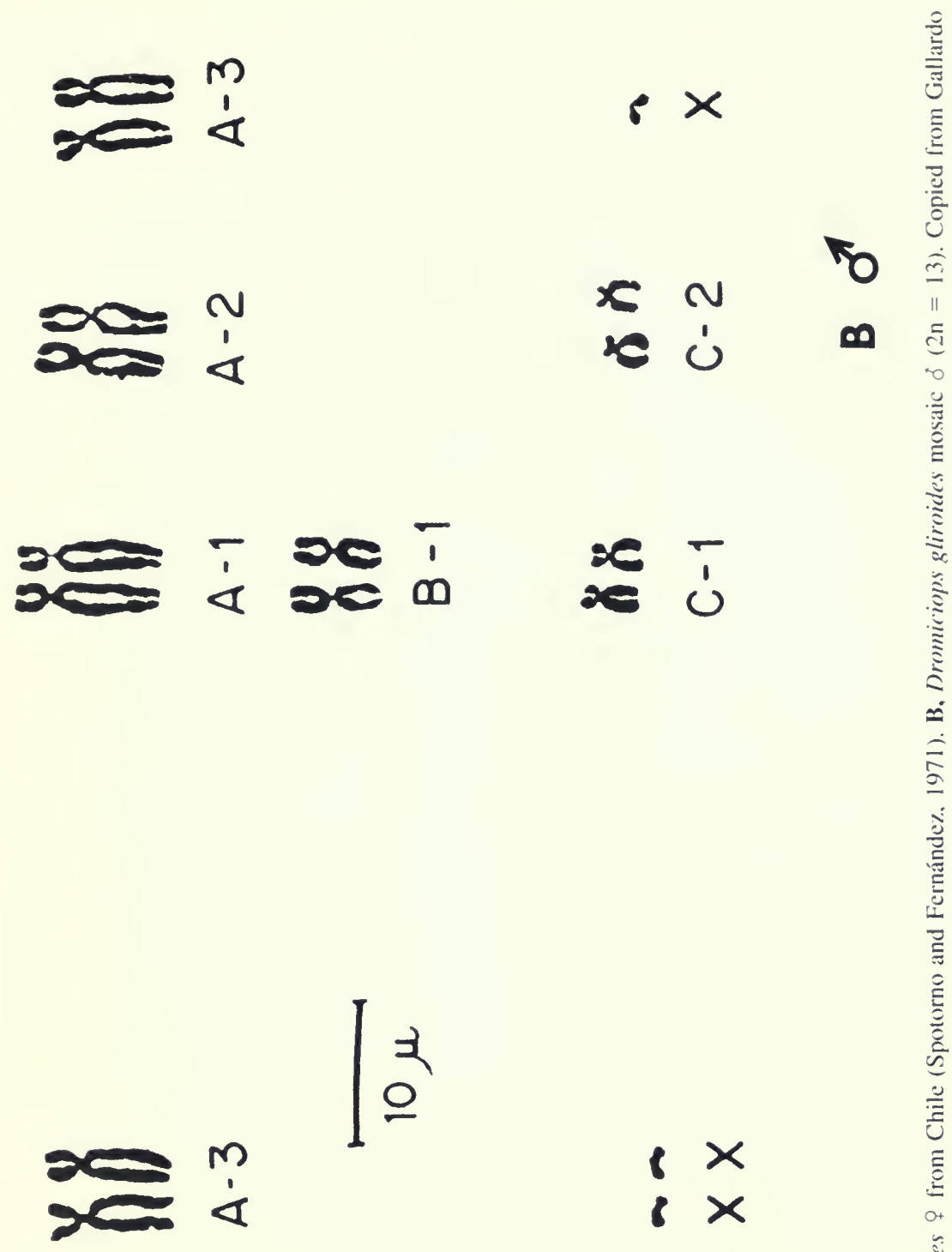

$1 x$
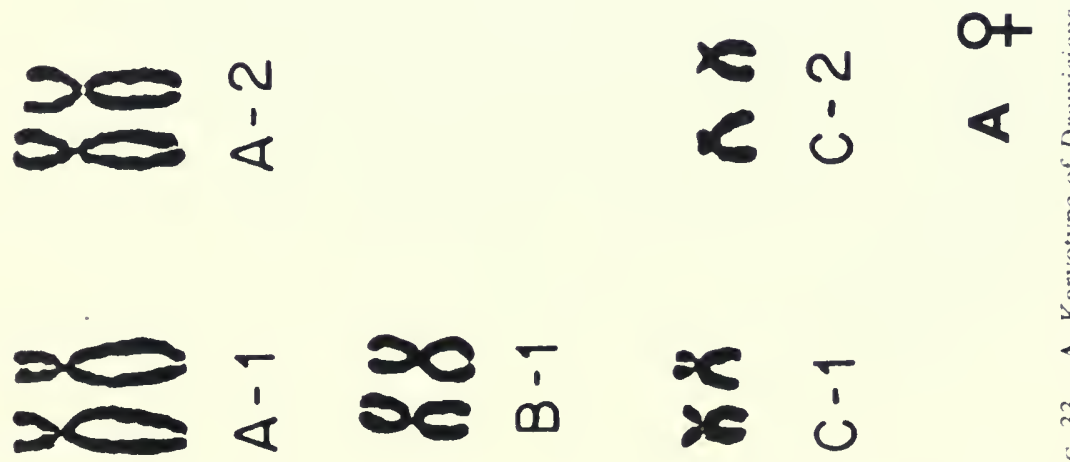
TABLE 6. Revised summary of nests and occupants of Dromiciops gliroides found and/or reported by Jiménez and Rageot (1979, Table 1, p. 84).

\begin{tabular}{|c|c|c|c|c|}
\hline Date & National park & Nests/occupants & Site & $\begin{array}{l}\text { Nest height } \\
\text { above ground }\end{array}$ \\
\hline $21 / 10 / 75$ & Tolhuaca & I nest with $q$ & Bamboo-laurel forest & \\
\hline$-/ 12 / 76$ & Nahuelbuta & Ad. $\delta, q$ captured & 一 & - \\
\hline 一 & Cerro Ñielol & 2 fresh nests & $\begin{array}{l}1 \text { in nest of thrush on } \\
\text { branches of olivillo }\end{array}$ & $3 \mathrm{~m}$ high \\
\hline$-13 / 77$ & Conguillío & 9 nests ( 6 fresh) & $\begin{array}{l}1 \text { in Araucaria tree, } 1 \text { in } \\
\text { myrtle tree, } 7 \text { in bam- } \\
\text { boo }\end{array}$ & $\begin{array}{l}\text { Average height } 1.2 \\
\mathrm{~m}\end{array}$ \\
\hline$-/ 9 / 77$ & Cerro Ñielol & 1 nest with torpid $\delta$ & $\begin{array}{l}\text { In copihue }{ }^{1} \text { on olivillo } \\
\text { tree }\end{array}$ & $2 \mathrm{~m}$ high \\
\hline$-/ 11 / 77$ & Conguillío & 7 nests & Most fresh, in dead trunks & \\
\hline $2 / 2 / 78$ & Cerro Ñielol & $\begin{array}{l}\text { Nest with } q \text { and } 4 \\
\text { young }\end{array}$ & In copihue & $1.5 \mathrm{~m}$ high \\
\hline $3 / 2 / 78$ & Villarrica & $\begin{array}{l}\text { Nest with } q \text { and } 4 \\
\text { young }\end{array}$ & In bamboo zone & $1.2 \mathrm{~m} \mathrm{high}$ \\
\hline
\end{tabular}

${ }^{1}$ Lapageria rosea.

with bouts lasting from 1 to 3 weeks. The minimum body temperature, ranging from $1^{\circ}$ to $6^{\circ} \mathrm{C}$, in Australian marsupials is unknown in American species. The male and four females of Dromiciops observed during periods of torpor by Grant and Temple-Smith (1987) (see above) were not true hibernators.

Oxygen consumption by a $50-\mathrm{g}$ male Dromiciops gliroides studied while torpid by Rosenmann and Ampuero (1981) was less than 0.1 of normal values for a period of 5 consecutive days. Respiration by the subject was slow and irregular, with periods of 8 to $23 \mathrm{~min}$ of apnea followed by short respiratory periods of 45 to $75 \mathrm{sec}$ with the rate falling from 370 to 2 per min. The length and depth of torpidity and the respiratory periodicity in this case are signs of true hibernation.

FAT StORAGE-Dromiciops stores fat in the base of its tail and under the skin, particularly in the interscapular region, during the bountiful summer and metabolizes the fat during the barren winter. There is no record of torpor in Dromiciops having been induced by deprivation of food or water.

Vocalization-The Dromiciops call has been recorded by Oliver Schneider (1946, p. 68) as "tzchi tzchi-kod kod"; the sounds produced by a combination of utterances through teeth and throat. Greer (1965, p. 105), who captured the live animals, mentioned that "at night, or when left unmolested for a period of time, some individuals made soft buzzing noises."

BeHAVIOR (GENERAL) - An aquaintance of Frederico Philippi, who first described Didelphys aus- tralis (= Dromiciops gliroides Thomas), recounted an experience quoted by Philippi (1893b, p. 33) and freely translated here from Spanish. A freshly captured monito del monte was housed in a wire bird cage from which it easily escaped. The vacancy was filled with a bird too large to force its way out between the bars. A few days later, the starved and thirsty fugitive was found hiding behind a piece of furniture. It was returned to the cage with the bird. No sooner was the bird perceived than the marsupial leaped to its throat, chewed it into bits, sucked the blood, then devoured all but the feathers.

Jiménez and Rageot (1979, pp. 84-85) found a mother and four suckling young in a nest supported by intertwining bamboo in the National Park Cerro Nielol, February 1979 (Table 6). The female was active at the moment of capture and showed no sign of fear or aggression, nor did she attempt to escape. The young continued to suckle while being carried in the nest to the authors' laboratory. During the first 2 days of captivity the young crawled into the mother's mammary field despite the fact that their combined bulk was about half that of the mother. The young did not return to the field after the 2 nd day. During the 1 st week of captivity the female left the nest with the young clinging to her nipples. This did not recur from the 2 nd week onward. A young one that had been lost in a corner of the laboratory was not sought by its mother. Notwithstanding. the young succeeded in finding its nest in the cage.

In another instance, a field worker's approach 
to a nest in the wild caused the mother to flee, abandoning her 4 young, 2 males and 2 females (Table 6).

A female captured in the bamboo thicket proved to be one of the most gentle encountered. From the beginning she allowed her head to be stroked. Let out of the cage at night to roam freely, she always returned to her nest between 7 and $8: 30$ in the morning.

TRAPABILITY - Patterson et al. (1990, p. 630) noted a peculiarity of Dromiciops gliroides not exhibited by any of the other 9 small mammals they trapped at the same time. The "highly scansorial habits of this species," they affirmed, "are underscored by prehensile tail, opposable toes, and by their unqualified aversion to entering enclosed live traps; not one of 61 Dromiciops captured at La Picada was taken in a Sherman live trap."

DIET-Mother and young ate fruit without preference for any one kind. Meat, insects, or other proteins as part of the diet were not mentioned by the captors, Jiménez and Rageot (1979). An adult pair captured later rejected the proffered insect larvae and bananas but took apples, and bread with or without butter. Other captured Dromiciops accepted a variety of fruit. The tame and docile captive female that roamed the house never accepted insects. Her preferred foods were bananas, grapes, cherries, pears, honey, and marmalade. On occasion she ate a piece of cooked meat or fish. The small birds offered were first ignored but later eaten piecemeal.

A male held captive for nearly a year by $\mathrm{Ji}$ ménez and Rageot (1979) remained timid and never really tamed. His diet was $80 \%$ fruit, the remainder insects. A mouse placed in his cage elicited no attention. Raw or cooked meat, eggs, and honey failed to attract him. He did like pears, bananas, apples, tomatoes, cooked potatoes, rice, and milk dessert.

A captured female and her brood killed a young sparrow. She skinned the head first, then ate the brain. following with the remainder of the bird, the feathers excepted. Her young helped consume the bird.

The male found torpid in a bamboo nest (Table 6) by Jiménez and Rageot ate $80 \%$ fruit and $20 \%$ live insects. At one time he ate an earthworm placed in his cage. Another time, a lizard placed in the cage was killed and its entrails were eaten. On the other hand, a live mouse introduced into the cage lived congenially with the opossum.

Krieg (1925), who observed the species in Ar- gentina, recorded its diet as insects, larvae, nesting birds, and small mice. Mann (1955) confirmed that Dromiciops is carnivorous and insectivorous. Captives held by O. P. Pearson (1983) ate apples, grubs, flies, and small lizards, but not frogs. From all accounts, it appears that captive Dromiciops prefers anything off the dining table to food caught or picked outdoors.

Stomach contents of the Dromiciops captured by Meserve et al. (1988) in La Picada contained $71.8 \%$ invertebrates, of which $58.6 \%$ were mature arthropods. Annelids and invertebrates other than arthropods were not eaten, but some seeds and vegetative matter, including bryophytes, were consumed. Fungi, so much a dietary component for co-occurring Rhyncholestes, Geoxus, and Abrothrix, were hardly touched.

Greer (1965) returned to Michigan from Chile with a live Dromiciops that weighed $26.5 \mathrm{~g}$ on arrival. After an average daily consumption of 4.1 $\mathrm{g}$ ham and $6 \mathrm{cc}$ water, the weight of the animal increased $3 \mathrm{~g}$ in 5 days.

According to Mann (1978), the tongue is coated with a mucilagenous saliva that helps Dromiciops capture and hold slow-moving prey, a questionable interpretation.

Nests (Plate 2, Table 6)-Greer (1965) found nests in thickets of Chusquea bent to the ground by a fallen tree, but none in trees. He mentioned trapping an animal in front of a burrow, implying it might have been used by the monitos, but he saw no nest. Mann (1978) saw nests in moss and under rocks, fallen logs, and heaps of branches.

During his exploration of Volcán Osorno, Mann (1978, p. 35) discovered 5 Dromiciops nests in hollow trees, fallen trunks, and branches of bamboo (Chusquea) situated 1 or $2 \mathrm{~m}$ above ground. The nests were made of interlaced leaves of bamboo with openings on the side 4 or $5 \mathrm{~cm}$ wide. The entrances to 2 nests were each provided with a short hallway fashioned of bamboo leaves. Four of the nests were roofed with moss.

Jiménez and Rageot (1979) found nests in hollow trees or in tangled branches about 1 or $2 \mathrm{~m}$ above ground. The nests described by Jiménez and Rageot were round or ovoid, usually made of leaves of bamboo interwoven with the smallest leaves on the inside, or made with dry bamboo leaves only and concealed among the bamboo intertwinings. Found in some nests were ectoparasites, insect chitin, and eggshell. Nests seen by Pearson (1983) in Patagonia were also spherical, made of bamboo leaves, and located in shrubs or low trees. Most, perhaps all, other American mar- 
supials build nests, many of leaves, none, to my knowledge, of bamboo. All, like Dromiciops, avail themselves opportunistically of any suitable natural refuge, such as forest debris, tree hollows, depressions under logs, tunnels, and the like. Nothing is known of the nesting habits of canopyinhabiting opossums. Rodents nesting in bamboocovered tall trees, however, are known. The Rattus-sized echimyid Olallamys (= Thrinacodus) I captured in the Cordillera Oriental near Bogotá, Colombia, lived in Chusquea-shrouded trees, including tall pines, ate its fruit and shoots, and fabricated small ovoid nests with the leaves. The related Kannabateomys of southeastern Brazil, Paraguay and northern Argentina also lives in Chusquea-covered trees.

ENEMIES-Particular enemies or predators of Dromiciops have not been mentioned by any observer to my knowledge. Mann (1978, p. 29) suggested that ill-tasting secretions of dermal glands repel potential predators. More likely, the secretions are markers and sexual attractants. The Chilean environment harbors a few species of carnivores that must prey on small mammals, probably including Dromiciops, the marmosid Thylamys elegans, and small game. Pearson and Pearson (1982, p. 136) observed that the "dense bamboo provides an effective screen against raptors and that small carnivores such as skunks, weasels and wildcats are scarce or absent."

Specimens Examined (Skin, Skeletal, Dental, Entire)-Total 59. CHILE: Isla Chiloé (Cocauque, 1; locality not recorded, 1); Llanquihue (Peulla, 2; Río Colorado, 3; Río Negro, 5; Contao, Palana, 15); Malleco (La Auracania, 3; Sierra Nahuelbuta, 2; Victoria, 1); Osorno (Valle de la Picada, 35; Osorno, 3).

\section{Acknowledgments}

I am beholden to Kathy Kazol Telfer, Cameron Pfiffner, and Maggie Robertson for the illustrations, and to technical assistants Eunice Hoshizaki and Barbara Brown for their help in manuscript production. I am particularly grateful to my colleague Bruce Patterson for use of his photographs of bamboo, the female Dromiciops with exposed mammary field and nipples, and use of data from Patterson's and Milton Gallardo's field book of Chilean mammals. Bruce Patterson's critical reading added polish and clarity to the completed manuscript, and three anonymous reviewers en- hanced its quality. Financial support for the survey of neotropical mammals was received from the Barbara E. Brown Mammal Research Fund.

\section{Addendum}

The important contribution by Szalay (1994) on the evolution of marsupials came to my attention too late for critical examination here. It seems also that Szalay became aware of my (Hershkovitz, 1992a) paper on marsupial tarsal bones and rejection of his (1982b) classification based on them too late for consideration in his book beyond a perfunctory reference thereto (p. 63). Although of doubtful value here, Szalay's work may be useful for my monograph (in preparation) on New World marsupials.

\section{Gazetteer of Selected Collecting Localities from Maps (Fig. 19)*}

Antillanca, Puyehue, 4040/7209, 970 m, Osorno. Beatriz, Lago Nahuel Huapí, 4058/7130, 800 m, Neuquén, Argentina.

Carmen, Puerto, 4308/7346, sea level, Isla Chiloé. Cayutué, 4114/7217, $250 \mathrm{~m}$, Llanquihue.

Chiloé, 4230/7355, $700 \mathrm{~m}$, Isla Chiloé.

Colorado, Río, Llanquihue.

Colorado, Río, ca. 3825/7130, 900 m, Malleco.

Concepción, 3650/7303, 9 m, Concepción.

Contao, Palena, Llanquihue.

Huemul, Nahuel Huapí, ca. 4055/7130, 767 m, Neuquén, Argentina.

Huite, Puerto, 4207/7326, Isla Chiloé.

Itata, Río, 3623/7252. Ñuble or Bíobío.

La Picada, Forest Preserve, 41/7230, $450 \mathrm{~m}$, Osorno.

Lota, 3705/7310, sea level, Concepción.

Locar, Lago, 4011/7130, Neuquén, Argentina.

Maicolpue, 4033/7346, 50-110 m, Osorno.

Madera, Puerto (Isla Victoria), ca. 4056/7133, ca. $800 \mathrm{~m}$, Neuquén, Argentina.

Nahuelbuta, Sierra, 3748/7304, 1440 m, Malleco.

Nahuel Huapí National Park, 4100/7130, Neuquén, Argentina.

Negro, Río, Llanquihue.

Nielol, Cerro, 3840/7238, Cautín.

* Unless indicated otherwise, all localities are Chilean. 
Osorno, Volcán, 4106/7230, Osorno.

Osorno, 4031/7309, Osorno.

Peulla, Lago Todos Los Santos, 4106/7202, ca. $200 \mathrm{~m}$, Llanquihue.

Puerto Montt, 4128/7257, Osorno.

Puyehue National Park, Lago Paraísa, 4048/7217, $950 \mathrm{~m}$. Osorno.

Quellón-Quellón (Puerto Quellón?), 4307/7337. sea level. Isla Chiloé.

Quellón, Río Yaldad, 4307/7344, Chiloé.

Seno Reloncaví, 4138/7245, Llanquihue.

Temuco, 3844/7236, 113 m, Cautín.

Todos Los Santos, Lago, 4106/7215, ca. 200 m, Llanquihue.

Unión, 4017/7305, 29 m. Valdivia.

Valdivia, 3948/7314, ca. sea level, Valdivia.

Victoria, 3813/7220, $351 \mathrm{~m}$, Malleco.

Victoria. Isla. 4056/7133. ca. 800 m. Neuquén, Argentina.

Villa Angostura, Neuquén, Argentina.

Yaldad, Río, 4307/7344, 1sla Chiloé.

\section{Literature Cited}

AMEGHINo, F. 1887. Enumeración sistemática de las especies de mamíferos fósiles coleccionados por Carlos Ameghino en los terrenos eocenos de la Patagonia austral depositados en el Museo de la Plata. Boletín Museo de la Plata. 1: 1-26.

- 1891. Nuevos restos de mamíferos fósiles descubiertos por Carlos Ameghino en el Eoceno inferior de la Patagonia austral. Especies nuevas, adiciones y correcciones. Revista Argentina Historia Natural, 1: 289-328.

. 1898. Sinopsis geológico-paleontológica. Segundo censo de la República Argentina. Buenos Aires. 1: $112-225$.

1902 (1902-1904). Premiére contribution à la connaissance de la faune mammalogique des couches à Colpodon. Boletín Academia Ciencias, Córdoba. 17: 5-70.

APLIN, K. P., AND M. ARCHER. 1987. Recent advances in marsupial systematics with a new syncretic classification, pp. xv-lxxii. In Archer, M., ed.. Possums and Opossums, vol. 1. Surrey Beatty \& Sons, Chipping Norton, New South Wales.

ARCHER, M. 1993. Evolution of Australian mammal fauna, pp. 8-9. Abstracts, Sixth Theriological Congress. University of New South Wales, Sydney, Australia.

Biggers, J. D. 1966. Reproduction in male marsupials, pp. 251-277. In Rowlands, 1. W., ed., Comparative Biology of Reproduction in Mammals. Symposium. Zoological Society of London, vol. 15.

Biggers, J. D.. R. F. S. Creed, and E. D. Delamater. 1963. Conjugated spermatozoa in American marsupials. Journal of Reproduction and Fertility, 6: 324.

Bond, M.. R. Pascual. M. Reguero. S. Santillana,
And S. Marenssi. 1990. Los primeros "ungulados" extinguidos Sudamericanos de la Antárctica. Ameghiniana, 26: 3-4.

Bown. T. M.. And J. G. Fleagle. 1994. New Colhuéhuapian and Santa Crucian Microbiotheriidae and Caenolestidac from Patagonian Argentina. Journal of Vertebrate Paleontology, 14(3): 18a (Abstract).

Cabrera, A. 1919. Genera Mammalium. Monotremata. Marsupialia. Museo Nacional de Ciencias Naturales. Madrid, 177 pp.

— 1958 (1957-1961). Catálogo de los mamíferos de America del Sur. Revista del Museo Argentino de Ciencias Naturales "Bernardino Rivadavia," 4: iv + $732 \mathrm{pp}$.

Carlini, A. A., R. Pasclial, M. A. Reguero, C. J. Scil.Lato-YarRe, E. P. TONnI, AND S. F. VizCaino. 1991. The first Paleogene land placental mammal from Antarctica; its paleoclimatic and biogeographical bearings. VIII Jornados Argentinas de Palcontología de Vertebrados. Resúmenes, 7-9 Mayo, 1991. La Riojá.

Cifelli. R. L. 1993. Early Cretaceous mammals from North America and the evolution of marsupial dental characters. Proceedings of the National Academy of Science. USA, 90: 9413-9416.

Collins, L. R. 1973. Monotremes and Marsupials: A Reference for Zoological Institutions. Smithsonian Institution Press, Washington. D.C.. 323 pp.

Cunningham, R. O. 1871. Notes on the Natural History of the Straits of Magellan and West Coast of Patagonia. Edinburgh, 517 pp.

Dettman. M. E. 1989. Antarctica: Cretaceous cradle of austral temperate rainforests. pp. 89-105. In Crane. J. A.. ed.. Origins and Evolution of the Antarctic Biota. The Geological Society Special Publications, no. 47. Geological Society, London.

Doktor. M.. A. Gażdzicki, A. Jerzmańska, S. J. PorębSKI, AND E. ZASTAWNIAK. 1996. A plant-and-fish assemblage from the Eocene La Meseta formation of Seymour Island (Antarctic Peninsula) and its environmental implications. In Gaździcki, A., ed., Palacontological results of the Polish Antarctic expeditions. Part II. Palaeontologia Polonica. 55: 127-146.

Dyzenchauz, F. J.. M. A. Barros, J. A. W. Kirsch, ANd O. A. REIG. 1993. Dromiciops australis: G-banding analysis reinforces its close association to Australian marsupials. p. 82. Abstracts. Sixth International Theriological Congress, University of New South Wales. Sydney, Australia.

ENDERs, R. K. 1937. Panniculus camosus and formation of the pouch in didelphids. Journal of Morphology, 61(1): 1-26.

-1966. Attachment, nursing and survival of young in some didelphids, pp. 195-203. In Rowlands. 1. W., ed.. Comparative Biology of Reproduction in Mammals. Symposium of the Zoological Society of London, no. 15.

Fernández. R., S. Berrios, and J. Pincheira. 1979. Position of the nucleolus within the nuclei of pachytene spermatocytes of Dromiciops australis and Marmosa elegans (Didelphoidea-Marsupialia). Experientia, 35: $1021-1023$.

Frakes, L. A.. J. L. Probst, and W. Ludwig. 1994. Latitudinal distribution of paleotemperature on land 
and sea from Early Cretaceous to Middle Miocene. Comptes Rendus de l'Académie des Sciences. Earth and Planetary Sciences, II, 318(9): 1209-1218.

Gallardo, M. H., and B. D. Patterson. 1987. An additional 14-chromosome karyotype and sex chromosome mosaicism in South American marsupials. In Patterson, B. D., and R. M. Timm, eds., Essays in Honor of Philip Hershkovitz. Fieldiana: Zoology, n.s., no. 39: $111-115$.

GeISER, F. 1994. Hibernation and daily torpor in marsupials: A review. Australian Journal of Zoology, 42: $1-16$.

Goin, F. J., And A. A. Carlini. 1995. An Early Tertiary microbiotheriid marsupial from Antarctica. Journal of Vertebrate Paleontology, 15(1): 205-207.

GoldFuss, G. A. 1809 (1809, 1812). Vergleichende Naturbeschreibung der Säugethiere. Waltherschen Kunstund Buchhandlung. Erlangen, Germany.

Grant, T. R., and P. D. Temple-Smith. 1987. Observations on torpor in the small marsupial Dromiciops australis (Marsupialia: Microbiotheriidae) from southern Chile, pp. 273-291. In Archer, M., ed., Possums and Opossums: Studies in Evolution. Surrey, Beatty and Sons, Chipping Norton, New South Wales.

Greer, J. K. 1965. Mammals of Malleco Province Chile. Publications of the Museum, Michigan State University, Biological Series, 3(2): 53-151.

Hayward, J. S., AND P. A. Lisson. 1992. Evolution of brown fat: Its absence in marsupials and monotremes. Canadian Journal of Zoology, 70: 171-179.

Hershkovitz, P. 1962. Evolution of Neotropical cricetine rodents (Muridae), with special reference to the phyllotine group. Fieldiana: Zoology, 46: 1-524.

. 1977. Living New World Monkeys (Platyrrhini) with an Introduction to Primates. University of Chicago Press, Chicago, xiv + 1117 pp.

-1 1982. The staggered marsupial lower third incisor $\mathrm{i}_{3}$. Geobios, Mémoire Special, 6: 191-200.

- 1992a. Ankle bones: The Chilean opossum Dromiciops gliroides Thomas, and marsupial phylogeny. Bonner Zoologische Beiträge, 43(2): 181-213.

1992b. The South American gracile opossums, genus Gracilinanus Gardner and Creighton, 1989 (Marmosidae, Marsupialia): A taxonomic review with notes on general morphology and relationships. Fieldiana: Zoology, n.s., 70: 1-56.

1995. The staggered marsupial third lower incisor: Hallmark of Cohort Didelphimorphia, and description of a new genus and species with staggered $\mathrm{i}_{3}$ from the Albian (Lower Cretaceous) of Texas. Bonner Zoological Beiträge, 45(3/4): 153-169.

1997. Composition of the family Didelphidae Gray, 1821 (Didelphoidea, Marsupialia) with a review of the morphology and behavior of the included genus Philander Tiedemann, 1808. Fieldiana: Zoology, n.s. 86: $1-103$.

Hume, 1. D. 1982. Digestive Physiology and Nutrition of Marsupials. Cambridge University Press, Cambridge.

HUNSAKER, D., II. 1977. Ecology of New World marsupials, pp. 95-155. In Hunsaker, D., II, ed., The Biology of Marsupials. Academic Press, New York.
JimÉNEZ, J., AND R. RAgeOT. 1979. Notas sobre la biología del monito del monte. Anales del Museo de Historia Natural. Valparaiso, Chile, no. 12: 83-88.

Kirsch, J. A. W., A. W. Dickerman, O. A. Reig, AND M. S. Springer. 1991. DNA hybridization evidence for the Australian affinity of the American marsupial Dromiciops australis. Proceedings of the National Academy of Science, USA, 88: 10465-10469.

KIRSCH, J. A. W., AND P. F. WALlER. 1979. Notes on the trapping and behavior of the Caenolestidae. Arkiv Zoologie, 14: 1-104.

KrIEG, H. 1925. Biologische Reisestudien in Südamerika. Chilenische Beutelratten. Zeitschrift für Morphologie und Ökologie, 3: 169-176.

Krumbiegel, I. 1941. Die Säugetiere der SüdamerikaExpeditionen Prof. Dr. Kriegs. Zoologischer Anzeiger, 135(1/2): $1-12$.

LYNE, A. G. 1959. The systematic and adaptive significance of the vibrissae in the Marsupialia. Proceedings of the Zoological Society of London, 133(1): 79-132.

ManN, G. 1955. Monito del monte Dromiciops australis Philippi. Investigaciones Zoológicas Chilenas, 2(9/10): 159-166.

- 1958. Reprodución de Dromiciops australis (Marsupialia, Didelphydae). Investigaciones Zoológicas Chilenas, 4: 209-213.

1978. Los pequeños mamíferos de Chile. Gayana Zoología, 40: 1-342.

Marshall, L. G. 1978. Dromiciops australis. Mammalian Species, 99: 1-5.

1982. Systematics of the South American marsupial family Microbiotheriidae. Fieldiana: Geology, n.s., 10: vii $+1-75$.

. 1987. Systematics of Itaboraian (Middle Paleocene) age "opossum-like" marsupials from the limestone quarry at São José de Itaboraí, Brazil, pp. 91-160. In Archer, M., ed., Possums and Opossums: Studies in Evolution. Surrey, Beatty and Sons, Chipping Norton, New South Wales.

Marshall, L. G., J. A. Case, and M. O. Woodburne. 1990. Phylogenetic relationships of the families of marsupials, pp. 433-505. In Genoways, H. H., ed., Current Mammalogy 2. Plenum Press, New York.

Marshall, L. G., And C. DE Muizon. 1988. The dawn of the age of mammals in South America. National Geographic Research, 4(1): 23-55.

Marshall, L. G., and C. DE Muizon. 1995. Part 1I: The skull. In Muizon, C. de, ed., Pucadelphys andinus (Marsupialia, Mammalia) from the early Paleocene of Bolivia. Memoires du Muséum National d'Histoire Naturelle, Paris, 165: 21-90.

Marshall, L. G., C. DE Muizon, M. Gayet, A. Lavenu, AND B. SIGÉ. 1985. The "Rosetta Stone" for mammalian evolution in South America. National Geographic Research, 1: 274-288.

Marshall, L. G., C. de Muizon, and D. SigogneauRussell. 1995. Pucadelphys andinus (Marsupialia, Mammalia) from the early Paleocene of Bolivia. Memoires du Museum National d'Histoire Naturelle, 165: $1-164$.

Meserve, P. L., B. K. Lang, and B. D. Patterson. 1988. Trophic relationships of small mammals in a 
Chilean temperate rain forest. Journal of Mammalogy, 69(4): 721-730.

NorRIS, C. A. 1993. Changes in the composition of the auditory bulla in southern Solomon Islands populations of the gray cuscus, Phalanger orientalis breviceps (Marsupialia, Phalangeridae). Zoological Journal of the Linnaean Society, 107(2): 93-106.

Oliver Schneider, C. 1946. Catálogo de los mamíferos de la provincia de Concepción. Boletín de la Sociedad de Biología de Concepción, Chile, 21: 67-83.

OsGood, W. H. 1943. The mammals of Chile. Field Museum of Natural History, Zoological Series, 30: 1319.

Pascual, R., M. Archer, E. Ortiz Juareguizar, J. L. Prado, H. Godthelp, and S. J. Hand. 1992a. First discovery of monotremes in South America. Nature, 356: 704-705.

Pascual, R., M. Archer, E. Ortiz Juareguizar, J. L. Prado, H. Godthelp, and S. J. Hand, 1992b. The first non-Australian monotreme: An early Paleocene South American Platypus (Monotremata, Ornithorhynchidae). In Augee, M. L., ed., Platypus and Echidnas. Royal Zoological Society of New South Wales, Sydney, Australia.

Pascual, R., AND E. O. Juareguizar. 1990. Evolving climates and mammal faunas in Cenozoic South America. Journal of Human Evolution, 19(1/2): 2360.

PAtTerson, B. 1956. Early Cretaceous mammals and the evolution of mammalian molar teeth. Fieldiana: Geology, 13(1): 1-105.

Patterson, B. D., and M. H. Gallardo. 1987. Rhyncholestes raphanurus. Mammalian Species, 286: I-5.

Patterson, B. D., P. L. Meserve, and B. K. Lang. 1989. Distribution and abundance of small mammals along an elevational transect in temperate rain forests of Chile. Journal of Mammalogy, 70(1): 67-78.

Patterson, B. D., P. L. Meserve, and B. K. Lang. 1990. Quantitative habitat associations of small mammals along an elevational transect in temperate rainforests of Chile. Journal of Mammalogy, 71(4): 620633.

Paula-Couto, C. DE. 1962. Didelfideos fósiles del Paleoceno de Brazil. Revista Museu Argentino Ciencias Naturales "Bernardino Rivadavia," Zoología, 8(12): 135-166.

Pearson, A. K., O. P. Pearson, and 1. A. Gomez. 1994. Biology of the bamboo Chusquea culeou (Poaceae: Bambusoideae) in southern Argentina. Vegetatio, 3: 93-126.

PEARSON, O. P. 1983. Characteristics of a mammalian fauna from forests in Patagonia, in southern Argentina. Journal of Mammalogy, 64(3): 476-492.

Pearson, O. P. and A. K. Pearson. 1982. Ecology and biogeography of the southern rainforests of Argentina, pp. 129-142. In Mares, M. A., and H. H. Genoways, eds., Mammalian Biology in South America. Special Publication Series, Pymatuning Laboratory of Ecology, University of Pittsburgh.

Philippl, F. 1893a. Ein neues Beutelthier Chiles. Verhandlungen Deutsches Wissenschaft. Vercin, Santiago de Chile, 5: 318-319. la Universidad de Chile, 85: 31-34.

Philippi, R. A. 1894. Ein neues Beuteltier Chiles. Archiv für Naturgeschichte, 1(1): 33-35.

Pridmore, P. A. 1994. Locomotion in Dromiciops australis (Marsupialia: Microbiotheriidae). Australian Journal of Zoology, 42: 679-699.

REIG, O. A. 1955. Noticia preliminar sobre la presencia de mierobiotherinos en la fauna Sudamericana. Investigaciones Zoológicas Chilenas, 2(8): 121-129.

Reig, O. A., R. Fernandez, and O. A. Spotorno. 1972. Further occurrence of a karyotype of $2 n=14$ chromosomes in two species of Chilean didelphoid marsupials. Zeitschrift für Säugctierkunde, 37(I): 37-42.

Reig, O. A., A. L. Gardner, N. O. Bianchi, and J. L. Patton. 1977. The chromosomes of the Didelphidae (Marsupialia) and their evolutionary significance. Biological Journal of the Linnaean Socicty, 9: 191-216.

Retief, J. K., C. Krajewski, M. Westerman, R. H. Winkfein, AND G. H. Dixon. 1995. Molecular phylogeny and evolution of marsupial protamine Pl genes. Proceedings of the Royal Society of London (B), 259: 7-14.

Rodger, J. C. 1982. The testis and its excurrent ducts in American caenolestid and didelphid marsupials. American Journal of Anatomy, 163: 269-282.

Romer, A. F. 1966. Vertebrate Paleontology, 3rd edition. University of Chicago Press, Chicago.

Rosenmann, M., AND R. Ampuero. 1981. Hibernación en Dromiciops australis. Archivos de Biología y Medicina Experimentales (Santiago de Chile), 14: 294 (Abstract).

Santos, J. G. 1946. La comadrejita enana Dromiciops australis australis (F. Philippi). Holmbergia, 4: 191195.

Segall, W. 1969. The middle ear region of Dromiciops. Acta Anatómica, 72: 489-501.

SEWARD, A. C. 1914. Antarctic fossil plants. British Antaretica ("Terra Nova") Expedition 1910. Natural History Reports, Geology, London, 1(1): 1-49.

Sharman, G. B. 1973. The chromosomes of non-eutherian mammals, pp. 485-530. In Chiarelli, A. B., and E. Capanua, eds., Cytotaxonomy and Vertebrate Evolution. Academic Press, London.

- 1982. Karyotypic similarities between Dromiciops australis (Microbiotheriidae, Marsupialia) and some Australian marsupials, pp. 711-721. In Archer, M., ed., Carnivorous Marsupials, vol. 2. Royal Zoological Society of New South Wales, Sydney, Australia.

Simpson, G. G. 1964. Los mamíferos Casamayorenses de la colección Tounnouër. Revista Museu Argentino Ciencias Naturales "Bernardino Rivadavia." Paleontología, 1: 1-21.

Sinclair, W. J. 1906. Marsupialia, pp. 333-460. In Reports of the Princeton University Expeditions to Patagonia 1896-1899. Vol. IV, Paleontology 1, Part III: Mammalia of the Santa Cruz Beds, pls. XL-LXV. Princeton University, Princeton, N.J.

Slaughter, B. H. 1968a. Earliest known marsupials. Science, 162: 254-255. 
1968b. Holoclemensia instead of Clemensia. Science, 162: 1306.

Spotorno, O. A., AND D. R. Fernández. 1971. The chromosomes of the "monito del monte," Dromiciops australis Philippi. Mammalian Chromosome Newsletter, $12(2)$ : $40-41$.

Springer, M. S., J. A. W. Kirsch, And J. A. Case. 1996. The chronicle of marsupial evolution. I $n$ Givnish, T. J., and K. J. Sytsma, eds., Molecular Evolution and Adaptive Radiation. Cambridge University Press. Cambridge (in press).

Springer, M. S., M. Westerman, and J. A. W. Kirsch. 1994. Relationships among orders and families of marsupials based on $12 \mathrm{~S}$ ribosomal DNA sequences and the timing of the marsupial radiation. Journal of Mammalian Evolution, 2: 85-1 15.

Szal.Ay, F. S. 1982a. Phylogenetic relationships of the marsupials. Geobios Mémoire Spécial, 6: 177-190.

1982b. A new appraisal of marsupial phylogeny and classification, pp. 621-640. In Archer, M. ed., Carnivorous Marsupials, vol. 2. Royal Zoological Society of New South Wales, Sydney, Australia.

1994. Evolutionary History of the Marsupials and an Analysis of Osteological Characters. Cambridge University Press, Cambridge.

Tamayo, H. M., and C. Frassinetti. 1980. Catálogo de los mammíferos fósiles y vivientes de Chile. Boletín Museo Nacional de Chile, 37: 323-399.

TEMPle-Smith, P. 1987. Sperm structure and marsupial phylogeny, pp. 171-193. In Archer, M., ed., Possums and Opossums: Studies in Evolution, vol. 1. Surrey Beatty \& Sons, Chipping Norton, New South Wales.

Thomas, O. 1894. On Micoureus griseus, Desm. with the description of a new genus and species of Didelphidae. Annals and Magazine of Natural History, series 6, 14: 184-188.

1919. On small mammals collected by Sr. E. Budin in northwestern Patagonia. Annals and Magazine of Natural History, series 9, 3: 199-212.

Tribe, C. J. 1990. Dental age classes in Marmosa incana and other didelphoids. Journal of Mammalogy, 71(4): 566-569.

Trouessart, E.-L. 1898. Catalogus mammalium tam viventium quam fossilium fasc. 5. Friedlander and Sohn, Berlin.

TuRnbull, W. D. 1995. Trinity mammal jaws from the late Early Cretaceous of North Texas, pp. 266-269. In Linsky, R. J., and H. Renz, eds., Proceedings, 10th International Symposium of Dental Morphology, Berlin.

Tyndale-Biscoe, H., And M. Renfree. 1986. Reproductive physiology of marsupials. Cambridge University Press, Cambridge.

WESTERMAN, M., AND D. EDWARDS. The relationship of Dromiciops australis to other marsupials: Data from DNA-DNA hybridisation studies. Australian Journal of Zoology, 39: 123-130.

Wolffsohn, J. A., And C. E. Porter. 1908. Catálogo metódico de los mamíferos Chilenos existentes en el Museo de Valparaiso en Diciembre de 1905. Revista Chilena de Historia Natural, 12(1): 66-85.

Woodburne, M. O., and J. A. CAse. 1996. Dispersal. vicariance, and the Late Cretaceous to Early Tertiary land mammal biogeography from South America to Australia. Journal of Mammalian Evolution, 3(2): $121-161$.

Woodburne, M. O., And W. J. Zinsmeister. 1984. The first land mammal from Antarctica and its biogeographic implications. Journal of Paleontology, $\mathbf{5 8}(4)$ : 913-948.

WoOlley, P. A. 1974. The pouch of Planigale subtilissima and other dasyurid marsupials. Journal of the Royal Society of Western Australia, 57(1): 11-15.

1987. The seminiferous tubules, rete testis and efferent ducts in didelphid, caenolestid and microbiotheriid marsupials, pp. 217-227. In Archer, M., ed. Possums and Opossums, vol. 1. Surrey Beatty \& Sons and Royal Zoological Society of New South Wales Chipping Norton, New South Wales.

ZINSMEISTER, W. J. 1976. Biogeographic significance of the Late Mesozoic and Early Tertiary molluscan fau. nas of Seymour Island (Antarctica Peninsula) to the final breakup of Gondwanaland, pp. 349-355. I Gray, J., and A. Boucot, eds.. Historical Biogeography, Plate Tectonics and the Changing Environment Proceedings, 37th Annual Biological Colloquium anc Selected Papers. Oregon State University Press, Cor vallis. 




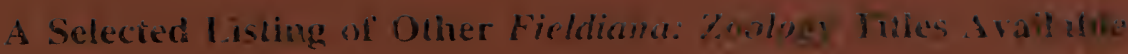

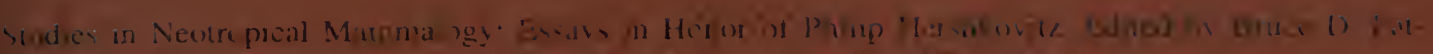

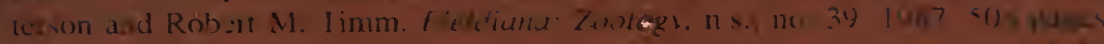

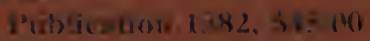

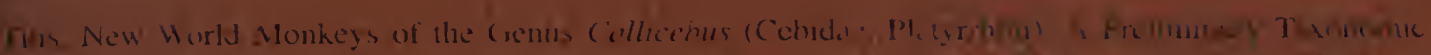

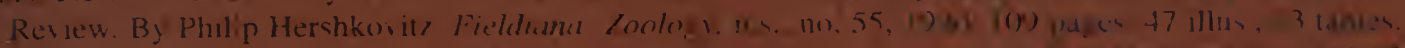

Jublication 1419), 423.(6)

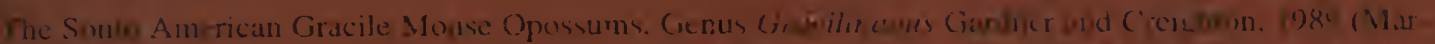

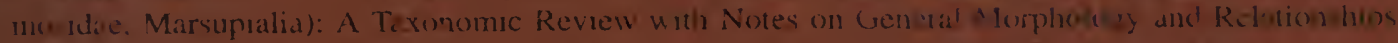

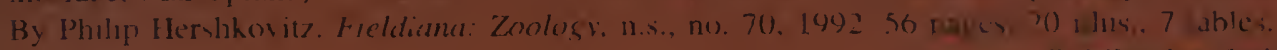

Putlication $1+11, \$ 17.00$

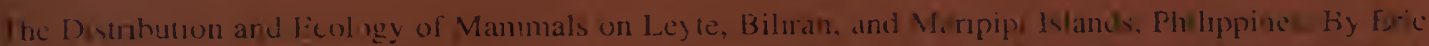

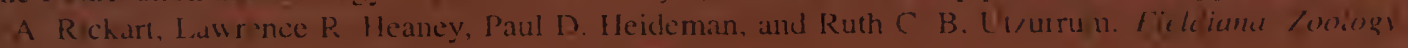
nᄂ. no 72. 1993. 62 pages, 18 illus. 20 iables

Publication $14+19, \$ 18.00$

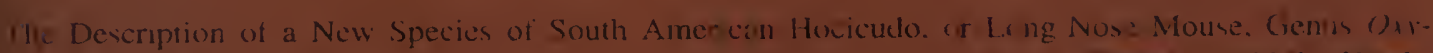

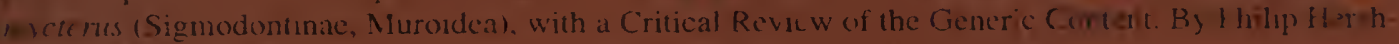
husit7. F cleliana Zon'ogv, n.s.. no. 79, 1994. 43 pages, 21 1lluk.. 2 tahles.

Rublication 1460, \$13.00)

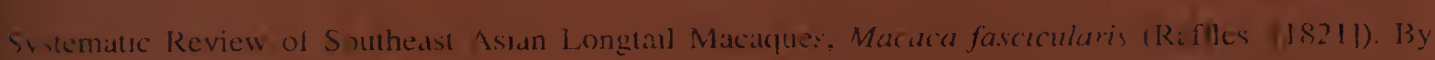
Jach Foxuson. Fieldana: Loology, n..., no. 81. 1995. 206 pages. 31 illus.. 30 tables.

Publication 1470. \$35.(1)

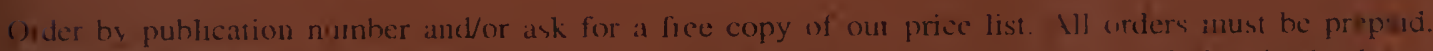

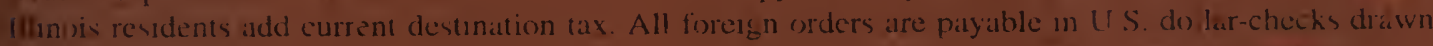
." any U.S bank or the (I S. subsidiary of any foreign bank. Prices and terns subjoct to cha loe w uhout motice. Address all requents to:

\section{TIEI D MUSLL M OF NATURAL HISIORI}

Library--Publications Divisisn

Rooserelt Road at Lake Shore Drive

(Chicago, lllinuis $(x) 605-2498$, I i. A 


